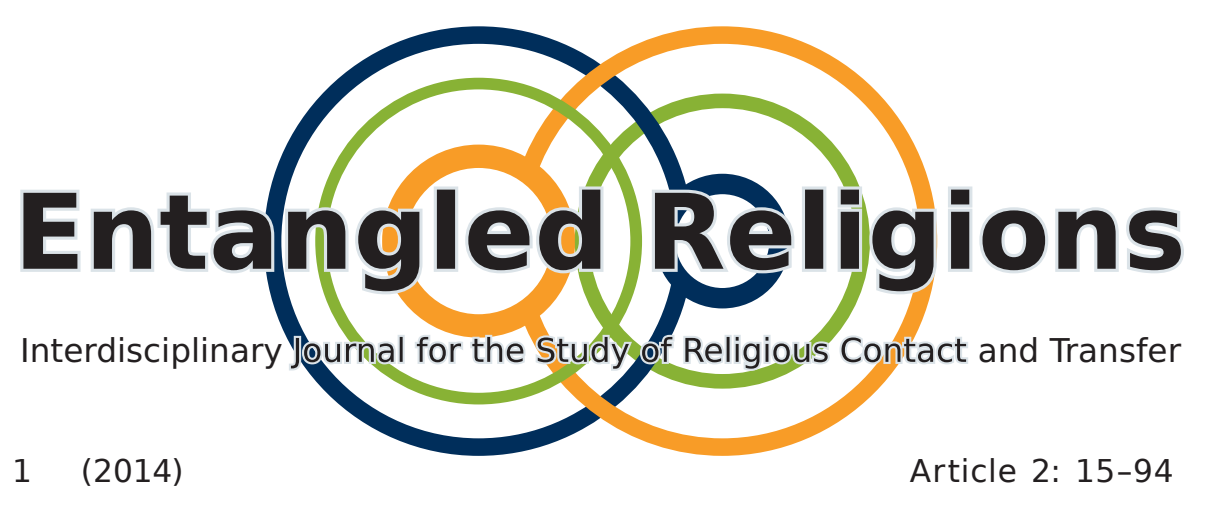

\title{
The Figure with a Bow in Gandhāran Great Departure Scenes.
}

\section{Some New Readings}

JESSIE PONS

Ruhr-Universität Bochum, Käte Hamburger Kolleg "Dynamics in

the History of Religions between Asia and Europe", Germany

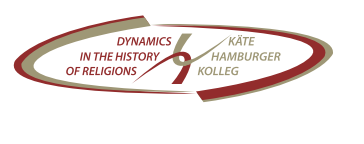




\title{
The Figure with a Bow in Gandhāran Great Departure Scenes.
}

\author{
Some New Readings
}

JESSIE PONS

Ruhr-Universität Bochum

\begin{abstract}
The figure holding a bow on Gandhāran illustrations of the Bodhisattva's departure from Kapilavastu has been the subject of controversy. First identified as Māra and Indra, the interpretation proposed by $\mathrm{K}$. Tanabe that the protagonist is VaiśravanaKubera rallied broader consensus. The present reassessment takes into account the multicultural and multi-religious context of production of the images, namely the Kushan era, to offer additional readings of the Gandhāran figure. The approach is two-fold. The examination of written and visual traditions of representing the episode is complemented by the analysis of the Gandhāran iconography in light of material from various cultural strands which came into contact in the region. As a final step, the article considers possible logics which might have constrained the construction of the Gandhāran portrayals and tests the hypothesis that further divinities from religious trends coeval in Gandhāra may be recognized under the guises of the bow-holder.
\end{abstract}

KEY WORDS Gandhāra, Buddhist iconography, great departure, Vaiśravaṇa-Kubera, multiple identities, Kushan era

After having renounced the pleasures of the princely life at the age twentynine, Siddhārtha Gautama summons his servant Chandaka to prepare his horse for departure. The latter vainly tries to dissuade his master from leaving the palace and Siddhārtha mounts his horse Kaṇțhaka, ready to set off for the religious life. Divinities coming from all sides facilitate his escape. They sink the inhabitants of the palace into a deep sleep, lift up the horse's hooves and, having opened the city of Kapilavastu's heavy door, they rejoice at the Bodhisattva's departure. 
Here summarized in its basic outline, the abhinișkramana, the 'renunciation' or 'great departure,' is, along with his birth, the most popular episode of Siddhārtha Gautama's biography in Gandhāran Buddhist art. The Bodhisattva is commonly shown in profile astride his horse Kaṇțaka whose hooves are lifted by yakșas (genies), exiting the gates of Kapilavastu and passing left. A chattra (umbrella) bearer traditionally identified as his groom Chandaka is placed at the croup of the horse or by its right side and

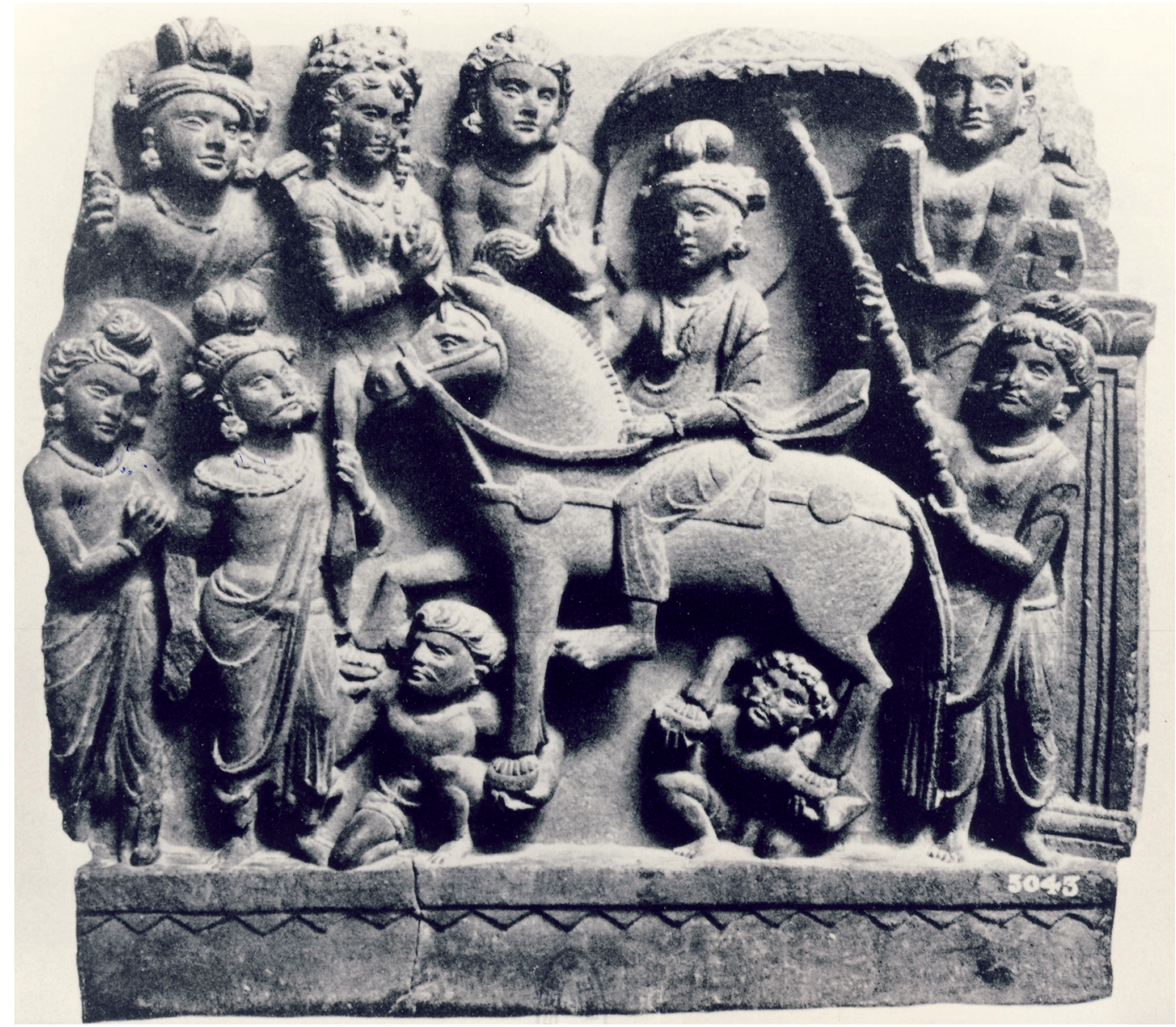

FIGURE 1 Great Departure, relief from Loriyān Tāngai, India Museum, Calcutta (๔) Archives Madame Tissot, UMR 8546) 
a figure holding a bow invariably precedes the rider. On many examples, Siddhārtha is escorted by a group of devas (deities) (fig. 1). ${ }^{1}$

This paper focuses on the iconography of the figure holding a bow which has aroused much debate. He carries the weapon in the left hand and the right hand is most frequently extended but is sometimes holding an arrow. By this attitude, he seems to both guide and protect the Bodhisattva. The portrayal of the protagonist follows five main fashions. The figure is:

1. dressed in a paridhāna (a piece of clothing wrapped around the waist) ${ }^{2}$ an uttariya (a shawl) and a turban. The latter is worn either centrally (fig. 2) or sideways ([fig. 3] Spooner 1910, 11-12 and 57-58; Ingholt 1957, no. 45). Variants without the uttarīya also exist (Ackermann 1975, 70-71 pl. XIV; Kurita 2003, 1: no. 475),

2. wearing a long-sleeved tunic and baggy trousers ([fig. 4] Dobbins 1973, fig. 42),

3. shown with a short tunic and no lower garment. The tunic might be short-sleeved ([fig. 5] Ingholt 1957, no. 168) or long-sleeved ([fig. 6] Dagens 1964, 16 pl. Ill-9; Tanabe 2000, 1088 fig. 1) and tied around the waist. On the relief from Nimogram ([fig. 7] Kurita 1988, pl.2-l; Tanabe 1997-1998, 227 figs. 2 and 3), a mantle completes the garment. In most cases the headdress is winged,

1 This type of composition is the most popular and is used on three different media: frieze reliefs, harmikā (the upper-structure on a stūpa) and pedestals. Out of the hundred-three illustrations recorded within the framework of a doctoral research on Gandhāran Buddhist art (Pons 2011), fifty-nine display this composition. The other type of composition, discussed below, is essentially found on false niches (thirty-three examples) and depicts the Bodhisattva astride his horse in foreshortening, as though he was appearing towards the observer.

2 In most cases (see for instance fig. 3), the paridhāna is pulled up between the legs (dhotī). 


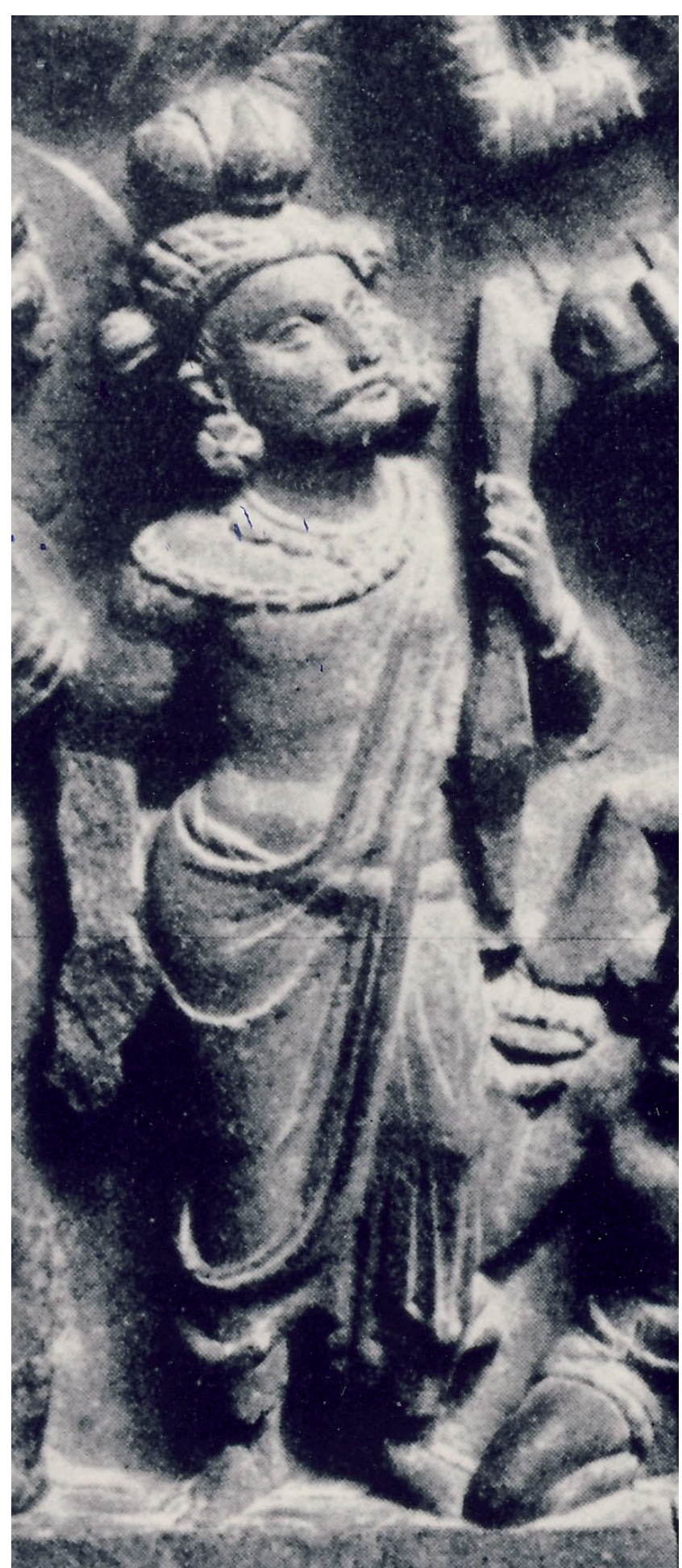

FIGURE 2

Type 1, with turban worn centrally (detail of fig. 1 ) 
The Figure with a Bow in Gandhāran Great Departure Scenes.

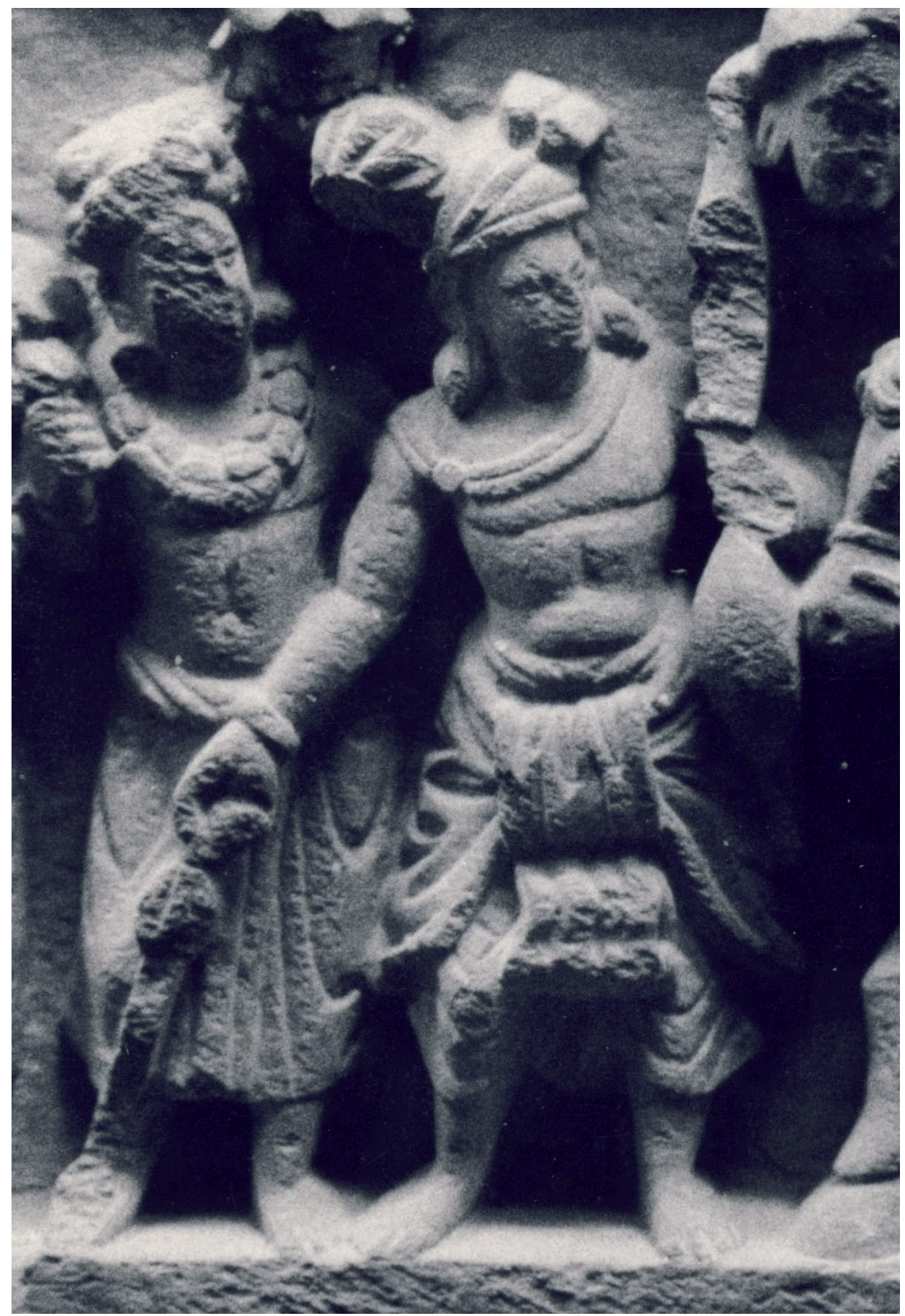

$\oplus$

FIGURE 3

Type 1, with turban worn sideways, detail of a relief from Sahrī Bāhlol, Governmental Museum, Peshawar (@ Archives Madame Tissot, UMR 8546) 


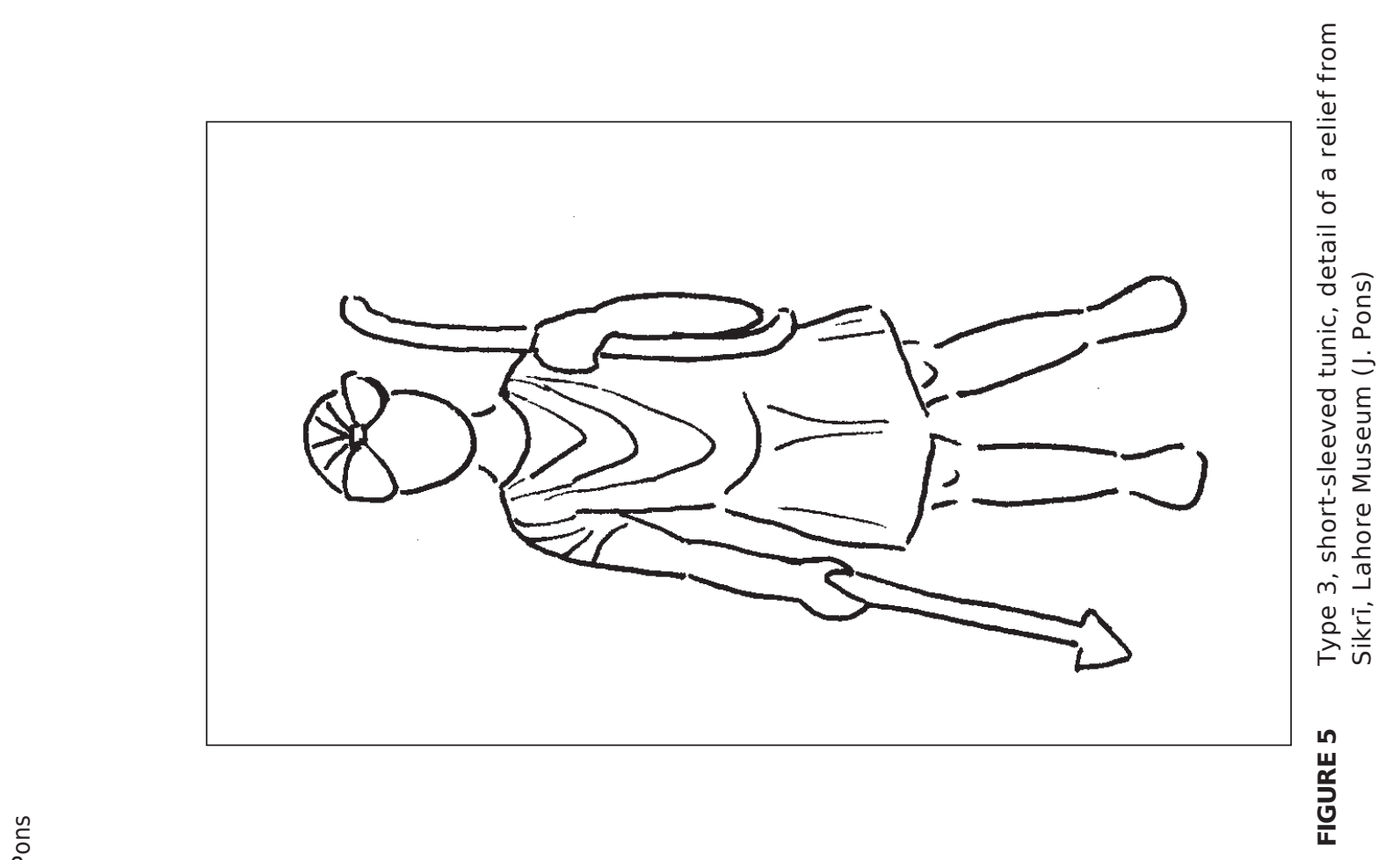

국

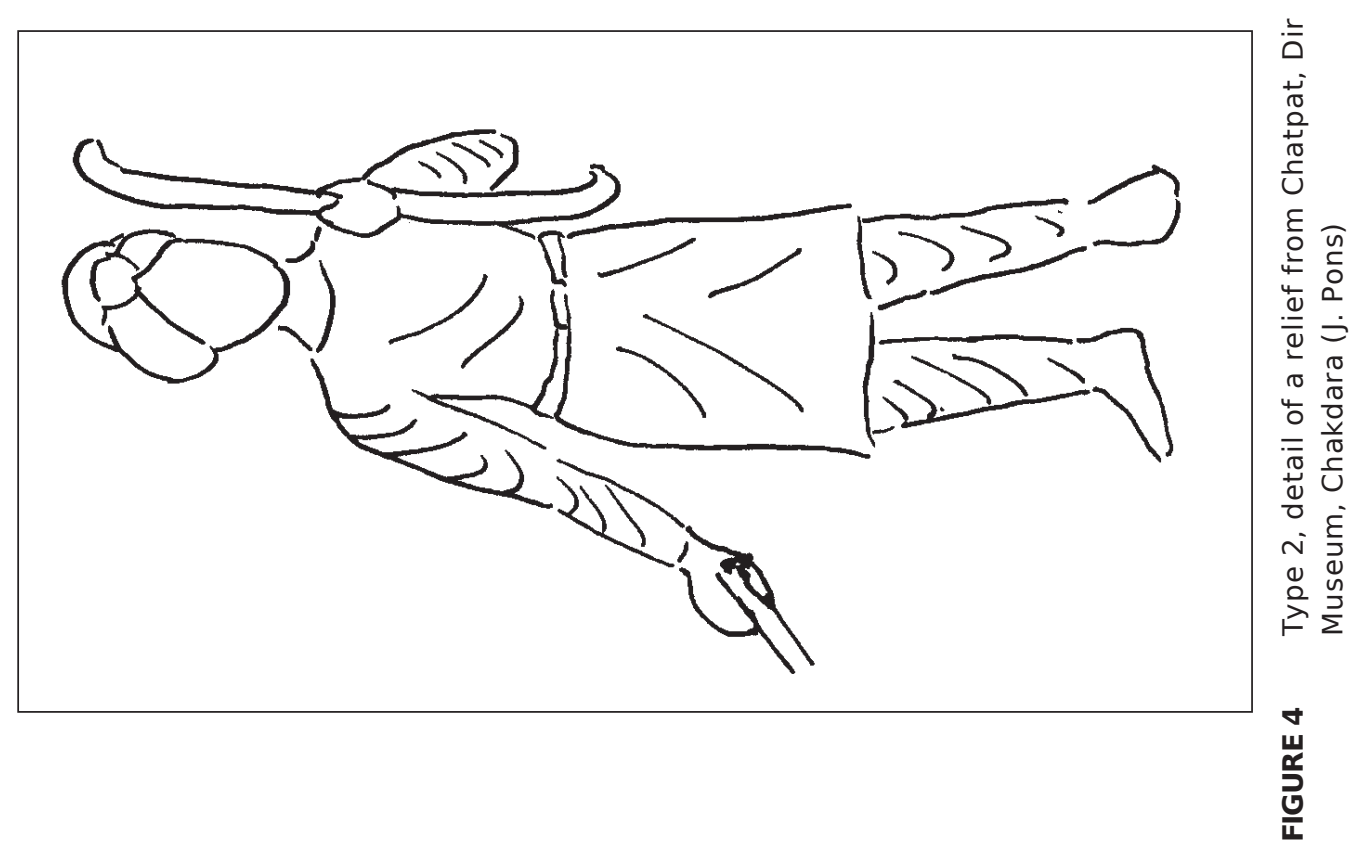




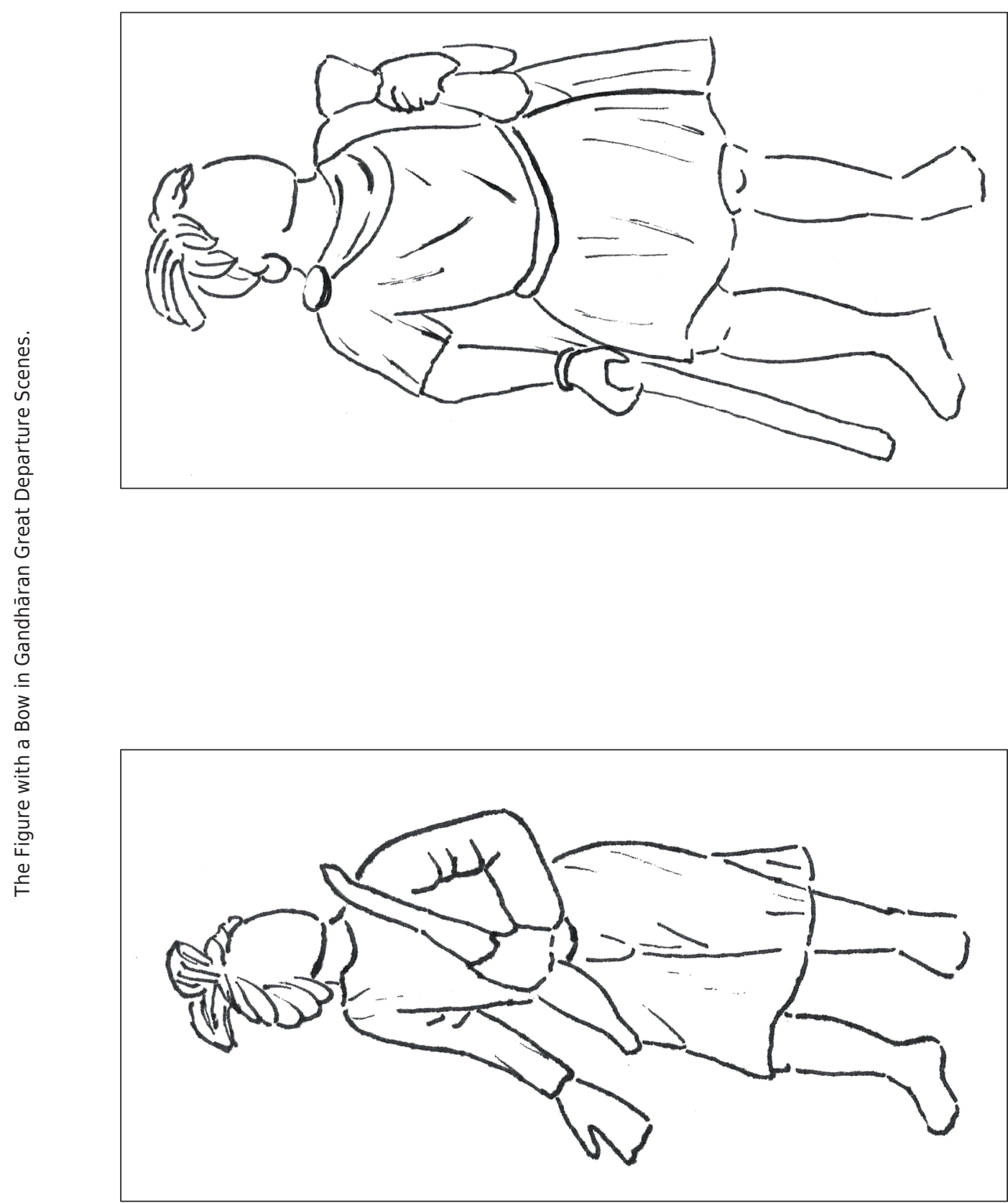

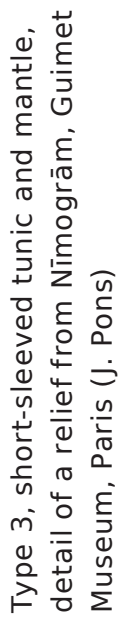

矛

$\approx$

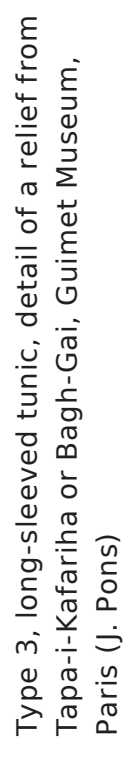

$\oplus$

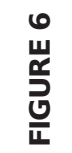




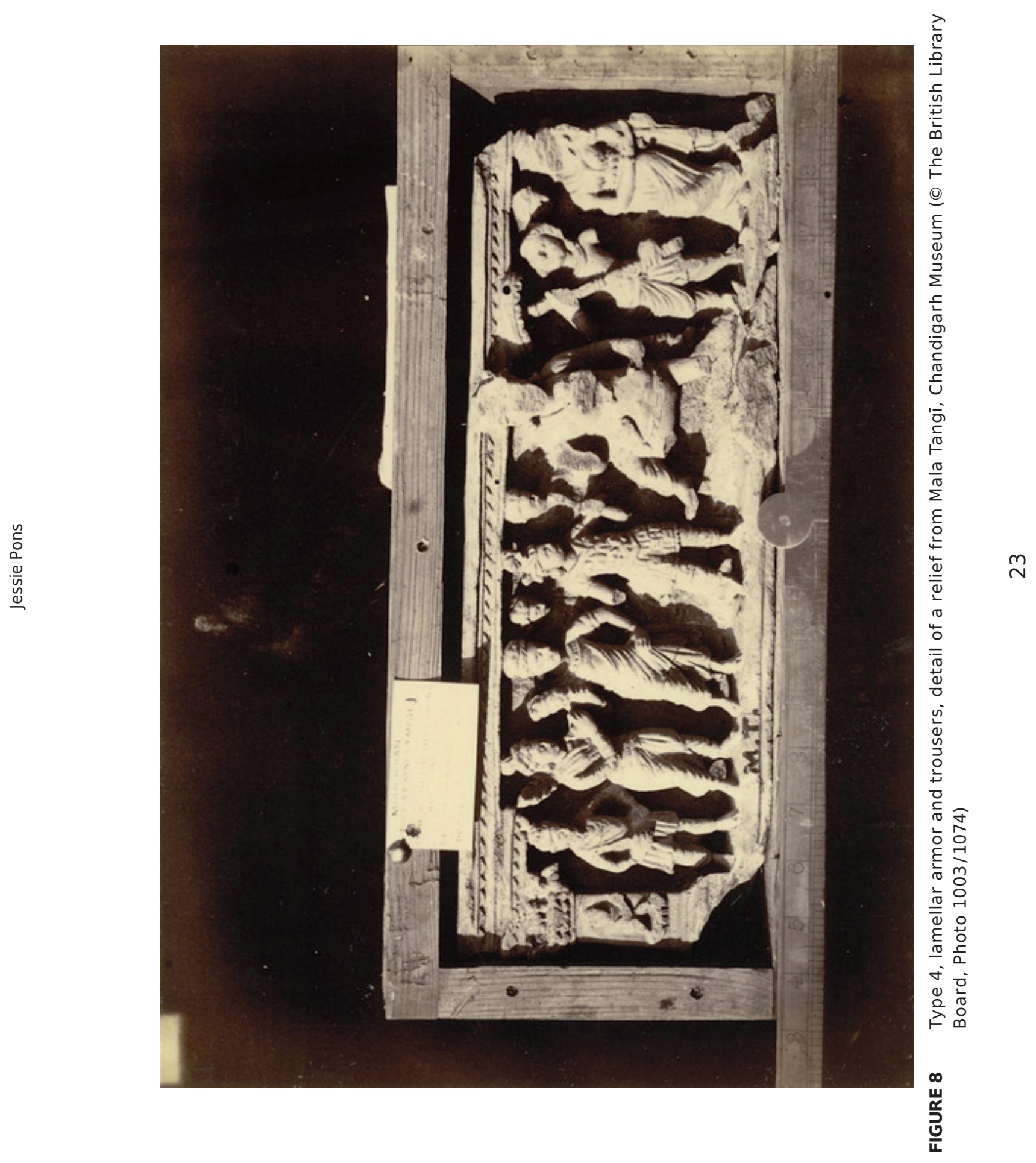

(†) 
4. depicted as a warrior, carrying a lamellar type armor (cataphractus). Two main variants can be observed: wearing trousers (fig. 8) and wearing a dhotī (fig. 9). ${ }^{3}$ The figure might display a turban worn centrally or a winged headdress (fig. 10),

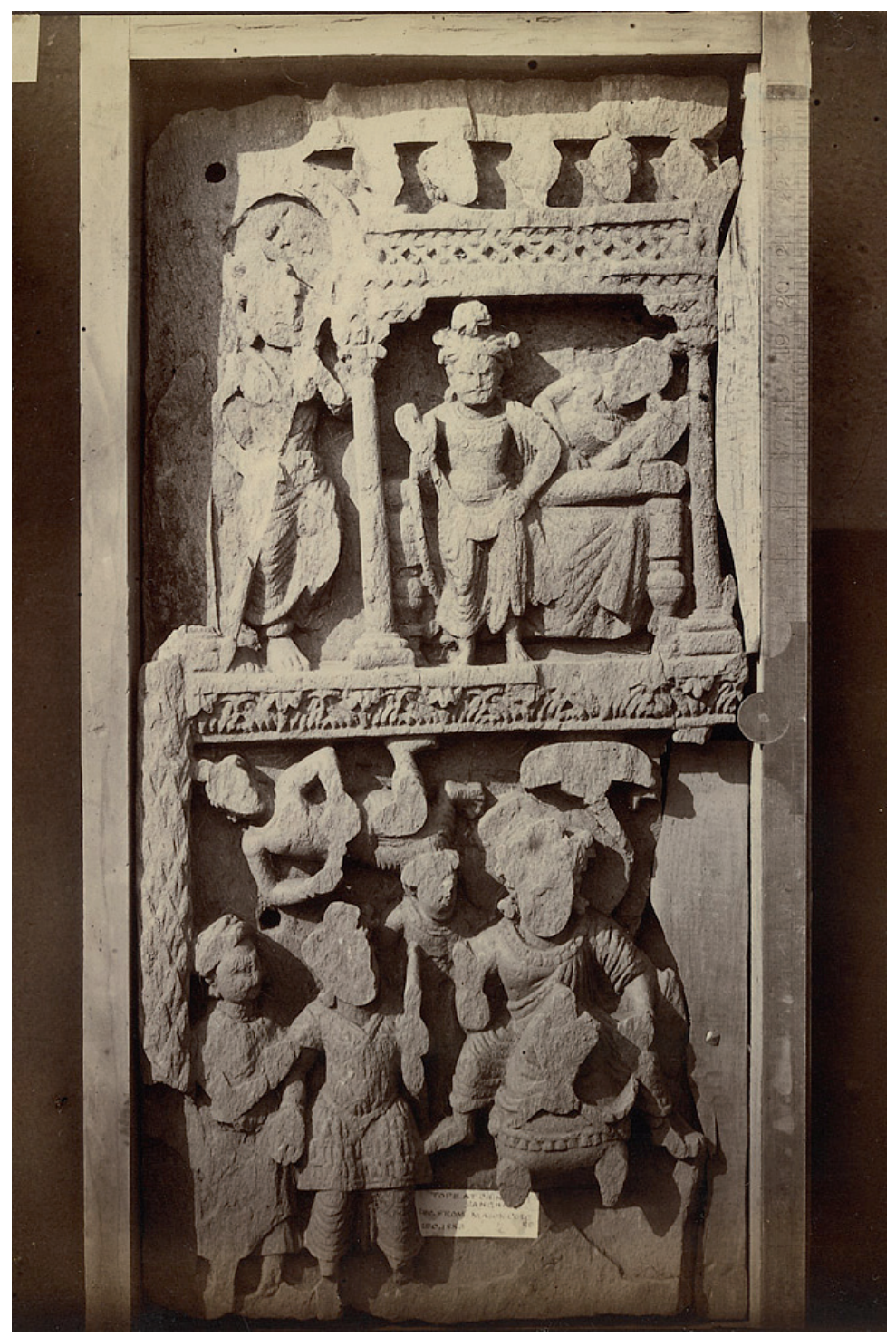

\section{FIGURE 9}

Type 4, lamellar armor and dhotī, detail of a relief from Sanghao or Chinglai, Lahore Museum (৫) British Library Board, Photo 1003/1116)

3 For another example see Faccenna 1962, II-2: 29 pl. 91. 

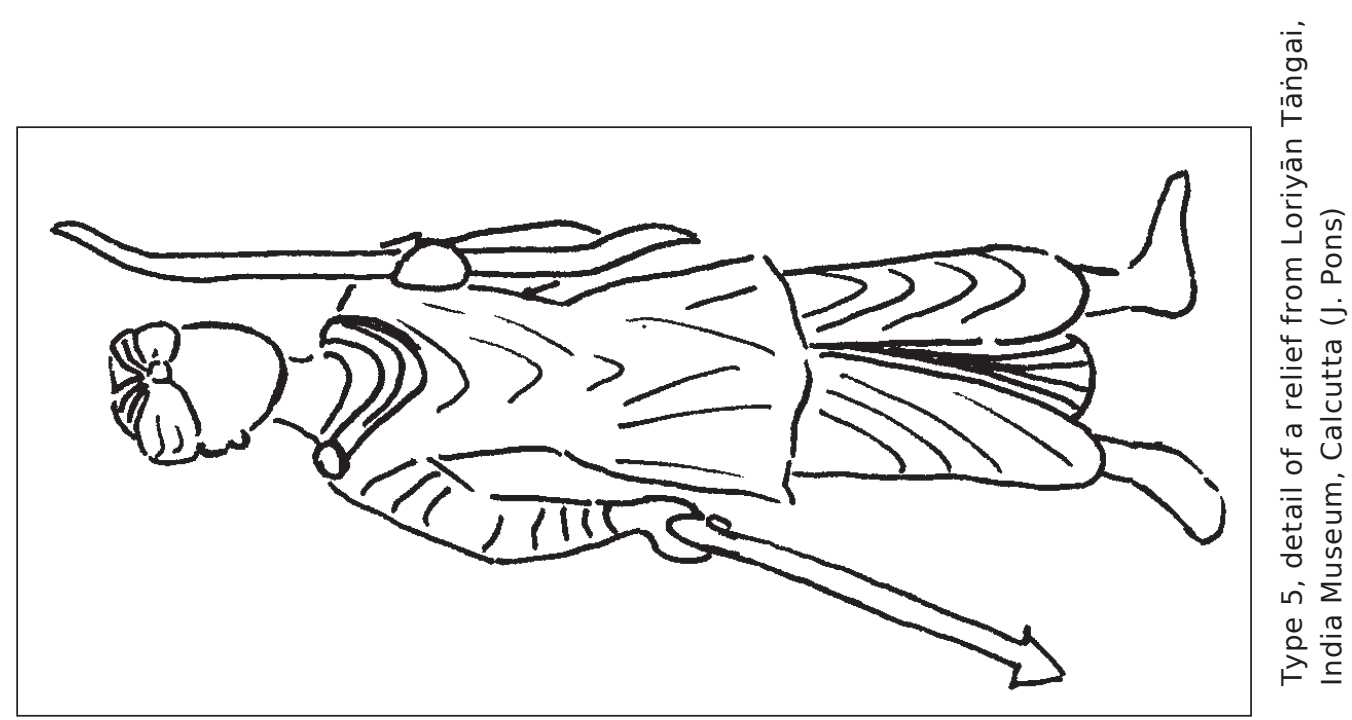

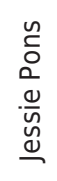

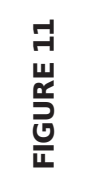

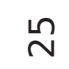

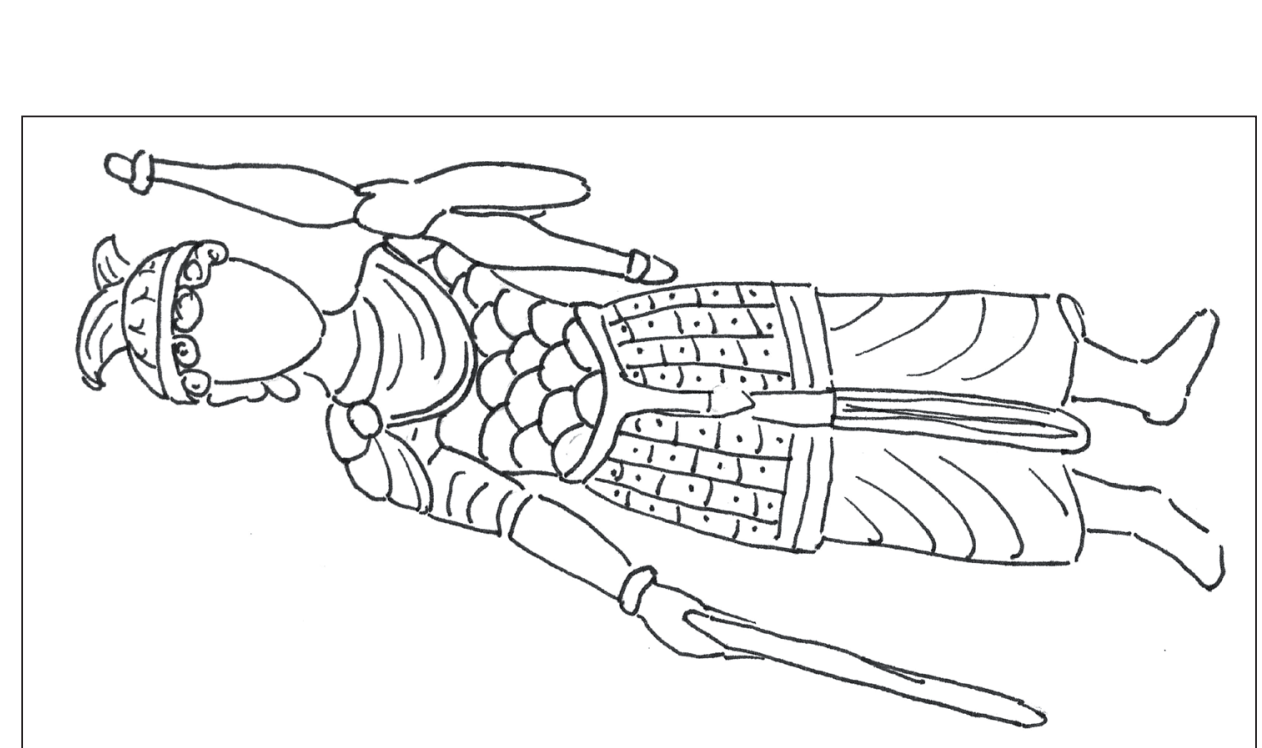

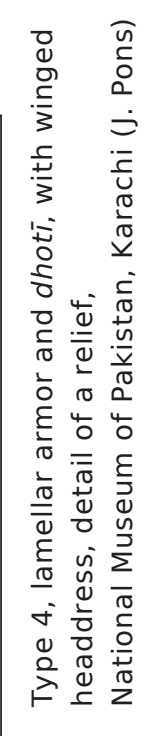

온
w్
돈
는 
The Figure with a Bow in Gandhāran Great Departure Scenes.

5. wearing a dhotī, a long sleeved tunic and, on all the examples of this type, a turban. On several reliefs, he is clad in a mantle ([fig. 11] Sengupta and Das 1991, 38 no. 369).

Since the beginning of the twentieth century, several identifications have been proposed for the protagonist: Māra, ${ }^{4}$ Indra ${ }^{5}$ and Vaiśravaṇa-Kubera. ${ }^{6}$

4 This identification has been suggested by A. Foucher (Foucher 1905-1951, 1: 356357). A. Foucher finds in the Nidānakathā and in the Buddhacarita the justification for his interpretation. The Nidānakathā reports that Māra actively attempts to divert the Bodhisattva from his endeavor (Dutoit 1921, 14-15). As for the Buddhacarita, it describes Māra as the god of love (Buddhacarita 13.2; Olivelle 2009, 373). The attributes held by Māra, the bow and arrow, would subsequently be borrowed from his Brahmanic counterpart: Kāma. Several authors have agreed on this interpretation (Ingholt 1957, 5960 nos. 40, 45 and 47; Ackermann 1975, 70-71 and 73-74 and 83-85 and 104 and 112-114), which was challenged by W. Lobo in the 1980s. As argued by W. Lobo, the position of the armed figure contrasts with the aggressive role played by Māra in the Nidānakathā. She also discards the Nidānakathā as a possible source for Gandhāran representations. Being composed in the fifth century c.e. it is indeed unlikely that the text provided a source of inspiration for Gandhāran artists. Furthermore, the Buddhacarita does not mention Māra at the occasion of the renunciation but at the moment of Enlightenment. In Gandhāran illustrations of the event, Māra is not depicted with a bow and arrow, but a sword.

5 According to $W$. Lobo, the figure should be identified as Indra or as one of the hunters (being Indra in disguise according to some sources) with whom Siddhārtha exchanges his robe. The episodes of the departure and the exchange of cloths would subsequently be conflated on the stone reliefs (Lobo 1983, 430-437). The identification of the figure as Indra has been accepted by K. Fischer (K. Fischer 1987, 61) and, to a certain extent by K. Tanabe (Tanabe 1993-1994, 157-185). As pointed out by the latter, the figure is not always Indra. His main argument is that the cylindrical tiara characteristic of many Gandhāran representations of Indra does not appear on any relief of the departure (Tanabe 2000, 1096). The second interpretation, which went unnoticed, poses a difficulty. The turban with horizontal bands and a chin band worn by hunters on Gandhāran reliefs (see for instance Ackermann 1975, 96-97 pl. XXXI and Faccenna 1962, II-3: 144 pls. 472-a and b) is not consistent with any of the hairstyles described above for the bow-holder.

6 The identification of the protagonist with one of the Four Great Kings, guardians of the four quarters of the universe, was proposed by K. Tanabe (Tanabe 1993-1994, 157185). One of the fashions (type 3 ) in which the figure is depicted on reliefs of the great departure is similar to that of one of the kings on Gandhāran illustrations of the offering of the four bowls by the Four Great Kings. Written accounts of the latter episode suggest that 
The reason for his unsecure identification holds to the discrepancy between representations of the Gandhāran departure scene on the one hand and the written accounts of the episode and ancient Indian iconographies on the other hand. Firstly, literary accounts do not always mention such a figure guiding the Bodhisattva. Secondly, when they do, his identity is fluctuating. Thirdly, a comparable protagonist is found in reliefs from India, but the sobriety of his garbs and the attributes he holds contrast with his Gandhāran counterpart. Neither tradition fully justifies both the persistency with which the figure appears on Gandhāran stone reliefs and the diverse fashions in which he is portrayed. The aim of this paper is not to propose yet another interpretation. As it will be pointed out, there is no reason to reject as a whole the hypotheses that the figure is Indra or VaiśravanaKubera. ${ }^{7}$ Rather, this article seeks to put the issue of identification into a different perspective and stresses the necessity to take into account the specificity of the Gandhāran multi-cultural context in which the reliefs were produced. ${ }^{8}$ In a region located at the crossroads of Central Asia and

Vaiśravana-Kubera, the king in charge of the northern quarter, played a more important role than the other three kings on both occasions. This would explain his somewhat individualized portrait and shed some light on the identity of the figure in departure scenes. K. Tanabe's convincing demonstration is amended in a second article where the author attempts to distinguish depictions of Vaiśravana and Kubera (Tanabe 2000, 10871100). The relevance of such a distinction is put into question by the fact that Vaiśravana and Kubera are two identities impossible to separate. A passage of the Digha-nikāya is illustrative in this respect: tamā Kuvero mahārājā Vessavaṇo ti pavuccati ([“But where Kuvera dwells, their lord is called Visānā, whence the king bears the name Vessavaṇa"]. Digha-nikāya, 32.7; Walshe 1995, 475). As it will be seen in the following section, the Lalitavistara also refers to the king in charge of guarding the northern direction both as Kubera and Vaiśravaṇa.

7 No attempt, however, will be made to reintroduce Foucher's theory that the figure is Māra as the arguments raised by both $\mathrm{W}$. Lobo and $\mathrm{K}$. Tanabe make a convincing case against it.

8 Although the chronology of the Gandhāran School remains a matter of debate, it is safe to say that the heyday of the production of Buddhist reliefs corresponds to the rule of Kushan 
which, between the fifth century b.c.e. and the fourth century c.e., was successively invaded and ruled by Iranians, Greeks, Indians and nomads from Central Asia, the diversity of religious and cultural practices and the eclectic visual landscape resulting from the broad scope of interactions are likely to have played a role in the formation of Buddhist iconographies of the region. While not denying that written or oral accounts of biographical events, as well as pre-existing iconographic traditions, were a significant source for the construction of Buddhist imageries, this article explores the possibility that they were not the only ones.

As a first step, both textual and visual traditions of representing the great departure are examined. The points on which these sources agree or diverge with Gandhāran illustrations of the event are highlighted and the extent to which these shed some light on the identity of the figure with a bow, are discussed. This approach is complemented by a second one which takes into consideration material from the large range of cultural horizons which came into contact in Gandhāra. It aims at ascertaining the pictorial sources and parallels for each of the portrayals of the guiding figure and at pinpointing the logics which might underlie these iconographic borrowings and resemblances. The possible implications of this alternative approach for the identification of the figure with a bow will then be evaluated.

kings who controlled Gandhāra from the first century c.e. to end of the third / beginning of the fourth century c.e. 


\section{Written and visual narrative traditions in the representation of the great departure}

This overview of written primary sources reporting the episode of the great departure takes into account documents which provide a reasonable point of comparison with Gandhāran images, that is to say texts which are earlier or contemporary to Gandhāran sculptures and which are known in either Indic languages or in Chinese translations. It goes without saying that these accounts should be consulted for their indicative value. ${ }^{9}$ Their dating and internal logics are often problematic and they can by no means substitute for now lost written or oral narrative traditions that could have been circulating at the place and time the reliefs were produced. In all, the sources discussed below should be considered as examples of diverse tendencies in narrating the event of Siddhārtha's flight from the palace. And, with regard to the treatment (or lack of treatment) of the guiding figure, accounts generally fall into three categories.

According to a first group of sources, the Bodhisattva was not accompanied by any escort. Such is the case of the vinaya of the Mahīsaasakas ${ }^{10}$ and of the Dharmaguptakas ${ }^{11}$, both preserved in their Chinese translations. While the former limits the intervention of divinities to dispersing Kaṇțaka's neighing and hence preventing the inhabitants of the palace from waking up, the latter only alludes to the Bodhisattva's renunciation and departure. ${ }^{12}$ The stark contrast between Gandhāran

9 Much of this literature has been considered by W. Lobo (Lobo 1983: 430-437) and K. Tanabe (Tanabe 1993-1994, 157-186; Tanabe 1997-1998, 213-233).

10 T. 22, 1421, p. 102a, L.10-102b; Bareau 1963-1995, 3: 21-22.

11 T. 22, 1428, p. 779c; Bareau 1963-1995, 3: 22-23.

12 In this respect, the Dharmaguptaka vinaya is closely related to the Ariyapariyesanā Sutta (Majjhima-nikāya, 26.14-15, Bhikku Ñāṇamoli and Bhikkhu Bodhi 1995, 256) and to the 
illustrations of the legend and the synthetic account of the Dharmaguptaka vinaya is worth mentioning since the corpora of Kharoșțhi inscriptions and of Gāndhārī manuscripts both attest of the strong presence of this sect in Gandhāra. ${ }^{13}$ In fact, an inscription associated to the Dharmaguptakas has been found at the Buddhist complex of Jamālgarhī (Konow 1929, 1103 pl. 22.01), which has yielded at least three reliefs of the great departure. Two of them are giving a complex rendering of the theme. On these examples, the Bodhisattva's going forth is witnessed by Vajrapāni and the nāgaradevatā (city-goddess) of Kapilavastu in addition to Chandaka, the bow-bearer and a cortege of devas (Cunningham 1875, 197-202 nos. C5A and C4H; Zwalf 1996, no. 176; Klimburg-Salter 1995, 182 and 275 no. 160; Errington 1987, fig. 224. The last relief is fragmentary.)

The Mahāvastu contains two allusions to the Bodhisattva's escape which compare to the above vinaya accounts ${ }^{14}$ and a more lengthy account of the

Mahāvastu, 2.17 (see note 14) which only report that going against the will of his parents, Siddhārtha went into the homeless state.

13 That being said, Chinese texts cannot always be accepted as straightforward translations of originals in Indic languages. The preliminary analysis of Gāndhārī texts belonging to the vinaya of the Dharmaguptakas conducted by M. Allon $(2008,167)$ reveals that “[...] some portions of these texts do not match their counterparts in the Chinese Dïrghãgama or Dharmaguptaka Vinaya, which is probably to be interpreted as further evidence that slightly different versions of stories were transmitted by the same school". The event of the great departure has not been preserved in the Gāndhārī corpus yet it is to be doubted that a more lengthy account of the story would have existed.

14 While staying at Śrāvastī, the Buddha briefly tells his disciples how he renounced his sumptuous home and universal kingship and withdrew towards the city of Veśâli (Mahāvastu 2.117; Jones 2006, 2: 114). Later in the Mahāvastu, Śuddhodana, his aunt and Yaśodharā each have a dream, the true significance of which (i. e. the renunciation of Siddhārtha Gautama) is respectively revealed to them by the four "Guardians of the World" (lokapāla), "the lord of the devas" (devarāja, i. e. Indra) and Brahma (Mahāvastu 2.133-135; Jones 2006, 2: 129-131). The juxtaposition of several distinct versions of the same biographical event which are likely to have been composed at different time periods is characteristic of the heterogeneous nature of the Mahāvastu. 
event which is here considered (Mahāvastu 2.140-166 [esp. 160-166]; Jones 2006, 2: 134-161 [esp. 156-161]). It illustrates a second trend according to which many divinities participate more or less actively in the event. The text indicates that thousands of devas gathered with arms full of garlands to honor the Bodhisattva, that others caused all sorts of treasures to rain down, that apsaras (celestial dancers) and gandharvas (celestial musicians) danced and sung while the Four Great Lords are complicit of the escape as they "took hold of Kanthaka's hooves." ${ }^{15}$ Shaken by the Bodhisattva's renunciation, the abode of Māra became "exceedingly gloomy" and the wicked one, "unhappy and discomfited."16 The account further reports that armies of nāga (serpents) and suparṇa (mythical birds) lords and kings "escorted the Bodhisattva" 17 and that the latter was "welcomed by thousands of devas and by the Four Great Kings" 18 as he set forth towards Anomiya. The verb puras-kri which means "to place before or in front, to cause to precede" (Monier-Williams 1960, 634. Other meanings given by M. Monier-Williams are "to make one's leader, to attend to, to respect, to honour") and which is translated by J. J. Jones as "escorted" tallies nicely with the posture of the figure with a bow on Gandhāran reliefs. However, in this case, it refers to a mythological bestiary which does not appear on reliefs.

The third group of texts is more comparable to Gandhāran images. In addition to mentioning the divinities attending the Bodhisattva in his

15 caturhi mahārājehi kaṇțhakasya pādā gṛītā // (Mahāvastu 2.160-163; Jones 2006, 2: 156).

16 atīva mārabhavanāni dhyāmāni abhūnsuhldurvarṇā nișprabhāṇi dhvajāgrāṇi mārakāyikānāṃ devānām māro ca pāpīmāṃ duḥkhī durmano vipratisārī dhyāmantavarṇo antośalyaparidāghajāto // (Mahāvastu 2.163; Jones 2006, 2: 158).

17 [...] bodhisatvam eva puraskarensuh // (Mahāvastu 2.164, Jones 2006, 2: 159).

18 bodhisatvo devasahasrehi caturhi ca mahārājehi sampratigṇ̂ito kapilavastuto dakṣinena dvādaśa yojanāni nīto mallavișayam anomiyam nāma adhișthānam vaśișțhasya ṛ̦isya āśramapadasya nātidūre // (Mahāvastu 2.164; Jones 2006, 2: 159-160). 
renunciation of the mundane life or merely witnessing the escape, they specify that one or several gods were leading and showing the way. The identity of these benevolent deities nevertheless varies. In the Sanskrit version of the Lalitavistara, the role is successively attributed to Vaiśravana, Indra (Śakra in the text) and Brahma. While making the necessary plans for the Bodhisattva's escape, the former first orders yakșas to bear the horse while he "shall march in front."19 In turn Indra declares that "he shall throw open the doors and point out the way." 20 Later in the account, no sooner has the Bodhisattva summoned Chandaka to fetch his horse than each of the Four Guardians of the Universe ${ }^{21}$ and Indra arrive at Kapilavastu and, having successively circumambulated the city, stand "saluting the Bodhisattva."22 The verse portion of the Lalitavistara tells a slightly different story according to which both Indra and Brahma (not Vaiśravana) stood in front of him and

19 aham ca purato yāsye yūyam ca vahathā hayam [...]. (Lalitavistara 15; Vaidya 1958, 147; Mitra 1998, 249). De Foucaux $(1988,178)$ translates: “Pour moi, j'irai en avant, et vous, portez le cheval."

20 svayam ca śakro devānāmindra evamāha-aham dvārāṇi vivarișyāmi/mārgam ca saṃdarśayāmi // (Lalitavistara 15; Vaidya 1958, 147; Mitra 1998, 250). De Foucaux (1988, 179) translates: “J'ouvrirai les portes et je montrerai la route."

21 In this particular instance, the king of the northern direction is not referred to as Vaiśravana but as Kubera.

22 bodhisattvam namasyamānaṃ sthitam [...]. (Lalitavistara 15; Vadya 1958, 157; Mitra 1998, 262). De Foucaux $(1988,192)$ translates: “s'y arrêta, adorant le Bodhisattva." Being composed in hybrid Sanskrit (as opposed to the classical Sanskrit of the prose section), the gāthās belong to an earlier strata of the Lalitavistara. The Chinese translation, attributed to Dharmarakșa and dated 308 c.e., predates the Sanskrit text which has come down to us. The discrepancies between both versions, the Mahāyāna character of the Sanskrit text, as well as the variety of Sanskrit used, suggest that the Sanskrit account was revised at a later date than the Chinese version and probably several times. On the problematic dating of the composition of the Lalitavistara and of its various revisions see Winternitz 1913, 242 and de Jong 1954, 313. 
indicated the best way. ${ }^{23}$ In the Pǔyào jing (普曜經) a Chinese translations of the Lalitavistara, the Bodhisattva is preceded by both Indra and Vaiśravana (Píshāmén tiān, 毘沙門天). ${ }^{24}$ The Sanskrit version of the Sanghabhedavastu (the 17th section of the vinaya of the Mūlasarvāstivādin) reports that the way was pointed out by Kubera, Indra and Brahma alike. ${ }^{25}$ Indra does not seem to be mentioned in the Chinese version of the text. ${ }^{26}$ The Chinese and Sanskrit versions of the Buddhacarita slightly differ from one another in their casting of divinities. While the Sanskrit text remains imprecise in mentioning "fiery-bodied denizens of heaven," 27 the account in Chinese (Fó suŏ xíng zàn jīng, 佛所行讚經) is somewhat more specific and refers to "nāgas and the company of Devas." Both versions nevertheless agree on that these beings illuminated the way with their innate light. ${ }^{28}$ As for the Fó běnxíng jí jing 佛本行集經 ${ }^{2}$, the source reports that Vaiśravana and “other

23 śakro brahma ubhau ca tasya purato darśyanti mārgo hyayam // (Lalitavistara 15.80; Vadya 1958: 160). De Foucaux $(1988,194)$ translates: “Çakra et Brahmâ, tous les deux devant lui, montrent la meilleure route."

24 T. 3， no. 186，506c-507b: 北方毘沙門天王與無數億百千閱叉, 手執焰光明珠威耀晃晃, 身被甲查, 從北 方來, 住北方界, 稽首菩薩。天帝釋梵與無數億百千諸天, 手執華香雜香[打可鳥]香華蓋幢幡, 來住虛空, 稽 首菩薩。

25 mārgaṃ svayaṃ darśayate kuberaḥ śakras tathā brahmasahīya eva // (Sañghabhedavastu; Gnoli 1977-1978, 89).

26 T. 24, no. 1450, 117a: 多聞及梵釋 先引菩薩路.

27 hutavahavapușo divaukaso'nye [...]. (Buddhacarita 5.85; Olivelle 2009, 158-159).

28 akrșata tuhine pathi prakāśaṃ ghanavivarapraș̣tā ivendupādāh [...]. Translated by P. Olivelle (Buddhacarita 5.85; Olivelle 2009, 158-159) as: “shined a light on his frosty path, like moonbeams coming down through an opening in a cloud." The Chinese account ( $T$. 4, no. 192, 10c) reads: 各以自力光, 引導助其明。 and was translated by S. Beal $(1883,58)$ as: "each with his own inherent light led on the way shedding forth their brightness." The same passage is translated by C. Willemen $(2009,38)$ as follows: "Each guided him with the light of his power, assisting him with their brightness."

29 T. 3, no. 190. The Fó běnxíng jí jīng (Sutra of the Collected Stories of the Buddha's Deeds in Past Lives) is presented by S. Beal as a Chinese version the Sanskrit Abhinișkramaṇasūtra done by the North-Indian monk Djñanakuta at the end of the sixth century c.e. (587). The 
gods" showed the way (T. 3, no. 190，897a: 毘沙門等示道路) and that the śuddhadevas and the devas of the kāmadhātu "went on before the Prince, leading the way." On each side, the śuddhadevas (and seemingly them only) "scattered the glorious light of their person" (T. 3, no. 190, Beal 1875, 139). Brahma, the Trāyastrimśna devas and the Four Heavenly Kings are further listed in the cortege of gods accompanying Siddhārtha in his flight (T. 3, no. 190, Beal 1875, 139).

Extent written accounts of the episode discussed alternatively describe the Bodhisattva setting off for the religious life alone or escorted by divinities of shifting identities, some of whom were guiding him. Given these inconsistencies, it is not surprising that the art historians who turn to written texts in hope of identifying firmly and unarguably the figures carved on Buddhist reliefs have had some difficulties with accounting for the presence of the protagonist and agree on his identity. Nevertheless, certain features of Gandhāran illustrations and of written accounts mutually echo each other. More weight is subsequently given to the interpretations previously suggested that the bow-holder is Indra or Vaiśravana-Kubera. For instance, on two reliefs from Loriyān Tāngai (fig. 1) ${ }^{30}$, the presence of Brahma, who is undoubtedly recognizable by his ascetic bun and Brahmanic cord, generally incites to identify the figure in front of him with Indra. ${ }^{31}$ The two gods are frequently associated on Gandhāran reliefs. This interpretation is supported by written traditions such as the Fó běnxíng jí jing, the Sanghabhedavastu and the Lalitavistara according to which both

title "Abhinișkramanasūtra", which is in fact that of the chapter dedicated to Siddhārtha's renunciation (for instance in the Lalitavistara and the Buddhacarita), is not attested for any collection on the biography of the Buddha in an Indic language.

30 See also the panel on the stūpa in the India Museum of Calcutta (Burgess 1900, 88 fig. 35; Kurita 2003, 1: no. 24).

31 The absence of a halo behind Indra's head on one of the reliefs (fig. 1), however, is surprising since Brahma is depicted with one. 
either facilitate or simply witness Siddhārtha's escape. In turn, the bow and arrow held by the figure and the heavy armor he sometimes wears on stone reliefs could be explained in light of a passage of the Lalitavistara. The text (this is the section on which K. Tanabe's hypothesis relies) reports that the yakșas sent by Vaiśravaña-Kubera as Siddhārtha is on the verge of leaving Kapilavastu are armed with all sorts of weapons including "bows and arrows" and are "protected by stout armour and mail-coats." 32 In this context, another passage from the Lalitavistara can be referred to, although not directly related to the flight from the palace. It indicates that - having taken the decision to leave - the Bodhisattva greets the four guardians of regions attended by Rakșhas, Gandharvas, and Nāgas "all attired in armour and mail-coats, armed with swords, bows, arrows and crests of jewels."33 Finally, as observed, Vaiśravana-Kubera or at least the four lokapalas are recurrently alluded to in other sources, here carrying the horse's hooves, there rejoicing at the Bodhisattva's vow. ${ }^{34}$ These brief

32 uttarasyā diśaḥ kubero mahārāja āgato'bhūt sārdham anekair yakșakoținiyutaśatasahasrair jyotīrasamaṇiratnaparigrhītair dīpikāpāṇiparigrnìtaiś ca jvalitolkāpāṇiparigrhītair dha nurasiśaraśaktitomaratriśūlacakrakaṇayabhindipālādinānāpraharaṇaparigrhītair drụhasaṃnaddhavarbhitakavacitaị [...]. (Lalitavistara 15; Vadya 1958, 158; Mitra 1998, 262). The passage is translated by de Foucaux $(1988,192)$ as: "Le grand roi de l'horizon, Kouvêra, arriva avec plusieurs centaines de Yakchas, tenant à la main des diamants, des perles, des pierres précieuses, et des torches allumées; tenant des arcs, des flèches, des piques, des javelots, des lances à deux et à trois pointes, des disques, des traits, des armes de toutes sortes, et revêtus de fortes cuirasses."

33 caturaś ca lokapālān yakșarākṣasagandharvabhujagagaṇasamparivrtān saṃnaddhadrụhavarmitakavacitān asidhanuśaraśaktitomaratriśūlahastān salīlam maṇimukuțavilambitacūọān bodhisattvaṃ namasyamānān sthitān paśyati sma [...] (Lalitavistara 15; Vadya 1958, 151; Mitra 1998, 255; de Foucaux 1888, 185). The Sanskrit is ambiguous and it is difficult to tell who is described with armour and weapons. Mitra and de Foucaux each give a different translation of the passage, attributing the attire of a warrior to the Four Lokapālas and their retinue respectively.

34 See in this regard the Buddhacarita (5.85): iti vacanam idam niśamya tasya Dravinapateh parișadgaṇā nananduh pramudita [...] translated by P. Olivelle (2009, 158-159) as “Hearing 
The Figure with a Bow in Gandhāran Great Departure Scenes.

allusions certainly do not prove that the bow-bearer is Vaiśravana-Kubera but at least do not contradict the hypothesis. In sum, nothing prevents us from recognizing Indra on Gandhāran reliefs where Brahma appears and Vaiśravana-Kubera on others. This overview of preserved written accounts of the great departure shows that various versions of the story of Siddhārtha's departure existed and that some of them did favor Indra and Vaiśravaṇa-Kubera. ${ }^{35}$

As far as visual narrative traditions are concerned, Gandhāran images share much of their general features with the early Buddhist art of the Indian subcontinent notably from Bharhut (second century b.c.e.), Sāñcī (secondfirst century b.c.e.), Pitalkhora (second century b.c.e.), Kanaganahalli (ca. first century b.c.e.) and Amarāvatī (ca. 150 b.c.e.-250 c.e.). ${ }^{36}$ Nearly all images agree on the following core elements of the composition: a horse

these words of his, the retinue of the court of the Lord of Wealth rejoiced, and hosts of deities, their minds filled with joy, announced to him the success of his vow".

35 None of the reviewed accounts however provides ground for reintroducing Foucher's theory that the protagonist facing the fleeing Bodhisattva is Māra. The latter's distress is indeed a topic in both the Mahāvastu (Mahāvastu 2.162-163; Jones 2006, 2: 158) and the Fó běnxíng jí jīng (T. 3, no. 190; Beal 1875, 137) but neither of them report that he left his abode. In fact, the Fó běnxíng jí jīng actually indicates that the assault that he launched from his abode were neutralized by the śuddhadevas.

36 It is by choice that the art of Nāgārjuṇakoṇda is not considered here. Scholars, E. Rosen Stone among others (Rosen Stone 1994), have demonstrated the close ties existing between Gandhāran art of the Kushan period and the production which developed in the region of Andhra under the Ikșvākus (ca. 225-300 c.e.), particularly the influence of the first, in addition to Hellenistic art, on the second. If one was to assume that early Indian schools were a source of inspiration for Gandhāran art, Nāgārjunakoṇda would probably not be a relevant place to take into account. Interesting to note with respect to representations of the great departure however, is the fact that the protagonist leading the rider on several reliefs from Nāgārjunakoṇda displays a lamellar amour and a turban comparable to that worn by the Gandhāran figure. For an example of such portrayal see Longhurst 1938: pI. XXVIIIC. 
in profile, an umbrella-bearer behind or beside the horse and a figure preceding the rider. ${ }^{37}$ Overall, the complexity of compositions ranges from minimal illustrations such as seen on a drum frieze from Amarāvatī ([fig. 12] Knox 1992, no. 49) and a Gandhāran panel in the British Museum ([fig. 13] Zwalf 1996, no.178. For other examples see Ackermann 1975, 83-85, pl. XXIlb [from Gumbat]; Sengupta and Das 1991, 29 no. 283 [from Loriyān Tāńgai] and Mizuno 1978, 121 pl. 104 no. 4 [from Thareli]), to expanded compositions where additional protagonists such as fly-whisk bearers, divinities, dancers and musicians join the ranks of the escort ([figs. 14 and 15] Knox 1992, no. 11; Ingholt 1957, 168; Vitali et. al. 2008, 223 no. 158). Contrasting impressions may result from the stylistic treatment of the human figure and space. The profusion of protagonists depicted in dynamic poses on the reliefs from Sāñcī, Kanaganahalli and particularly Amarāvatī gives a lively quality to the scene. By comparison, the carefully ordered Gandhāran figures or the characters in static poses on the relief from Bharhut (fig. 17) seem to participate in an action suspended temporarily.

37 The parallels drawn here pertain to composition (i. e. the ordering of figures in space) and not to motifs themselves. In this regard, a fundamental difference related to the portrayal of Siddhārtha Gautama exists between early images from India on the one hand and from Gandhāra on the other hand. While the Bodhisattva is anthropomorphically represented in Gandhāra, his presence is evoked by symbols at Sāñcī, Bharhut, Pitalkhora, Kanaganahalli and on some panels from Amarāvatī. In reliefs of his departure, he is referred to by his princely attributes (i. e. the steed and the chattra). One may also mention that the reliefs from Bharhut and Pitalkhora show the rider passing in the opposite direction and no yakșa supporting the horse's hooves. Only the relief preserved in the Victoria and Albert Museum provides a Gandhāran parallel for this peculiar representation of the Bodhisattva's escape (Ackermann 1975, 73-74 pl. XVb). 


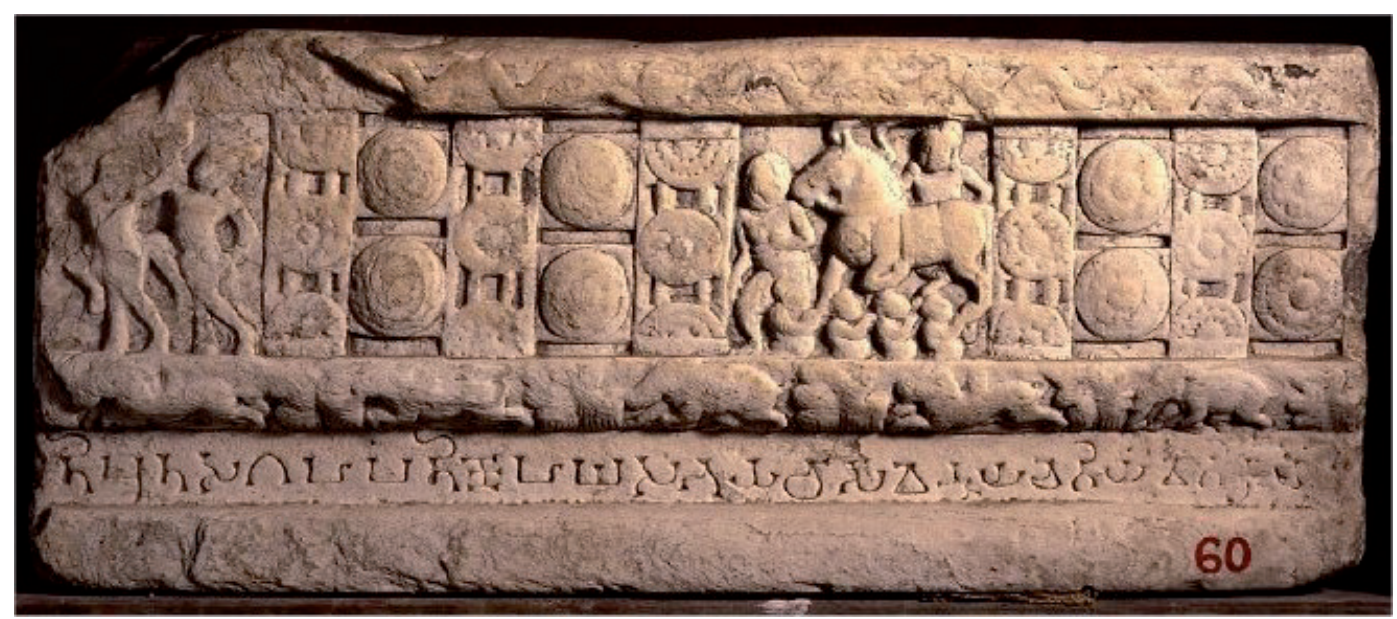

FIGURE 12 Drum frieze from Amarāvatī, British Museum, London, Acc. No. 1880,0709.60 (๔ The Trustees of the British Museum)

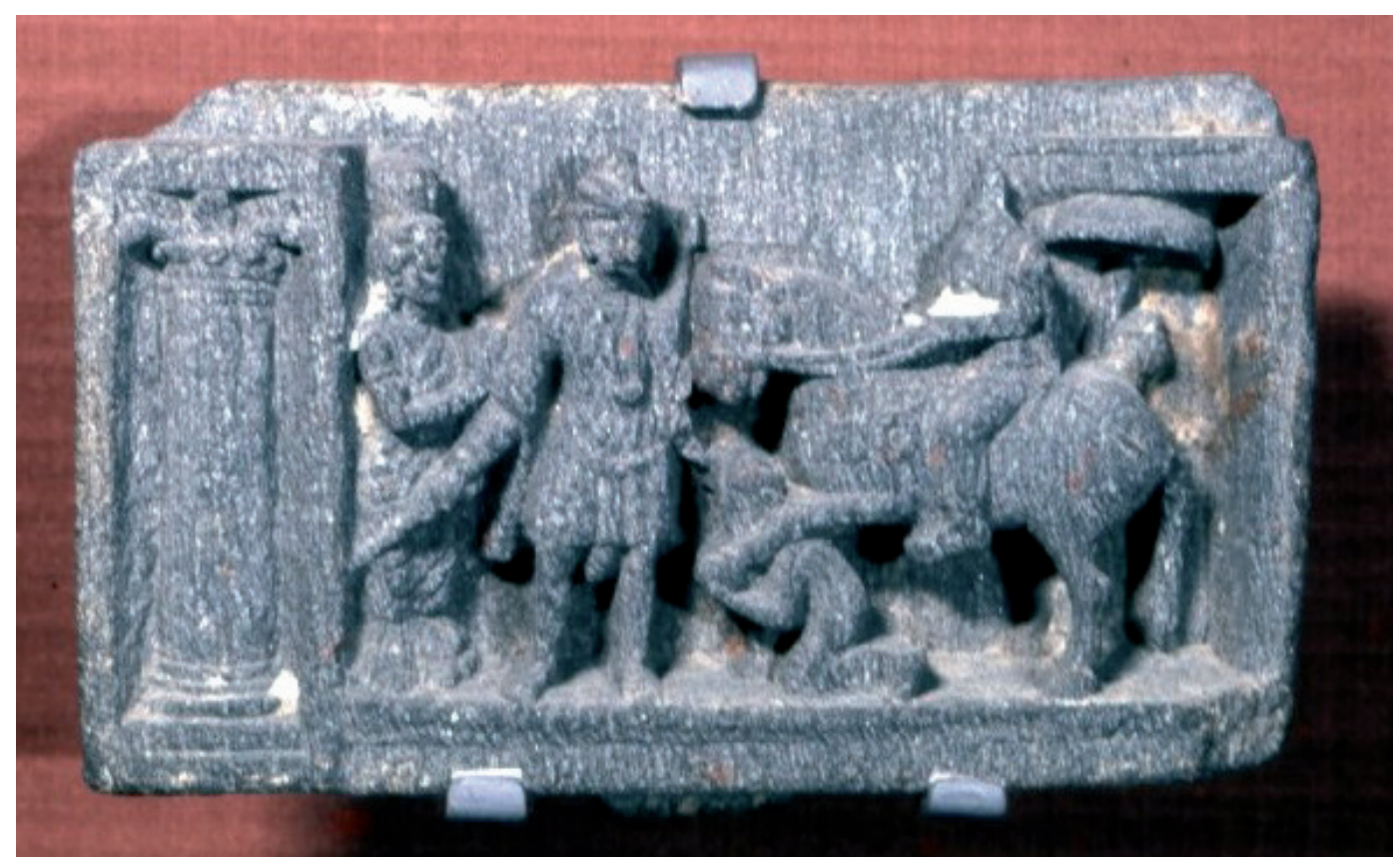

FIGURE 13 Stone relief, British Museum, London, Acc. No. 1939,0119.16 (๔ The Trustees of the British Museum) 


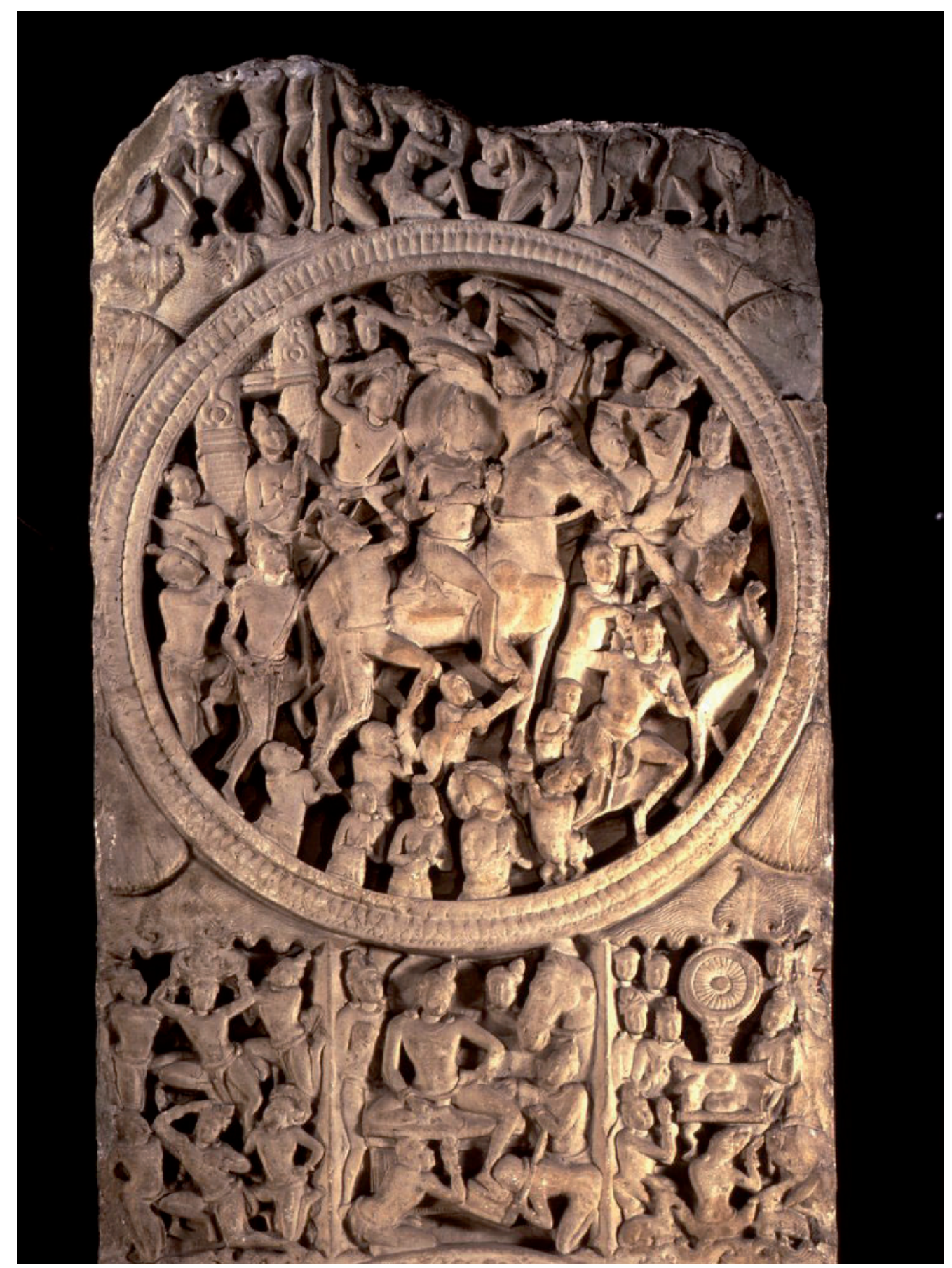

(4)

FIGURE 14 Railing pillar from Amarāvatī, British Museum, London, Acc. No. 1880,0709.7 (๔) The Trustees of the British Museum) 
The Figure with a Bow in Gandhāran Great Departure Scenes.

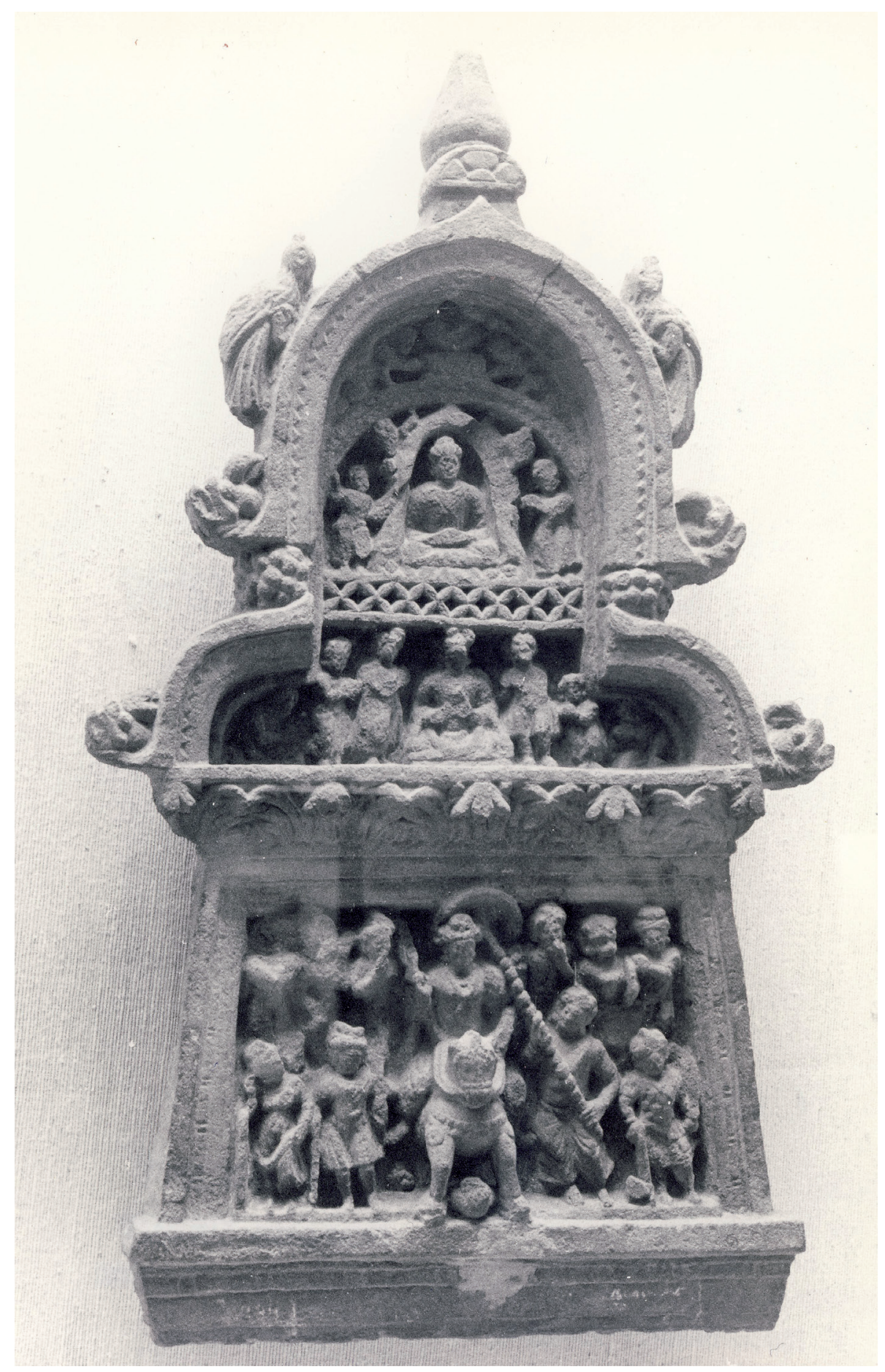

(†)

FIGURE 15 False niche, Lahore Museum, London (๔ Archives Madame Tissot, UMR 8546) 
Besides the anthropomorphic representation of Siddhārtha Gautama, Gandhāran visual tradition diverge in two respects: the appearance of a novel type of composition where by the Bodhisattva is seen a frontal position on horseback (fig. 15) and, more importantly, the treatment given to the figure preceding the Bodhisattva. Concerning the second type of composition, it shows groups of protagonists of varying sizes spread evenly on each side of the rider. In most examples, the figure with a bow is placed on the left half, while Chandaka stands on the right. The frontal depiction of Siddhārtha is likely to be a Gandhāran innovation. Gandhāran artists may well have transposed to a new subject, that of the great departure, a motif which already had a long history in both Classical and Indian visual traditions. The motif probably derives from images of Helios riding a chariot as exemplified by the coinage struck by the Greco-Bactrian ruler Plato ${ }^{38}$ as well as from depictions of Sūrya or of figures riding chariots from the Indian subcontinent. ${ }^{39}$ With regard to the leading figure, Gandhāran and Indian reliefs differ not only in the rendering of the motif, in other words the pose, the attributes and the garb but also in the meaning, or rather the identity the motif bears. Also worth noting is that while Gandhāran portrayals appear if not codified at least consistent throughout the large corpus of reliefs, the handful of examples from each of the sites on the Indian subcontinent reflect diverse tendencies. An account of these is outlined in the following paragraphs.

38 Bopearachchi 1991, 74 and 220 no. 1, pl.24, no.1. For a good reproduction see Bopearachchi et. al. 2003, 108 no. 87b. For some of these parallels see Tanabe 1997-1998, 221.

39 See for instance at Bodh Gāya, Barua 1931-1934, fig. 42. With regard to Gandhāra, a good example can be seen on the fragment from Butkara I, Faccenna 1962, II-3: 131 pl. 419b. On these two different compositions see Foucher 1905-1951, 1: 354 sqq. 
A first tendency, which gives the lead to Chandaka, Siddhārtha's groom, is exemplified by a relief from Kanaganahalli ${ }^{40}$ and two reliefs from Sāñcī. ${ }^{41}$ The panel from Kanaganahalli shows Chandaka ahead of Kaṇțhaka whose hooves are supported by four yakșas. He is followed by a small procession composed of three men wearing turbans. The latter, possibly a representation of the company of devas who facilitated the escape, are respectively portrayed astride a long stick and holding a fly-whisk and an umbrella. The identity of the Bodhisattva's servant is revealed by the lower register of the panel. It depicts Chandaka returning to Kapilavastu with Kanțhaka and presenting the prince's attire to Śuddhodana and Yaśodharā. The fashion in which Chandaka is shown is identical on all three scenes: a short paridhāna, a long sleeved upper-garment and a hooded cap.

It is also by analogy that $A$. Foucher and J. Marshall recognize Chandaka under the guise of the ewer-bearer on the reliefs from Sāñcī. On the pillar of the northern gateway representing the "four drives," (Foucher and Marshall 1983, 2: pl. 35a) also referred to as the "four encounters," Siddhārtha's groom precedes the princely chariot and is credited with a ewer. He is again depicted with the same attribute on both southern and eastern gateways. While the former gives a simplified illustration ${ }^{42}$ of the great departure

40 The full report of the excavation of Kanaganahalli has recently been published by K. P. Poonacha (Poonacha 2013). For a good reproduction of the relief from Kanaganahalli see: http://www.luczanits.net/gallery3/index.php/docu/Kanganhalli/37-South-west-side/ Kaganhalli-CL00-37-35 and http://www.luczanits.net/gallery3/index.php/docu/Kanganhalli/ 37-South-west-side/Kaganhalli-CL00-37-05 (Consulted 22/08/2014).

41 Foucher and Marshall 1983, 1: 203-204 and 2: pl. 16a (projecting end of the top lintel, southern torana) and 40 (middle lintel, eastern torana).

42 Parallels for this synthetic representation of the event can be drawn with other reliefs such as the drum frieze previously mentioned (fig. 12, Knox 1992, no. 49) and a sculpted plinth now in the Chennai Government Museum (Shimada 2012, 18-19), both from Amarāvatī and attributed by Shimada to the early phase of activity on the site (ca. 150100 b.c.e.). 
and shows only two additional figures joining hands (añjalimudrā) in the background, the latter probably offers the most complex composition. It is however confusing with respect to the portrayal of Chandaka. The nocturnal procession is repeated five times: once passing the gates of Kapilavastu, twice on the way to the forest, once in the forest and once returning. On the two first scenes, Chandaka is accompanied by a sandalbearer. Both seem to reappear on the following scene yet with a different garb: the waist garment is not represented and they are now bejeweled. Having taken leave from his Master, Chandaka returns leading Kaṇțaka back to Kapilavastu. He carries Siddhārtha's royal trappings but this time, he simply wears a short paridhāna. If the ewer-bearer is indeed Chandaka following his Master at each stage of the action, as A. Foucher and J. Marshall believe, his change of fashion is somewhat enigmatic.

The relief from Pitalkhora (fig. 16) is likely to illustrate a second trend. While the man who precedes the horse has been identified as Chandaka in previous scholarship (Parimoo 1982, 75-76), his position and attributes suggest otherwise. He is dressed with a knee-length jacket with a round collar and decorative borders worn over a dhotī. This fashion distinguishes him from the paridhāna and uttarìya worn by other attendants. The latter stand rigidly at the back, either holding the umbrella or waving a scarf (as far as one can judge from the fragmentary state of the relief), while the figure we are concerned with is running ahead. His readiness and attributes, a torch and a dagger with a curved handle, are probably less appropriate for Siddhārtha's groom than they would be for one of the deities who, as sources such as the Buddhacarita and the Fó běnxíng jí jīng report, escorted him and shed light on the way for the Bodhisattva to follow. One may, very tentatively, relate the illustration from Bharhut (fig. 17), to that of Pitalkhora. Kanțhaka is surrounded by four figures, three are at its side 
and one at its head. ${ }^{43}$ The latter holds the horse's rein in his right hand and his left leg is bent and slightly raised up, as though he was about to step forward. Unfortunately the right border of the pillar is broken off and it is impossible to know what gesture he may have made with the left hand. These features nonetheless clearly set him apart from his companions who either wave a scarf or join hands in a gesture of devotion. But his garment lend little support for his identification as all four figures are similarly dressed with a paridhāna, an uttarīya and a turban worn sideways.

A dozen reliefs from Amarāvat $\bar{i}^{44}$ form a coherent ensemble characterized by the presence of two or three men in front of the rider (fig. 14). ${ }^{45}$ In some cases $^{46}$, one of them is likely to be Chandaka, holding a circular object which has been interpreted as a duplicate of Kanthaka's rein (Parimoo 1982, 7677). In other examples ${ }^{47}$, he holds a large stick or a spear and thus armed, he rather compares to the protagonist on the Pitalkhora relief. More often than not, he displays a short tunic with long sleeves worn over a dhotī and tightened at the waist by a large cloth-belt. As for the remaining figures, they are shown in dynamic poses conveying both determination and fast

43 The same three figures, along with musicians are represented on the lower register. The continuing panel having not been preserved, it is impossible to reconstruct the rest of the scene.

44 For a recent chronology of Amarāvatī sculptures see Shimada 2006, 89-141 and Shimada 2013. With respect to representations of the great departure, a complete list is given by the author (Shimada 2012, 28 Table A). The reliefs discussed in this paragraph belong to the late Amarāvatī phase as per the author's classification.

45 Three figures, two of whom holding the umbrella and the reins, also precede the steed on a second panel from Kanaganahalli. Unfortunately, the panel is too worn to be further deciphered.

46 See for instance Parimoo 1982, fig. 111.

47 The sculptures, preserved in the Madras Government Museum, are published by C. Sivaramamurti (Sivaramamurti 1942). For a good quality image see: http://huntington. wmc.ohio-state.edu/public/index.cfm?fuseaction $=$ showThisDetail $\&$ ObjectID $=30031238 \&$ detail=largeZoom (Consulted 22/08/2014). 
pace. One leg is stretched out, the other bent at the knee and their feet are hardly touching the ground. These are unmistakably devas swiftly flying through the air, a long pleat of their short dhoti floating. Their gestures leave no doubt as to their intention toward the Bodhisattva. Their head or torso is facing the latter, one arm is bent across the chest and the other raised up or fully extended while one hand is pointing forward. They are communicating to the Bodhisattva that he must follow them.

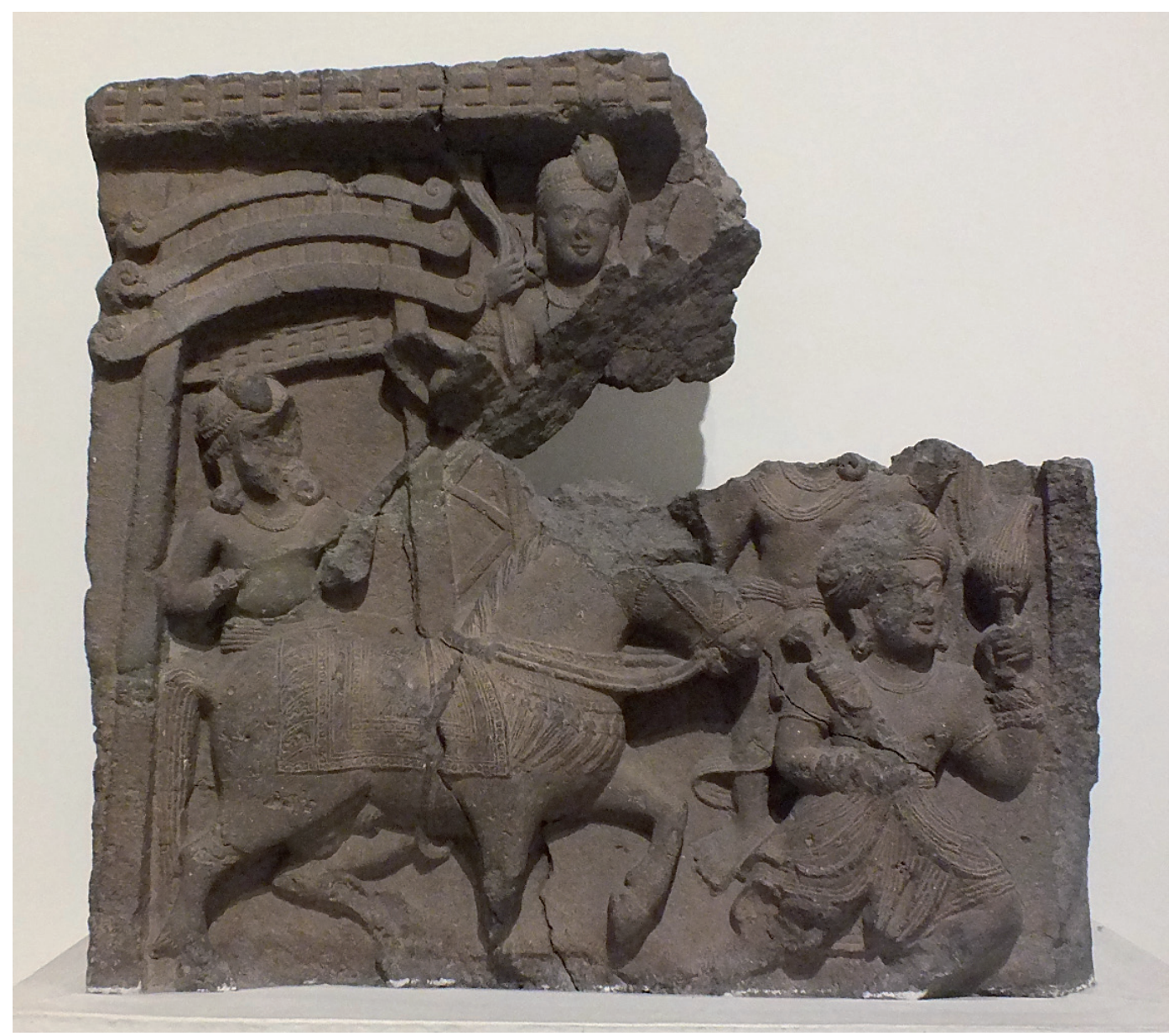

FIGURE 16 Relief from Pitalkhora, National Museum, New Delhi (Courtesy of the National Museum - New Delhi Collection; Acc. No. 67.183) 
The Figure with a Bow in Gandhāran Great Departure Scenes.

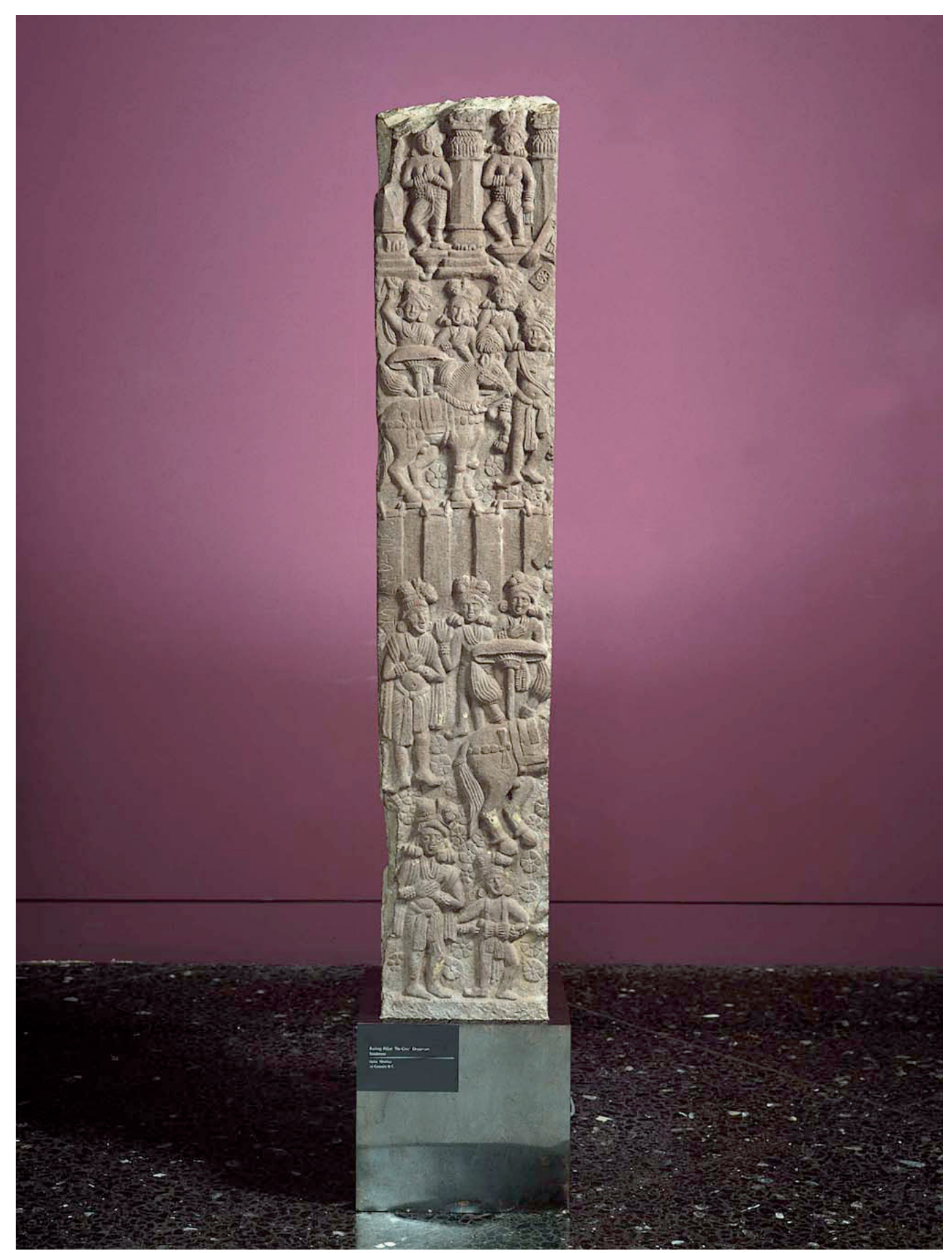

FIGURE 17 The Great Departure of Siddhārtha Gautama, Railing pillar from Bharhut,

Madhya Pradesh, c. 100 b.c. $137.2 \times 22.9 \times 27.9$ cm, Norton Simon Foundation, Pasadena (Courtesy of the Norton Simon Foundation) 
From the previous discussion, it follows that while certain visual traditions exemplified by the reliefs from Kanaganahalli and Sāñci stand in stark contrast with Gandhāran depictions, others compare to them more closely. This is the case of the relief from Pitalkhora and to a larger extent of the panels from Amarāvatī. Whereas the first shows that a guide led the Bodhisattva, the images from Amarāvatī indicate that the latter was not only guided but also accompanied by an armed escort. In sum, Gandhāran reliefs do follow a trend in the treatment of the great departure which is consistent with those reflected by some of the written and visual sources considered. Yet the extent of their resemblances is limited. Firstly, they do not fully explain the effort to produce an individualized portrayal of the guide and even less the diversity of the garbs in which he is shown. Secondly, they do not account for the choice of attributes held by the Gandhāran protagonist. Therefore, given the unusual character of the motif, it stands to reason that the mechanisms behind its formation are specific to the regional context and, as the forthcoming analysis of its pictorial sources and parallels will show, bear witness to the rich heritage of the region.

\section{Ascertaining the pictorial sources and parallels of the Gandhāran motif}

Each of the fashions previously described must now be considered in some detail. The ascertaining of their iconographic prototypes and parallels might read as a tedious catalogue but it will become evident that this is a necessary step in order to unravel some of the logics which could underlay the construction of the Gandhāran motif. 
The type with a paridhāna or dhotī, an uttarīya and a turban worn either centrally or sideways is widely used to depict both noblemen and divinities in the early art of the Indian subcontinent and of Gandhāra alike. As previously noted, this particular fashion does not constitute a criterion to identify protagonists depicted on reliefs and for lack of a distinctive attribute, it is impossible to tell the divinities apart. In consequence, their identities may only be deduced from the presence of an inscription, from the narrative context, or from the company of a conventional partner. For instance, the deity carved on a pillar from Bharhut preserved in the India

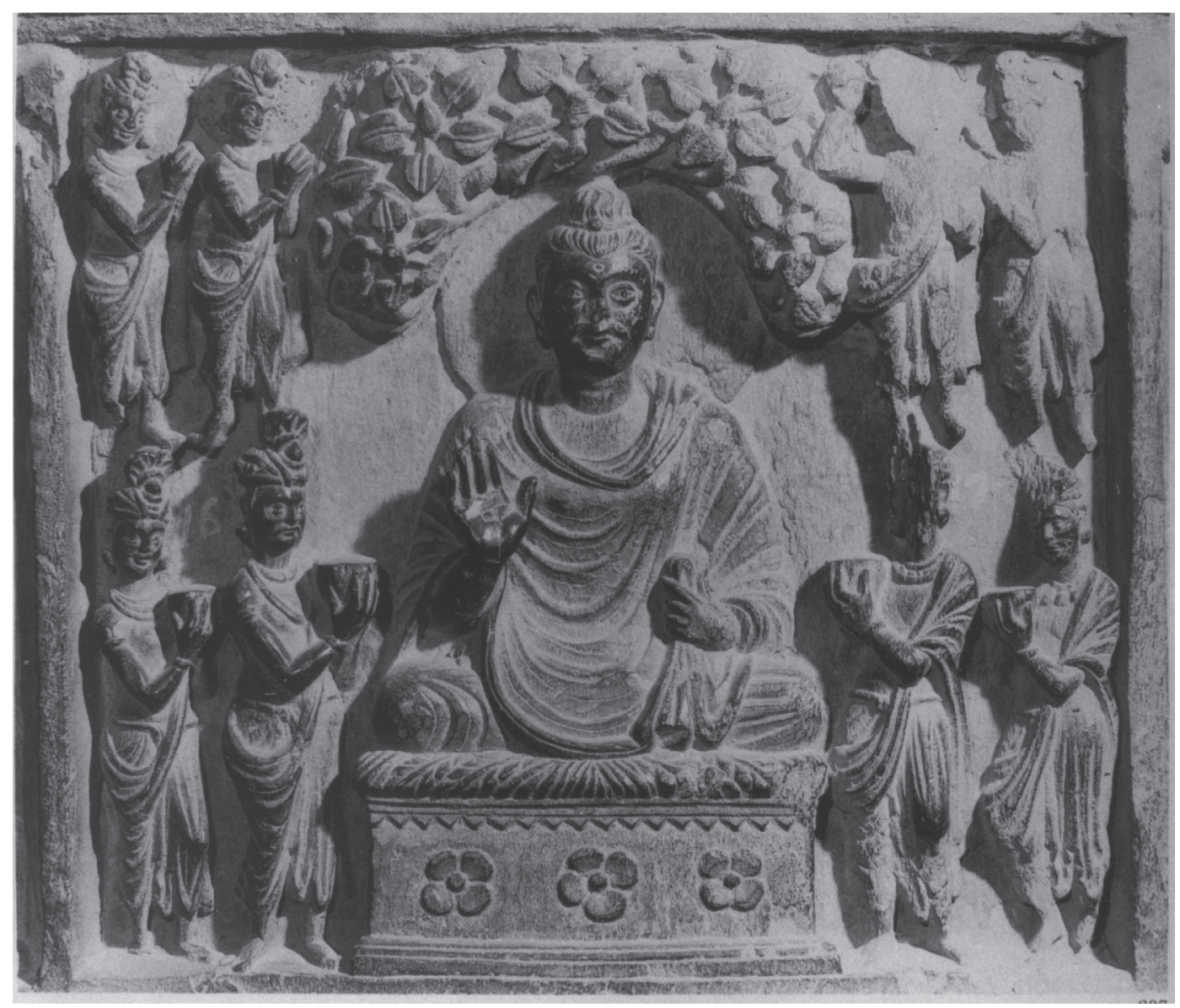

FIGURE 18 Offering of the four bowls by the Heavenly Kings, from Sikrī, Lahore Museum (๔ Archives Madame Tissot, UMR 8546) 
Museum in Calcutta is only identifiable by the inscription engraved above: "Kupiro Yaskho" (Yakșa Kubera) (Lüders 1963, 73; Bhattacharya 1987, fig. 1). The Four Great Kings are recognizable on Gandhāran reliefs because they each carry a bowl which, as the legend goes ${ }^{48}$, they have come to offer to the Buddha (fig. 18). ${ }^{49}$ The iconographic type is also used for the portrayal of Pãñcika and Indra (figs. $19^{50}$ and 20). ${ }^{51}$ The officer of the army of yakșa and the King of Gods are each recognizable because they are accompanied by Hāritī and Brahma respectively.

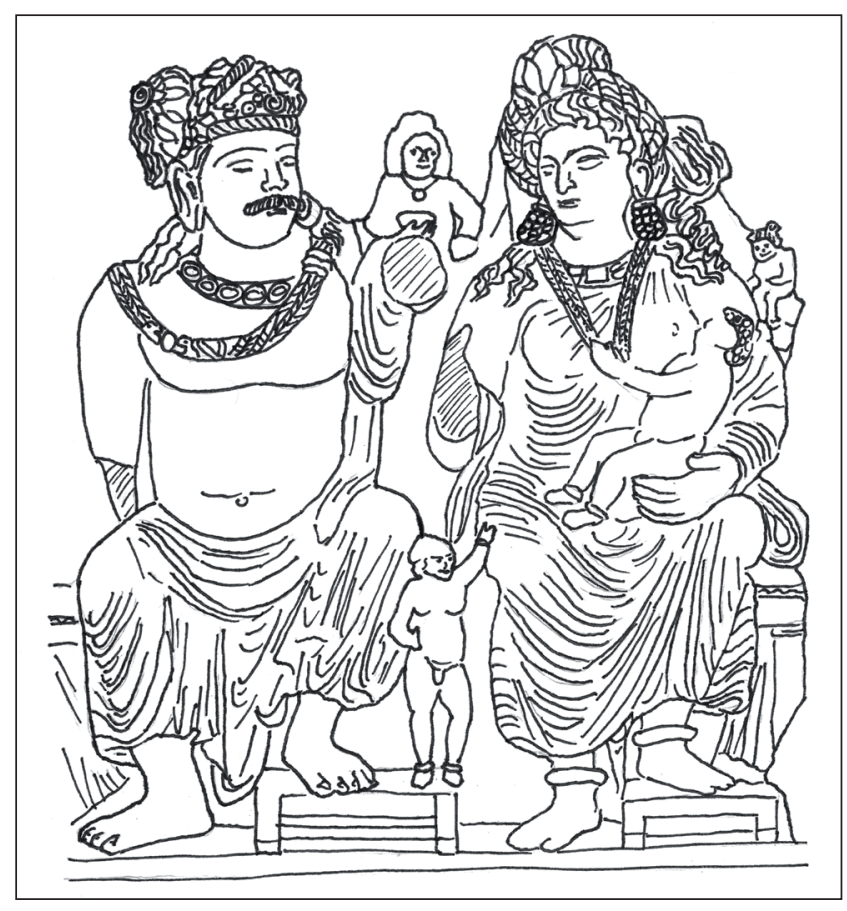

\section{FIGURE 19}

Pāñcika and Hāritī, stelae from Sahrī Bāhlol, Government Museum, Peshawar (J. Pons)

48 See for instance the account in the Mahāvastu 3.304. Jones 2007, 3: 290-298.

49 See Bhattacharyya 2002, 129 no. 546 and Ingholt 1957, no. 69 for other representations of the offering of the four bowls by the Four Heavenly Kings.

50 For other examples of representations of Pãñcika with a turban worn sideways and centrally see the sculptures from Shāh-jī-kī-Ḍherī (Ingholt 1957, no. 344) and Allahdand (Zwalf 1996, 1: 120 no. 100) respectively.

51 For other reliefs portraying Indra and Brahmā see Vitali et. al. 2008, 226 no. 165 and Kurita 2003, 1: no. 265. 


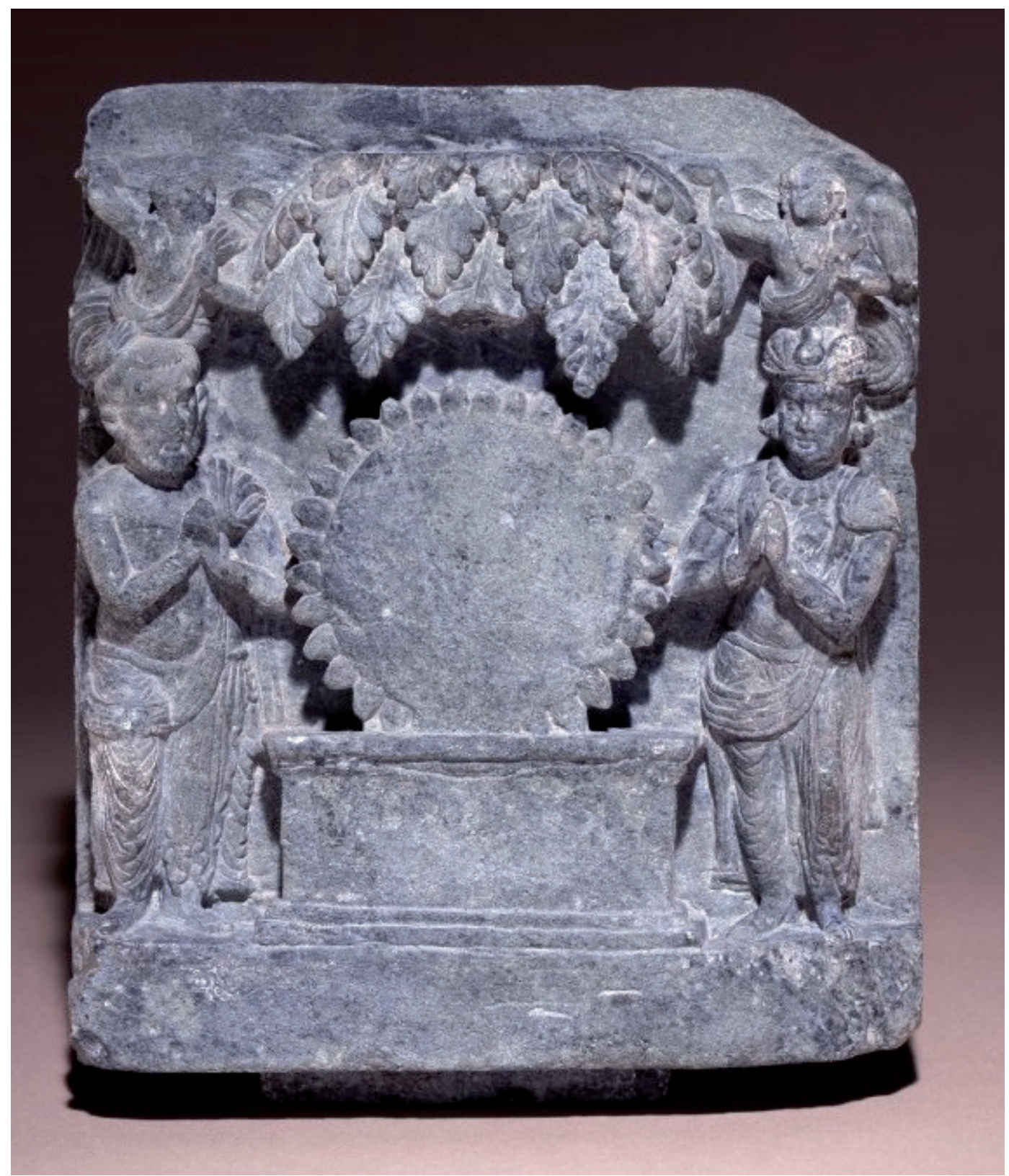

FIGURE 20 Indra and Brahmā entreating the Buddha to preach the Doctrine, British Museum, London, Acc. No. 1966,1017.2 (๔ The Trustees of the British Museum)

The type with long-sleeved tunic and baggy trousers is encountered in representations of Vaiśravana-Kubera in another narrative context ([fig. 21] 


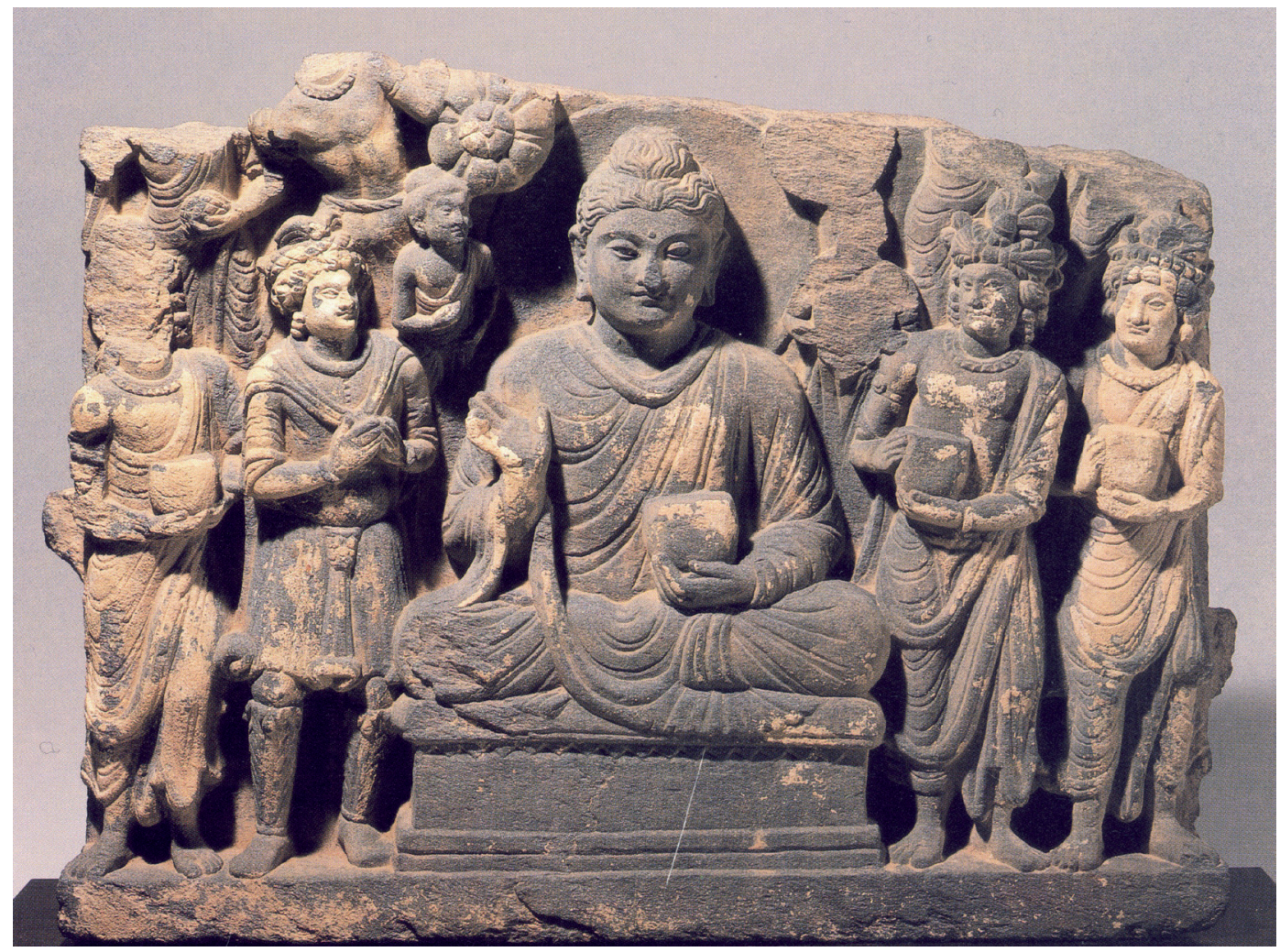

FIGURE 21 Vaiśravaña-Kubera, Offering of the four bowls by the Four Heavenly Kings, Hirayama Ikuo Silk Road Museum, Kamakurashi, Acc. No. 100120

(Courtesy of the Hirayama Ikuo Silk Road Museum)

Tanabe 1993-1994, 180 fig. 2) and derives from the art of Parthia. The stone reliefs from Palmyra, Dura Europos, Hatra or Bisutun illustrating Parthian princes may give examples of prototypes for this particular portrayal which is also common for depictions of royal figures in Gandhāra. The cross-over jacket, the large folds of the trousers and the thick dropping moustache worn by a prince banqueting on a Gandhāran stone dish (fig. 22) for instance ${ }^{52}$, are reminiscent of the statue of the Parthian ruler from the temple of Schami

52 More examples of trays carved with a similar motif can be found in Francfort 1979, 43 no. 46 pl. 23 and Tanabe 1985, 32 no. I-25. These figures also bear resemblance to the Scythian rulers Maues I and Azes I as portrayed on their coinage. Stanco 2000, 138-139. 


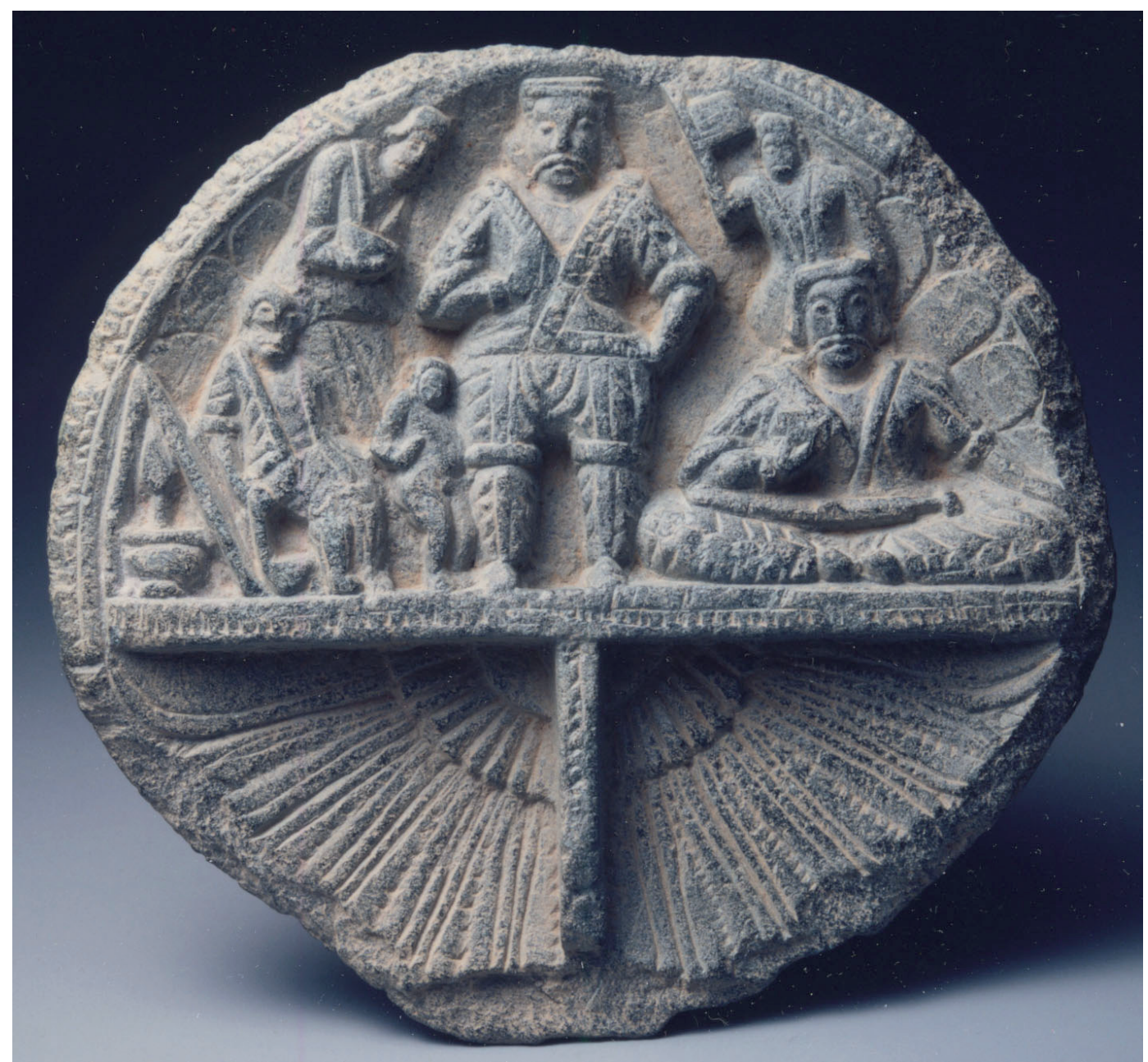

FIGURE 22 Scythian prince drinking, Gandhāran tray, Private Collection, Japan (Courtesy of I. Kurita)

in Bagdad (ca. second century b.c.e., [Ghirshman 1962, 88 fig. 99]). The felt boots, the mantle covering the tunic tied at the waist worn by Kushan rulers on their coinage ${ }^{53}$ parallel those of a Parthian prince at an altar on a relief from Bisutun (ca. first-second century c.e. [Ghirshman 1962, 53 fig. 66]).

53 Bopearachchi et. al. 2003, 181 and 199 no. 158 gives more examples of type of fashion used on the coinage of Kaniška I. 
As evidenced by representations of Pharro on the obverse of Huviška's issues (Cribb and Bracey 2011, E.C2-iii 1u), the model is also used for the portrayals of the Zoroastrian god. The winged headdress that he and Vaiśravana-Kubera are wearing, however, is borrowed from another divinity whose iconography played a significant role in shaping the next type.

As previously indicated, two variants have been observed for the type with a tunic without lower garment: the short-sleeved and long-sleeved tunic, both often worn in combination with a mantle, a winged-headdress and boots. The prototypes of the first variant are traceable to images of Hermes from the Mediterranean world. His various modes of portrayal seen on the bronze issues of the Greco-Bactrian king Diodotos I (fig. 23), of his son Diodotos II (Bopearachchi 1991, 45 and 152 pl. 2, series 12-14), and of the Indo-Scythian king Azes II ${ }^{54}$ attest of the popularity of the Greek god and of the long history of his iconography in the region. The chitoniskos (a short tunic) and the chlamys (mantle) displayed by Hermes on a relief from the Hellenistic period from Lampsaque (LIMC, 5: "Hermes", no. 349) along with his position, leaning on the front leg and lightening the way with a torch to guide the three Charites, find an echo in, for instance, representations of Vaiśravaṇa-Kubera from Bagh-Gai/Tapa-i-Kafariha (fig. 6) and Nīmogram (fig. 7). As may be observed on the coinage of Huviška (fig. 24), the pictorial model is also that of Pharro. ${ }^{55}$ The name of the Zoroastrian god is provided by the legend in Bactrian but his garment and attributes, the winged headdress and the kerykeion, are taken from his accepted Greek

54 Bopearachchi et. al. 2003, 142 and 162 no. 124. Unlike the bronze issues of the GrecoBactrian kings which only show the head of the god, the coinage of the Indo-Scythian king depicts Hermes full-length, holding the kerykeion.

55 Göbl 1984, G.346.2. While the chitoniskos, the petasos (the wide-brimmed hat) or the pilos (a rounded cap) and the kerykeion (the herald's wand) are already part of the god's attire in the Archaic period, the variety of winged headpieces appear during the Classical period. Sieber in LIMC, 5: “Hermes", 381-387. 


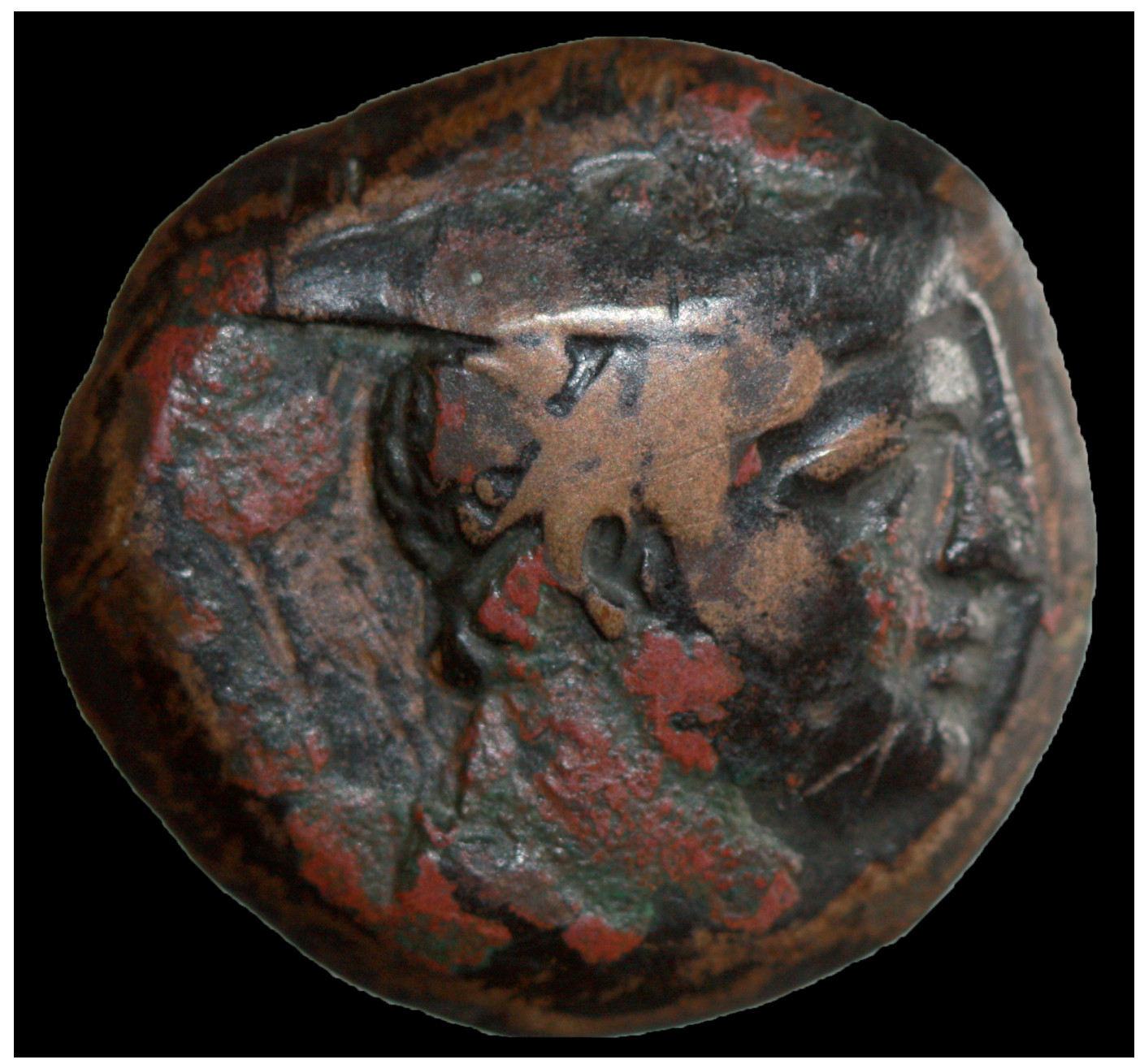

FIGURE 23 Hermes, coin issued by Diodotos I (obverse), Cabinet des Médailles, Paris (Courtesy of Osmund Bopearachchi)

equivalent ${ }^{56}$ and comparable to those carried by Hermes-Mercury on small Greco-Roman bronzes from the second century c.e. (LIMC, 5: "Hermes" nos. 974 and 975). Pharro and Vaiśravana-Kubera, however, are not the only

56 As put by F. Grenet, "the practice of seeking from Greek art what Iranian tradition was unable to provide is more systematically observed in the Kushan empire" (Grenet 2006, 88). For other examples of Zoroastrian gods depicted with the features of their Greek 


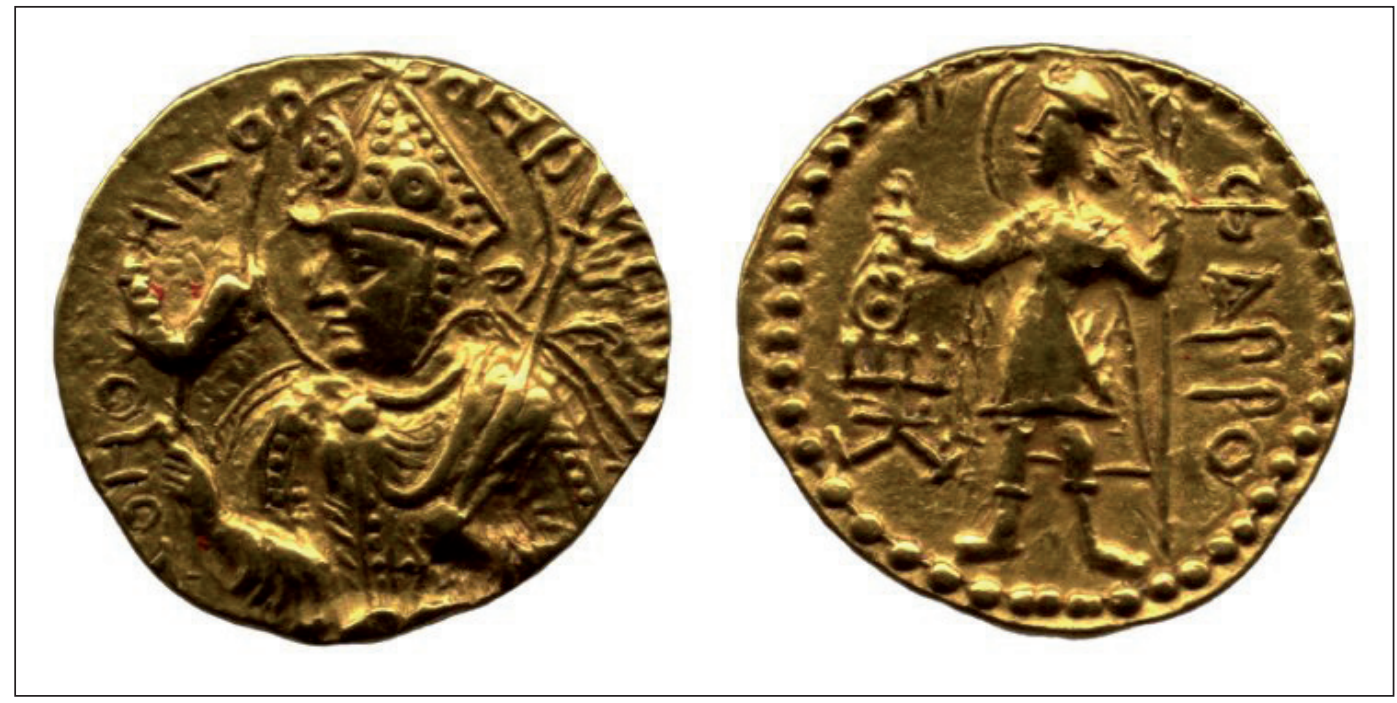

FIGURE 24 Pharro, coin issued by Huviška, British Museum, London, Acc. No. 10C.339 (๔ The Trustees of the British Museum)

divinities depicted under the guise of the Greek herald of gods. As exemplified by two images from Takht-i-Bāhī ([fig. 25] Zwalf 1996, 2: 63 no. 98; Stein 1912, fig. 2; Tanabe 1993-1994, 182 fig. 6), Pāñcika may also be shown in a similar fashion wearing either ankle-boots or sandals tied at mid-carves.

With regard to the long-sleeved tunic, it is used in other portraits of Pāñcika ([fig. 26] Spooner 1908, 12-18), Vaiśravaṇa-Kubera (fig. 27) and Pharro ([fig. 28] Göbl 1984, G.280.1). The decorated median braid (fig. 26), the wide belt or the belt with a hanging lower hem ending in a knot (Tanabe 1993-1994, 181 fig. 3), evoke the Kushan and Parthian costumes previously mentioned. Yet, none of the above gods wear the baggy trousers typical of this Iranian costume. The absence of undergarment, like the winged headdress and the boots, rather take from Classical models. This

and Indian equivalents on various supports see Grenet 2006, 87-99. The functional equivalences between Hermes and Pharro are developed in the following section. 
combination of features from disparate origins is also characteristic of the fourth and fifth types.

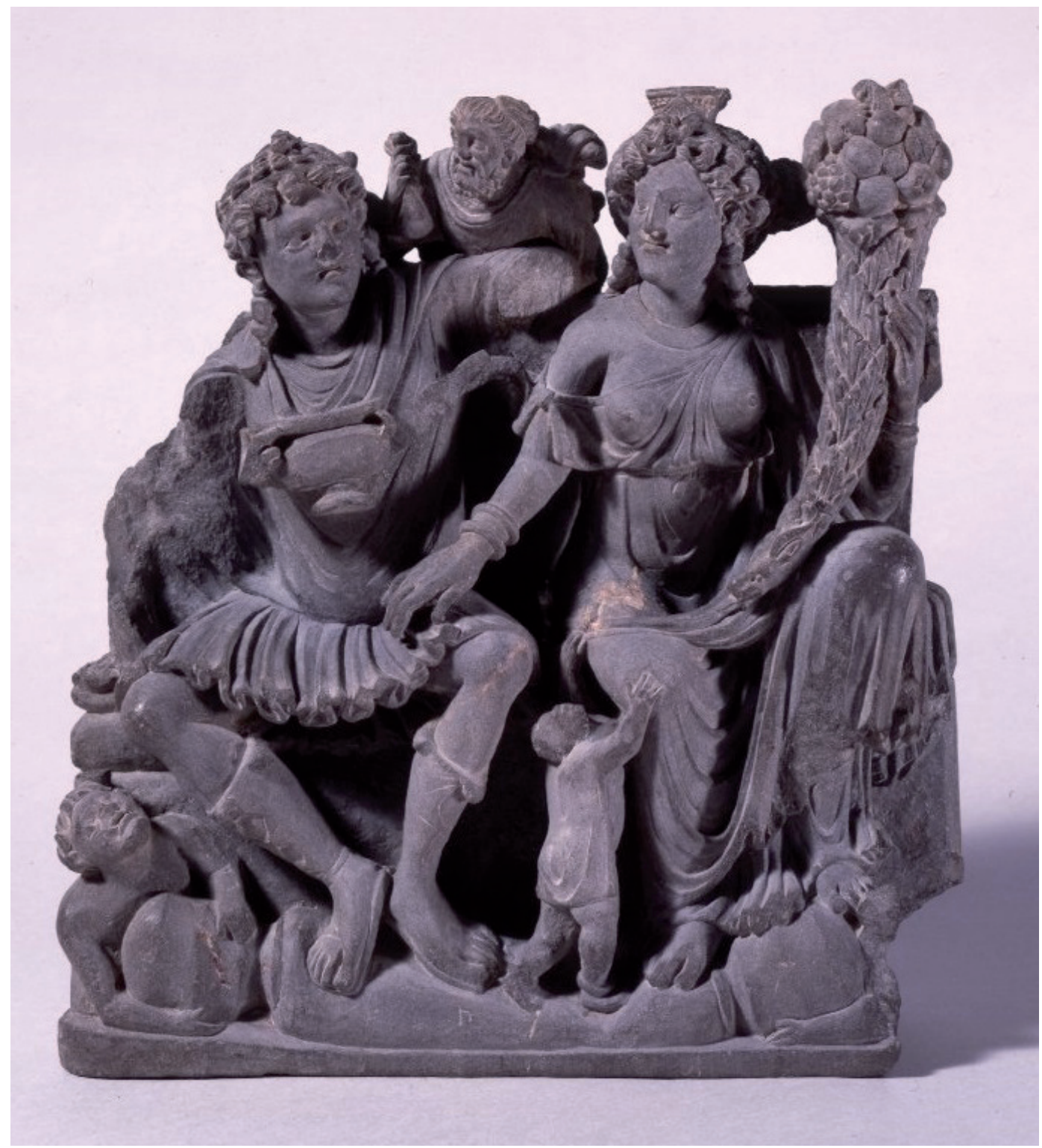

FIGURE 25 Pāñcika and Hāritī, stele from Takht-i-Bāhī, British Museum, London, Acc. No. 1950,0726.2 (๔ The Trustees of the British Museum) 

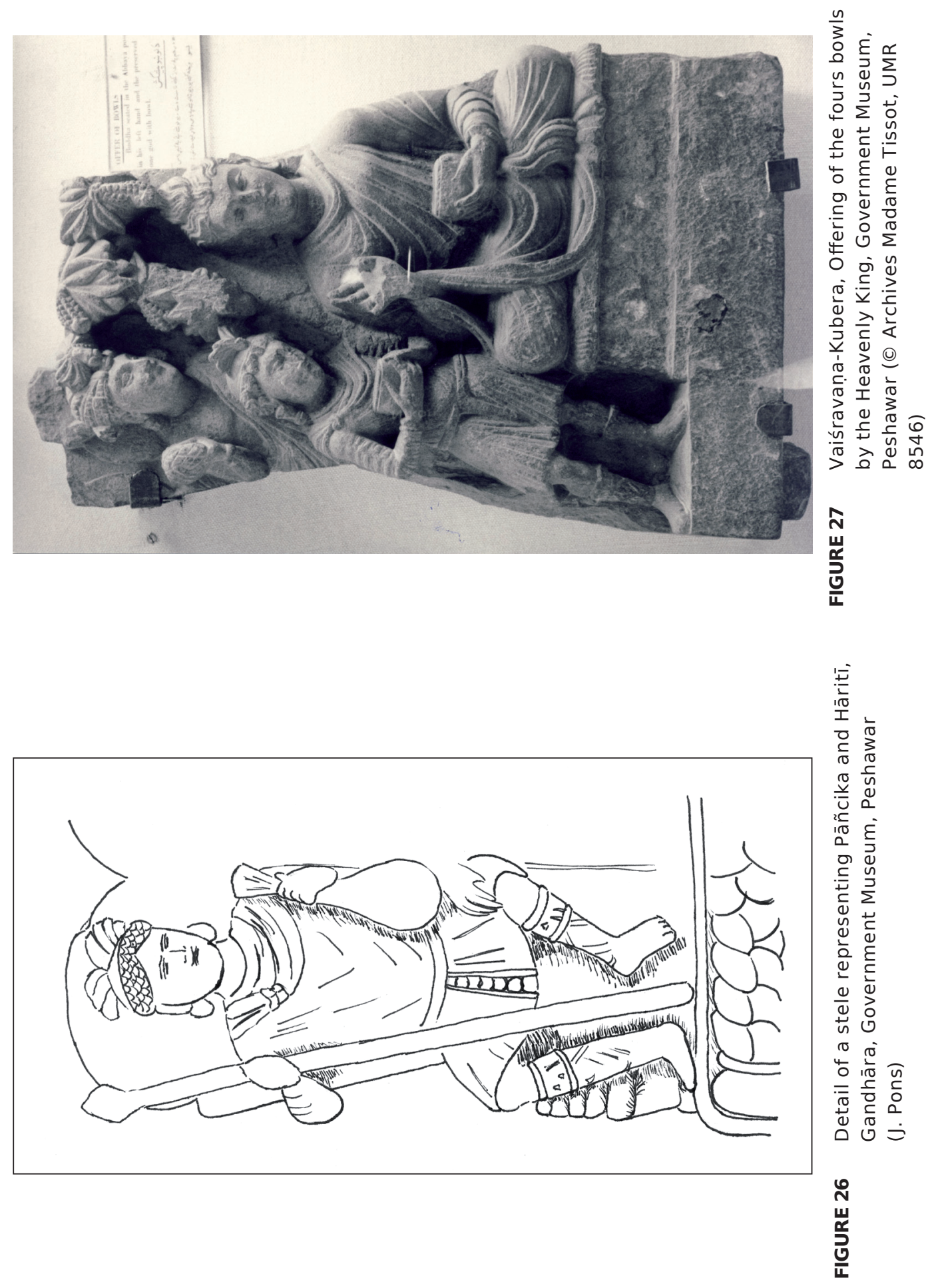


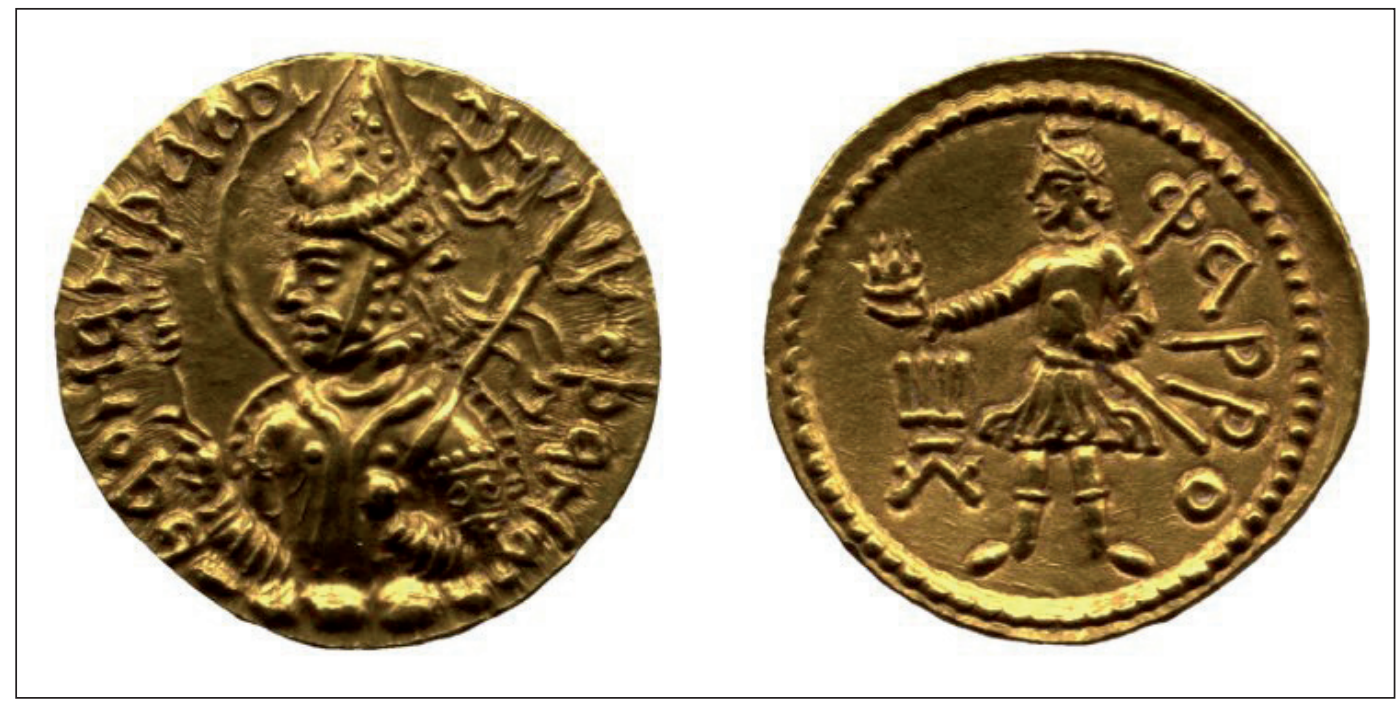

FIGURE 28 Pharro, coin issued by Huviška, British Museum, London, Acc. No. 1860,1220.204 (๔ The Trustees of the British Museum)

Dressed in lamellar armor with trousers, the Gandhāran protagonist finds equivalents in the portrait of the Kushan ruler Vāsudeva (ca. 188-230 c.e.) struck on the obverse of his golden dinar and stater issues ([fig. 29] Göbl 1984, 507; Bopearachchi et. al. 2003, 187 no. 175). The cataphractus of the military elite is itself borrowed from images of the king on a horseback struck by Scythian rulers on their coinage. These predecessors of the Kushans thus continue a fashion already attested in the second century-first century b.c.e. notably on bone plates discovered at Orlat. ${ }^{57}$ As for the winged headdress,

57 This particular fashion is referred to as "Kuṣān type" in the repertory of terms established by the IsIAO (Faccenna \& Filigenzi 2007, 172 pl. 131). However, early Kushan rulers (Vima Kadphises, Kaniška and Huviška) do not wear the lamellar armor but are clad in heavy caftans. It is only after Huviška that this fashion, retained from their Iranian predecessors, is replaced by the cataphractus. As shown by $\mathrm{O}$. Bopearachchi on the basis of the IndoGreek and Indo-Scythian coins from a hoard discovered in Bara (Pakistan), the lamellar armor worn by later Kushan rulers is borrowed from Indo-Scythians. By comparing the portrayal of Indo-Scythian rulers on their coinage with the pieces of armor discovered in the Greco-Bactrian city of Ai Khanum (ca. 146/145 b.c.e.), the frieze from the Kushan palace of Khalchayan (ca. first century b.c.e.-first century c.e.) and the bone plates found 


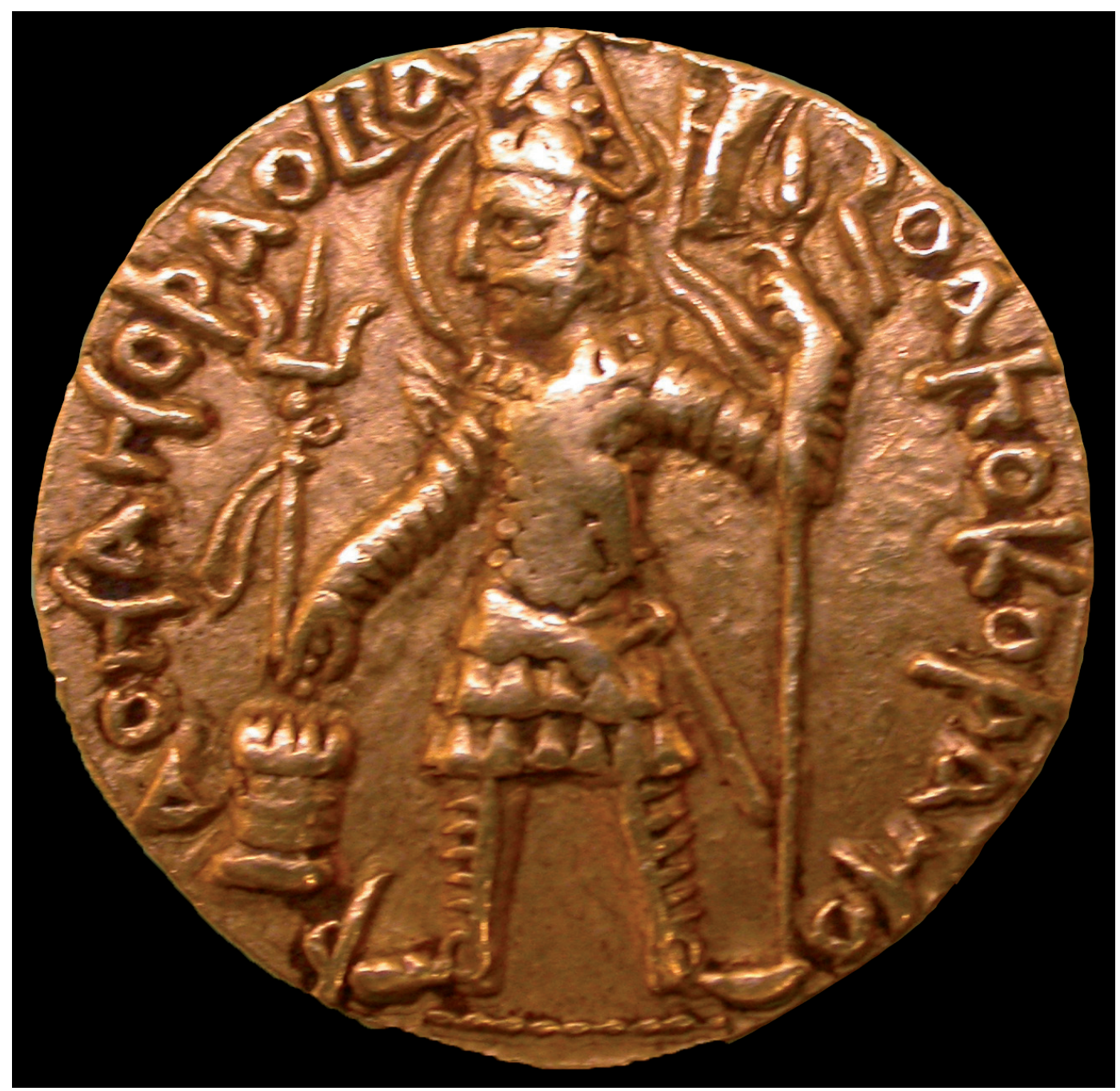

FIGURE 29 Golden stater, Vāsudeva I, Cabinet des Médailles, Paris (Courtesy of Osmund Bopearachchi)

it is again taken from representations of Hermes. In the Gandhāran context, it is found in association with the lamellar armor in depictions of Pharro on the coinage of Huviška (ca. 153-191 c.e., fig. 30. Cribb \& Bracey 2011, E.G2iib).

in the Scythian burial ground of Orlat (Uzbekistan, second century-first century b.c.e.), the author demonstrates that the cataphractus is Scythian. Bopearachchi 2003, particularly Chapter 2. 


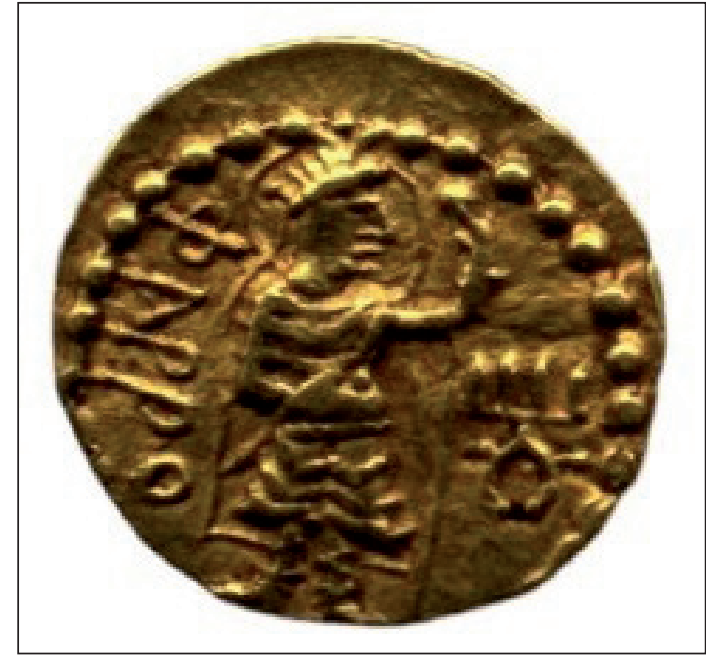

\section{FIGURE 30}

Pharro, coin issued by Huviška, Acc. No. 1894,0506.87 (๔) The Trustees of the British Museum)

Concerning variants on this type, pieces of Indian clothing (i. e. the dhoti and/or the turban) have replaced the Central Asian lower garment and the Classical headdress. As attested by the statues of Skanda-Kārttikeya from Charg Pațe (Vitali et. al. 2008, 161 no. 112) and Kāfir Koṭ ([fig. 31] Zwalf 1996, 1: 121 no. 102) ${ }^{58}$ as well as by the headless image of Pãñcika attended by Hāritī discovered in Butkara I (Faccenna 2001, pl. 90a and pls. 91a and b ), other gods display a similar combination of diverse garbs. As noted by D. Faccenna, however, the portrayal of the officer of yakșas as a warrior differs from more common representations previously considered where the latter is dressed with a short tunic. ${ }^{59}$

58 See also Swati 1997, 49 pl. 38 and Vitali et. al. 2008, 160 no. 111 for other examples. This mode of portrayal (with lamella armor and paridhāna or dhotī) is called the "Indo-Greek type" in IsIAO's repertory of terms (Faccenna \& Filigenzi 2007, 171 pl. 130). This type probably refers to the juxtaposition of the thorax and metal skirt of the Classical armor with the Indian paridhāna. However, the term "Indo-Greek" might be misleading. As it was pointed out by O. Bopearachchi, none of the Greek rulers from Gandhāra and the Punjab (Indo-Greek rulers) was depicted with this specific armor.

59 D. Faccenna who could not have been aware of the material from Bara and Orlat has compared this type with the representations of Parthian warriors from Palmyra and Dura Europos (Faccenna, 2006, 183; Seyrig 1941, 31-44). 


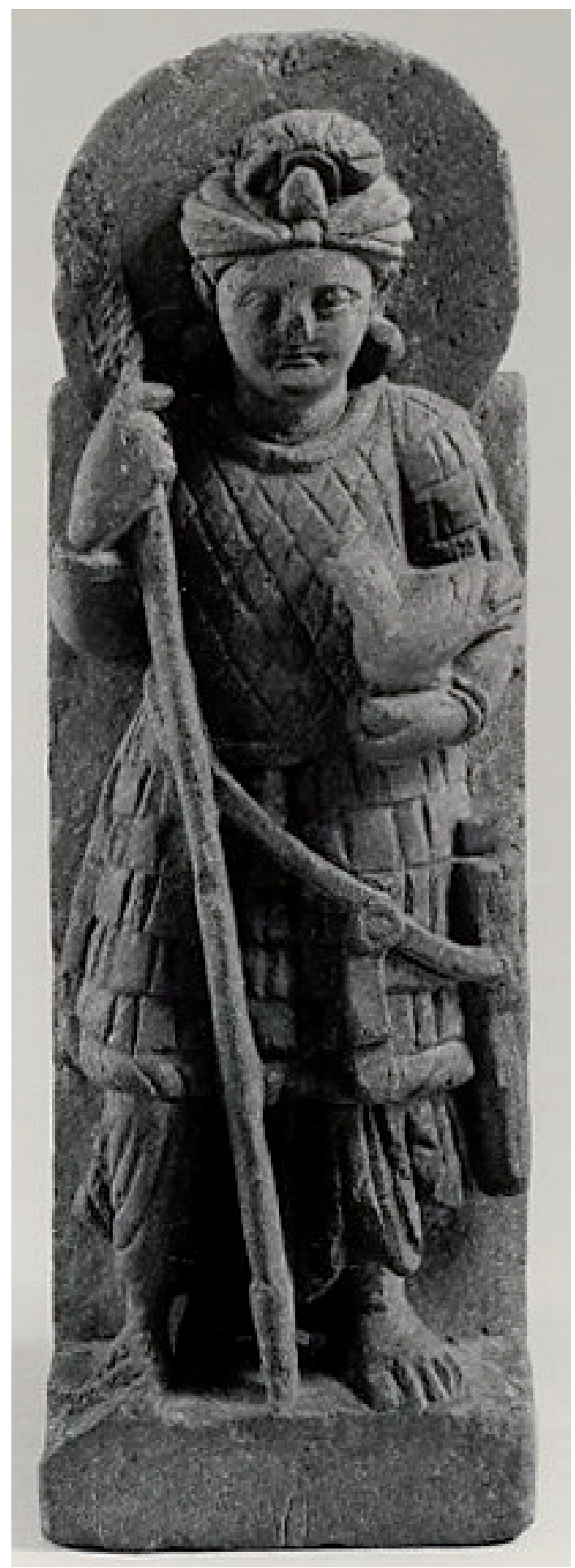

\section{FIGURE 31}

Skanda-Kārttikeya, stelae from Kāfir Koț, British Museum, London, Acc. No. 1899,0609.6 (๔ The Trustees of the British Museum) 
Similar dynamics seem to be at play in the fifth and final type showing the figure dressed in a long sleeved tunic and a dhotī. Although Indra is more frequently depicted with a paridhāna and an uttarìya, he is shown in this fashion on the relief from Loriyān Tāngai previously mentioned (fig. 11). This assemblage of the Kushan upper and the Indian lower garments nevertheless finds a parallel in a small stele preserved in the Victoria and Albert Museum (Ackermann 1975, 82-83 pl. XXIb).

Examining the pictorial sources for each of the various portrayals of the bow-bearer indicates that his iconography draws upon a variety of sources: Hellenistic, Greco-Roman, Parthian, Scythian and Indian predominantly. These modes of portrayal are characteristic of Gandhāran imagery in that they exhibit various degrees of likeness to objects found, say, in the Mediterranean West or in Central Asia. For instance, the type with chitoniskos suggests that artists were familiar with Hellenistic modes of portrayal of Hermes-Mercury. Other types, however, mix iconographic motifs from various artistic traditions. Worn without a lower garment, the long-sleeved tunic with a median braid looks like a chitoniskos which was tuned to Iranian aesthetics. As for the last two types, they display an assemblage of garments from Central Asian, Western and Indic origins. Thus, in light of the foregoing discussion, one may conclude that the construction of the portrayals of the Gandhāran motif feeds upon a rich pool of pictorial traditions which came into contact in Gandhāra and that the diversification of the modes of representation owes to the large range of pictorial models existing in the region. In other words, the rich heritage of Gandhāra has fostered the diversification of the motif.

What this examination of pictorial sources and parallels fails to account for, however, is the systematic presence of the bow, and that (less systematic) of the arrow. As noted above, the bow and arrow are solely listed in the 
Lalitavistara among the many weapons attributed to Vaiśravana-Kubera and/or his yakșas retinue on the occasion of Siddhārtha's escape. In fact it is this passage which has lead K. Tanabe to identify the bow holder as Vaiśravana-Kubera, who armed in this way, would protect the Bodhisattva. ${ }^{60}$ In a second article, $\mathrm{K}$. Tanabe reconsiders his interpretation and attaches a new meaning to the two weapons carried by the protagonist, this time associated to "light and the dispersal of darkness" (Tanabe 1997-1998, 222). His demonstration is based on a carving on a railing pillar from Bodhgaya depicting Sūrya on the quadriga. The sun-god is framed by Ușā and Pratyușā, respectively personifying dawn and crepuscule and respectively holding a bow and an arrow. The author establishes a parallel between Sūrya and the Bodhisattva on the one hand and VaiśravanaKubera and Ușā and Pratyuṣā on the other. He subsequently concludes that armed with the bow and the arrow, borrowed from Ușā and Pratyușā, Vaiśravana-Kubera disperses the darkness in front of the Bodhisattva.

The hypothesis is interesting and to some extent in line with versions of the legend reporting that deities cast light onto the path. Yet it is not entirely convincing, in part because the claim deserves to be further substantiated. It is not certain that the comparison between sculptures which were produced three centuries apart is sufficient to prove $\mathrm{K}$. Tanabe's point. Besides, several other documents weaken K. Tanabe's interpretation. Firstly, the corpus of Gandhāran sculptures counts more depictions of Sūrya on his chariot without Ușā and Pratyuṣā than with. This leads one to question the extent of the light symbolism attached to the two weapons, at least in the region. Secondly, one may contend that

60 According to $W$. Lobo, the bow and the arrow are not combat weapons but weapons used by the hunters with whom the Bodhisattva exchanges his dress (Lobo 1983, 436). The reasons why this hypothesis does not hold have been stated above (see note 5). 
the representation of a torch would be likely to constitute a visual signal more effective in conveying the function of a 'disperser of darkness.' The aforementioned relief from Pitalkhora does indicate that a torch was in fact employed. ${ }^{61}$ Therefore, given the existence of both visual and written traditions describing numerous devas in armors and holding weapons while escorting the Bodhisattva, one is more tempted to accept K. Tanabe's first interpretation that Vaiśravana-Kubera, and to this we may add possibly Indra, are guarding or protecting the Bodhisattva with the help of the bow and arrow.

In the remaining section, I would like to consider the possibility that the iconographic motifs used to portray Vaiśravana-Kubera and Indra are endowed with additional meanings or identities. To put it differently, could other divinities be recognized on Gandhāran illustrations of the great departure under the guises characterized for Vaiśravana-Kubera and Indra? As previously highlighted, material evidence shows that in Gandhāra, some of the fashions described were also common to representations of other gods associated to other religious pantheons coeval in Gandhāra, namely Pāñcika, Pharro, Skanda-Kārttikeya and Hermes. One may argue that the introduction of a Zoroastrian, Brahmanical or Classical god would be a mismatch to the Buddhist propos. However, for reasons that will now be developed, it is an assumption which is worth testing.

61 This is also the case on a relief from Pagān which the author mentions to support his hypothesis on the light symbolism attached to the bow and arrow. Tanabe 1997-1998, 222. 


\section{The protective function of Buddhist, Brahmanical, Zoroastrian and Classical gods}

Previous scholarship has pointed out the links existing between some of these divinities and underlined how iconographic borrowings or similarities may mirror functional correspondences. Each of the divinities listed are invested with several functions and associated to various concepts in their respective pantheons. In this case, Vaiśravaṇa-Kubera, Pāñcika, Indra, Skanda-Kārttikeya, Pharro and Hermes are predominantly connected to ideas of leadership, protection, fertility and ambivalence. ${ }^{62}$ Nonetheless, it must be noted that these correspondences should not be considered as a fixed system of relationships. The reason for this is that the very nature of the divinities in question can hardly be envisaged as monolithic. Qualities

62 Neither an extensive account of the shifting natures of the six divinities nor a list all scholarship dealing with the iconographic or functional associations between the Buddhist, Brahmanical, Zoroastrian and Classical gods can be given here. The following studies or introductory chapters dedicated to the various gods or to the connections between them can be noted here. The figure of Vaiśravana-Kubera has been the topic of several monographs, doctoral dissertations and articles, see for instance: Bedeker 1969, 425451; Modhey 1971-1972, 299-306; Klimburg-Salter 1981, 253-262; Tanabe 1999; WesselsMevissen 2001; Satapathy 2002; Astier 2014. An introductive discussion on Indra's status and symbolism is given in the recent translation of the Rg-vedic hymns by Jamison and Brereton 2014, 1: 38-40. The most recent and complete study on Skanda-Kārttikeya is that of Mann 2012. The works of Agrawala 1967; Chatterjee 1970; Ghurye 1977; Sinha 1979 and Srinivasan 1997-1998, 233-264 can also be mentioned. With regard to Pharro see Bailey 1971; Shabazi 1974, 135-144; Shabazi 1980, 119-147; Skjærvø 1983, 241-259 and Lubotsky 1998, 478-488. With respect to Hermes: Bruchmann 1893; Sieber 1990, 285-290 and 373387; Vergados 2013. Concerning the ties linking some of these gods or more broadly the issue of multiple identities, of particular relevance are Gnoli 1963, 29-37; Taddei 1966, 89-93; Grenet 1995-1996, 277-297 (Vaiśravaṇa-Kubera/Pharro); Grenet 2006, 8799 (Pharro/Hermes); Johne 2003, 421-438 (Pāñcika/Pharro); Quagliotti 2003, 239-293; Quagliotti 2005, 271-291; Quagliotti 2008, 126-129 (Pāñcika/Vaiśravaṇa-Kubera/Pharro); Mann 2012, Chapter 6, 123-148 (Skanda-Kārttikeya/Pharro/Orlagno/Sraošo); Astier 2014, Chapter 3 (Pāñcika/Vaiśravaṇa-Kubera/Pharro). 
of gods have been shaped and reshaped over time, in response to global or local circumstances, and are described or visually transcribed in documents whose date or place of production, composition or compilation are often problematic. It is difficult to determine which aspect(s) of a particular divinity was/were emphasized or disregarded at a given time and place and if so, whether this was the case in all parts of the population or only in some. In the following paragraphs, attention will be drawn to a salient feature of the characters of Vaiśravaṇa-Kubera, Indra, Skanda-Kārttikeya, Pāñcika, Pharro and Hermes and particularly relevant to the narrative context of the great departure: protection. Ensured either by kingly rule, military power, wit or prophylaxis, is it certainly a significant quality shared by all the divinities drawn together by the iconographic analysis.

With respect to Vaiśravana-Kubera, restricting ourselves to Buddhist sources, at least to begin with, he is unequivocally referred to as one of the four great kings of the quarters (of the universe) (Pāli: cātummahārājāno, Sanskrit: catur-mahārāja) also referred to as the four guardians of the regions (lokapālā). In this regard, he is associated to the northern quarter. The most detailed account of their defensive function, and incidentally of Vaiśravaṇa-Kubera's, is probably that of the Āțānāțiya Sutta (Dīgha-nikāya, 3.32; Walshe 1995, 471-478). After having "set up a guard, a defensive force, a watch over the four quarters," (Dïgha-nikāya, 3.32.194; Walshe 1995,471 ) the four kings proceed to meet the Buddha in order to transmit to him the Ātānāța protective verses, by means of which followers of the Buddha "may dwell guarded, protected, unharmed and at their ease" (Dīgha-nikāya, 3.32.194; Walshe 1995, 471-472). These verses, recited by Vaiśravana-Kubera himself, describe each of the four directions, the north being: 
[...] guarded by a king,

Mighty in power and fame is he,

Lord of all the yakkha folk,

And Kuvera is his name. ${ }^{63}$

A passage in the Mahāvastu is also quite telling of the four kings' power and protective charge. Here, the Buddha pronounces a blessing on Trapusa and Bhallika who ought to be watched over by the "Four Great Kings, glorious guardians of the world" who "with blazing radiance guard the four quarters." ${ }^{64}$ Again, Vaiśravana-Kubera is associated to the northern quarter and presented as "Iord and king of all the yakșas" (sarvayakșādhipo rājā). ${ }^{65}$ Although probably laying more emphasis on Vaiśravaṇa-Kubera's quality as god of wealth, similar traits are depicted in the epic literature of the Mahābhārata and the Rāmāyaṇa. ${ }^{66} \mathrm{~A}$ vivid description of VaiśravaṇaKubera's fighting yakșa and rakșasa host is given in the Mahābhārata (Mahābhārata 3.3.160), which alternatingly refers to the gods as the "lord of all yakșas," the "king of yakșas," or the "lord of treasures." As for the Rāmāyaṇa, it reports that his functions of guardian and protector of the world were boons granted by Brahma (Rāmāyaṇa, Sundarakānda, 7.11; Goldman and Sutherland Goldman 2007, vol. 5, 10).

63 yam disam abhipāleti mahārājā yas assi so yakkhānaṃ ādhipati Kuvero iti nāma so [...]. (Digha-nikāya, 3.32.203; Walshe 1995, 476).

64 catvāraś ca mahārājā lokapālā yaśasvinaḥ/prajvalamānavarṇena rakṣanti caturdiśam // (Mahāvastu 3.310; Jones 2007, 297).

65 Mahāvastu 3.309; Jones 2007, 3: 296. For a discussion of Vaiśravaṇa-Kubera's function as protector of the kingdom of Khotan see Anderl (forthcoming).

66 The Yajurveda (1.8.7), the Atharvaveda (1.3) and the Śatapatha Brāhmaña (3.6.4) also assign gods to each of the four directions. Their identities however differ from those found in the Buddhist and epic narrative contexts. The northern region is for instance attributed to Varuna or Soma. On this see Coomaraswamy 1971, 2: 31. 
Contrary to Vaiśravana-Kubera who figures in accounts of the high deeds of major gods of Buddhism and Brahmanism alike, Pāñcika, the great general of the latter's army remains essentially associated to the Buddhist sphere. In the Prātihārya-sūtra and the Sudhanakumāra-avadāna of the Divyāvadāna, the latter is explicitly presented as the Heavenly King's mahāyakșasenāpati or simply yakșenāpati ("the great field marshal of the yakșas" or "leader of the yakșa army") (Divyāvadāna 12.101 (Rotman 2008, 281-282) and 30.290 (Tatelman 2005, 260-261). In these stories, Pāñcika respectively summons heretics to take refuge in the Buddha and leads the troop of yakșas to defeat a recalcitrant hill-tribe chieftain. Pāñcika's dedication to the Buddha and his doctrine is also illustrated in the account of the great departure as given by the Lalitavistara. There, upon hearing that the Bodhisattva will renounce his princely life, the "yajñasenāpati" commands that "we [yakșas] should exert ourselves for his worship."

The wealth of hymns addressed to Indra in the Rg-Veda present him as the most prominent god whose greatest deed is to have slayed with his vajra the gigantic cobra Vrtra which blocked the course of waters. His warlike nature makes him a symbol of power and of heroism and as the destroyer of Vrtra, the paradigm of obstacles ${ }^{68}$, of protection. Indra remains portrayed as the chief of deities and praised for his military prowess in the later mythology of the Mahābhārata and the Rāmāyaṇa as well as in Buddhist legends. In the Rāmāyaṇa for instance, he appears as a standard of comparison with valiant warriors such as Rāma, to name but one:

67 tasya yuṣmābhị pūjākarmaṇe autsukyamāpattavyam // (Lalitavistara; Vaidya 1958, 146; Mitra 1998, 249). Translated by de Foucaux $(1988,180)$ as “Empressez-vous donc de lui offrir œuvre de sacrifice."

68 For a recent translation of Rg-vedic hymns Jamison and Brereton 2014, 3 vols. 
Once Bharata's older brother had slain in combat Kumbhakarna, crusher of the hosts of the gods, whose efforts had never before been thwarted in great battles, he rejoiced, as did Indra, the lord of the immortal gods, when he had slain the great asura Vrtra. ${ }^{69}$

In the Buddhist cosmological system, Indra or Sakka (Sanskrit: Śakra) is the king or chief of gods (Pāli: devānam indo, Sanskrit: deva indra) and lives in one of the worlds of devas named Tāvatimsa (Sanskrit: Trāyastriṃśa). ${ }^{70}$ Several jātakas describe him driving asuras away from the realm of devas, yet by outwitting them rather than by force. ${ }^{71}$ However, both Buddhist and epic legends often place him in a position subordinate to other gods. His active figurations in major events of the Buddha's previous and last existences are probably illustrative enough. With respect to epic traditions, particularly relevant to the present discussion are two episodes in the

69 sa kumbhakarṇam surasainyamardanam mahatsu yuddheșv aparājitaśramam/nananda hatvā bharatāgrajo raṇe mahāsuraṃ vrọtram ivāmarādhipaḥ // (Rāmāyaṇa, Yuddhakāṇụa, 55.129; Goldman, Sutherland Goldman and van Nooten 2010, vol. 6, part. 1: 299).

70 Indra's status in the Buddhist cosmological system is notably described in the Samyuttanikāya (1.11.2.2). Indra (here Sakka) is described as: sakko bhikave devānam indo devānaṃ Tāvatiṃsānam issariyādhipaccanaṃ rajjaṃ kāresi tasmā devānam indo ti vuccati [...]. "Sakka the king of gods rules over the gods of the thirty-three in great splendour so he is called king of gods" (Bhikkhu Bodhi 2000, 229). In the Buddhist context, Indra is most frequently referred to as Sakka or Śakra (strong, powerful, mighty), an epithet which is occurring many times in the Vedas mainly to qualify Indra. Despite the differences between the Vedic Indra and the Buddhist Śakra, the characteristics which they share make the two entities inseparable.

71 See for instance the Kulāvaka-jātaka (Fausbøll 1962-1964, 1.31; Cowell and Chalmers 1957, 1: 76-83), Kakkatā-jātaka (Fausbøll 1962-1964, 3.267; Cowell and Chalmers 1957, 2: 235-237) the Āsańka-jātaka (Fausbøll 1962-1964, 3.380; Cowell and Chalmers 1957, 3: 161-164), the Tacchasūrata-jātaka (Fausbøll 1962-1964, 14.492; Cowell and Chalmers 1957, 4: 216-222). 
Mahābhārata where Skanda-Kārttikeya is asked, in fact once by Indra himself, to become or replace Indra who "protects the group of gods."72

The circumstances which lead Skanda-Kārttikeya to take the leadership of the army of gods differ to varying degrees between sources. Accounts found in the Mahābhārata, the Rāmāyaṇa and the Kumārasaṃbhava, to mention the most verbose on the topic, agree that Skanda-Kārttikeya was engendered in order to take over a role forsaken by another god but often diverge on the identity of the predecessor (usually Indra or Śiva) ${ }^{73}$ and on the child's lineage (Agni, Rudra-Śiva, Svāhā, Gañga, the Kṛttikās and Pārvatī). ${ }^{74}$ As for the actual task with which the god is invested, this is explicitly stated by Skanda-Kārttikeya as he answers Indra's request: “Consecrate me to the generalship for the purpose of protecting cows and Brahmins, and for the success of the gods and the destruction of Dānavas."75 The consecration of Skanda-Kārttikeya as senāpati is followed by a glorified portrayal of the military god in armour and weaponry. ${ }^{76}$ Skanda-Kārttikeya's slaying of

72 Skanda-Kārttikeya is himself not certain what this task implies and asks: kim indraḥ sarvalokānāṃ karotīha tapodhanāḥ/katham devagaṇāṃś caiva pāti nityam sureśvarah // (Mahābhārata, 3.218.8). The passage is translated by Mann $(2012,59)$ as follows: "Great ascetics, what does the Indra of the worlds do? Tell me, how the lord of all the gods always protect the group of the gods?"

73 In the Rāmāyaṇa (1.36) and the Kumārasambhava (Canto 2.1) for instance, we are told that the assembly of gods approached Brahma and requested a leader for their army while Śiva was engaged in austerities.

74 For a discussion on the various accounts of Skanda-Kārttikeya's origin see Mann 2012, part. 62-73 and 79-101 and 182-187 and 199-201.

75 dānavānām vināśāya devānām arthasiddhaye/gobrāhmaṇasya trānārtham senāpatye ‘bhiṣiñca mām // (Mahābhārata 3.218.22; Mann 2012, 60).

76 araje vāsasī rakte vasānaḥ pāvakātmajaḥ/bhāti dīptavapuḥ śrīmān raktābhrābhyām ivāṃśumān // kukkuțaś cāgninā dattas tasya ketur alaṃkṛtaḥ/rathe samucchrito bhāti kālāgnir iva lohitah // [...] viveśa kavacam cāsya śarīraṃ sahajaṃ tatạ̣/yudhyamānasya dehasya prādurbhavati tat sadā//śaktir varma balaṃ tejạ̣ kāntatvaṃ satyam akṣatị̣ / brahmaṇyatvam asaṃmoho bhaktānām parirakṣaṇam // nikrntanam ca śatrūnāṃ lokānāṃ cābhirakṣaṇam/skandena saha jātāni sarvāṇy eva janādhipa // (Mahābhārata 
Tāraka is undoubtedly the most famous of his achievements. The demon who torments the gods and endangers Brahmanic values is alternatively Skanda-Kārttikeya's first mission (Mahābhārata 13.86.26-27) or the very reason why the boy was engendered and born. ${ }^{77}$ In quality of senāpati however, Skanda-Kārttikeya confronts various demons in battle, among which the demon named Mahișa (Mahābhārata 3.221.60), whose defeat is normally attributed to Dürga. The reason why this is worth noting is that this somewhat minor episode is only rarely illustrated and that one of the few depictions comes from Mohammad Zai and is now preserved in the Department of Archaeology Museums at Peshawar (Vitali et. al. 2008, nos. 111, 132 and 160).

As for Pharro, the term has been identified as the Bactrian form of the Avestan $\chi^{v}$ arznah- and of its Iranian cognates (hvarnah in Old Iranian and farrah in Middle Persian) and is generally taken to refer to the personification

3.218.31-36). The passage is translated by Mann (2012, 60-61) as follows: "The son of Pāvakā [Agni] was clothed in a pair of red dustless clothes. His blazing and glorious body shone like the sun covered in two red clouds. The cock, which was given to him by Agni and which adorned his banner and which was raised over his chariot, shone red like the Doomsday fire. His armour entered his body, which was produced at his birth; it always becomes manifest when the god is firing. Spear, armour, strength, splendour, beauty, truth, invulnerability, Brahminic faith, lack of confusion, protection of worshippers, and the destruction of enemies, and the protection of all the worlds were all born with Skanda, O King." The consecration is only briefly alluded to in the Rāmāyana (1.36.29-30): grhītvā kṣiram ekāhnā sukumāra vapus tadā/ajayat svena vīryeṇa daityasainyagaṇān vibhuḥ//surasenāgaṇapatịn tatas tam amaladyutim/abhyașiñcan suragaṇāh sametyāgnipurogamāh // translated by Goldman $(2007,195)$ as: "After that lord had drunk their milk for but a single day, he conquered the hosts of daitya warriors through his own might, through his form was that of a tender boy (29). Therefore the hosts of the gods assembled and making Agni, the god of fire, their spokesman, consecrated him whose radiance was unblemished, as commander of the hosts of the gods (30)."

77 Kumārasambhava, Canto 2.51. The passage reads: “O Almighty God, we, therefore desire to create a leader to destroy him (Tāraka), as those desirous of salvation wish to amass religious virtue, which cuts off the fetters of Karman." (Kale 1981, 176). 
of the Zoroastrian concept of $\chi^{v}$ aranah- ${ }^{78}$ Much of the knowledge about $\chi^{v}$ aranah- derives from the Yašt, the section of the Zoroastrian Avesta containing hymns dedicated to divinities or divine concepts. These, notably Yašt 10, 17 and 19 have been thoroughly reviewed by Bailey who highlighted the changing nature of the concept showing that it evolved:

from the primary meaning 'the things obtained or desired' by way of 'good things' and 'riches' to the 'good fortune' assured by riches to the possessor of hvarnah, and thence to 'Fortune', a divine (mēnōkïk) hypostasis, and a force bestowing 'good fortune' including all success and victory. It is a creation of Ahura Mazdā and therefore an object of yasna, reverent worship [...]. (Bailey 1971, 29)

In the context of the Kushan era, the existence of a cult to Pharro is essentially attested by the numismatic types issued by Kanișka I and Huvișka I and scholarship refers to him as a personification of royal good fortune (Rosenfield 1967, 96). As observed, the feathered headdress is a characteristic of Pharro and is borrowed from that of Hermes-Mercury to whom he is equated in quality of herald of gods and god of fortune. More generally, the bird imagery may be interpreted as an emblem of legitimate kingship, received from Ahura Mazdā. ${ }^{79}$

78 The matter, however, is more complicated than that as both the concept of $\chi^{v}$ aranah-and its etymology are themselves subject to debate. For a summary on the topic see Lubotsky $1998,480$.

79 On the symbolism of bird imagery within the Iranian context see Curtis 2007; Rosenfield 1967, 95-93 and Granoff 1970, 163. With respect to Kushan coinage, bird imagery is common to representations Orlagno (Avestan: Verethraghna) on Kushan coinage, although taking a different form. The god of war or the god of Iranian in arms is shown with a bird in his headdress. 
Concerning Hermes, it is evidently not the qualities of a leader or of a military hero that are to be listed here. Nevertheless, a passage of the Iliad endows the Greek god with a mission comparable to that of Pharro's symbolism. In this passage, Hermes is acting as a link between Zeus and Pelops in the transmission of the Atreids' scepter to Agamemnon, "to bear, to rule over many islands and all of Argos." (Iliad 2.100-108; Powell $2014,65)$ More directly connected to the protective function highlighted for others gods is Hermes's quality of guide. This quality is conveyed in various episodes and epithets ${ }^{80}$ but is elaborate in the lliad. Hermes is the pompos, the guide, sent by Zeus to lead Priam to the corpse of his dead son Hector which is lying beside the Achilles's ship. The god, who conducts the old man through the night, is described not only as a guide, but as a protector and a helper:

But as your guide I would go even to famous Argos, attending you kindly either in a swift ship or on foot. Nor would any man scorn me as a guide and attack us $^{81}$

Thus Hermes the helper spoke. Then he leaped upon the chariot and swiftly he took hold of the whip and took the reins in his hands. (Iliad 24.427-433; Powell 2014, 557)

Hermes auspicious qualities are further celebrated by Priam:

80 For an overview the episodes portraying Hermes as a guide (either of travellers, of souls, or cattle) see Siebert 1990, 286-287.

81 A few lines above, Hermes himself states: "I will defend you against anyone else" (Iliad 24.364; Powell 2014, 556). 
Surely, some god has stretched forth his hand over me, who has sent a wayfarer such as you to meet me. You are a bringer of good fortune, one wonderful in form and beauty. (Iliad 24.366-371; Powell 2014, 556)

Let us close this indicative overview of some of the characteristics ascribed to Buddhist, Brahmanical, Zoroastrian and Classical gods and reconsider the hypothesis suggested at the outset that multiple meanings are attached to the figure with a bow. The preceding overview highlights a system of values shared by the divinities and centered on the function of protection. These functional affinities are, as previously observed, paralleled on the visual level by certain iconographic affinities. If we ignore the Buddhist affiliation of the relief, from the strictly functional point of view each of the gods listed has the ability or the 'credentials' to both guide and protect the prince in his escape. Likewise, from a purely formal point of view, given that the fashions described above are also characteristic of representations of Pāñcika, Skanda-Kārttikeya, Pharro and Hermes found in the region, nothing prevents us from recognizing another Buddhist figure or the Brahmanical, Zoroastrian and Classical gods. Consequently, in principle, there are no reasons that would speak against attaching additional meanings to the fashions used to portray Vaiśravana-Kubera and Indra.

Two problems arise, however. Firstly, the attributes carried by the protagonist on the Gandhāran reliefs are inconsistent with the preferential attributes found in representations of the above-mentioned gods, whether in Gandhāra or elsewhere. As can be seen on figures 25 and 26, Pāñcika usually holds a spear and a purse or a cup. Statues of Skanda-Kārttikeya from Gandhāra (fig. 31) depict him with a cock and a spear. The last attribute is also that of Pharro who can also carry a sword (fig. 28) or the 
kerykeion (fig. 24), which he takes from Hermes. ${ }^{82}$ As a matter of fact, Indra himself is usually credited with the vajrā. As for Vaiśravaṇa-Kubera, it is only in the context of the great departure that he is credited with some weapons. Later depictions of the god ${ }^{83}$, however, show him with a spear and a miniature stūpa. ${ }^{84}$ Secondly, one cannot ignore that the context in which the figure with a bow appears is a Buddhist one. But would the introduction of a non-Buddhist god beside the Bodhisattva really constitute an oddity to the Gandhāran viewer?

\section{Concluding remarks}

By way of conclusion, let us briefly consider the illustrations of the great departure in their broader context of production, namely the multi-cultural and multi-religious context of the Kushan era. In this respect, three sets of documents can be mentioned, starting with the representation of two divinities who are frequently depicted on reliefs of the great departure: the yakșa Vajrapāṇi and the nāgaradevatā (the city goddess) of Kapilavastu. These two examples, undoubtedly the most commented

82 As already indicated, Hermes is shown in full-length, holding the kerykeion on the coinage of Azes II. See note 54.

83 For examples of a later representations of the guardian of the northern quarter of the universe from Dunhuang and attributed to the eighth and ninth centuries see Anderl (forthcoming).

84 One could probably find in written or visual traditions justifications for the unusual attribution of the bow and arrow. The rainbow is for instance referred to as Indra's bow (Indra-dhanús) in the Atharvaveda (15.1.6). The Rāmāyana reports that the arrow Lakșmana uses to defeat the demon "had been granted to him in a dream by immeasurable Kubera himself" (Yuddhakāṇḍa, 78.14-15; Goldman, Sutherland Goldman, van Nooten 2010, vol. 6, part 1: 381). As for Skanda-Kārttikeya, Gandhāran depictions of the god do show him with the arrow across his chest. Nevertheless, it must be admitted that these weapons are not emblematic of either visual or written portrayals of these gods. 
upon, are characteristic of the tendency of Gandhāran artists to draw upon a pool of iconographic traditions to construct the iconography of the Buddhist figure. Their iconographic prototypes derive from or show affinities with depictions of Heracles on the one hand and with several goddesses: the Greek Tyche, the Roman Fortuna, the Iranian Ardoxšo and the Indian yakșī. The reasons why Vajrapāṇi and the nāgaradevatā have been equated to Classical, Zoroastrian and more generally Indic divinities have been discussed by several scholars. These have demonstrated that the iconographic borrowings or similarities rely on symbolic equivalences associated to terrestrial power concerning Vajrapāṇi ${ }^{85}$, fertility and city protection with regard to the nāgaradevatā (Foucher 1913, 123-138; Gnoli 1953, 29-37; Fischer 1987, 61-65). Whether or not the original meanings of the Classical, Zoroastrian or Indic divinities were understandable to viewers of the reliefs is difficult to tell but the following epigraphic documents might shed some light on the question.

The first document is a silver phiale published by $\mathrm{H}$. Falk, dated to the fourth-third century b.c.e. on the basis of toreutic parallels and bearing two inscriptions, one in Greek and one in Gāndhārī. Both are commemorating the gift of a Greek official (a meridarchēs) to redeem a boon granted by a god. ${ }^{86}$ The god is named Chaos in the inscription in Greek and Boa in the Gāndhārī version. While Chaos is not attested as a god in Greek literature

85 The reasons why Vajrapāni's iconography feeds upon representations of Heracles predominantly, but also of Alexander the Great, Pan or Serapis, are one of the most debated subjects in the field of Gandhāran Buddhist art. It is beyond the scope of this paper to review all the hypotheses formulated. For the main propositions see Foucher 1905-1951, 1: 544-543; Lamotte 1966, 113-159; Santoro 1979, 293-343; Flood 1989, 17 27; Santoro 1992, 269-309; Giuliano 2001, 247-298; Quagliotti 2002-2003, 16-30; Tanabe 2004, 111-137; Zin 2005, 73-88; Filigenzi 2006, 271-285.

86 Falk 2009, 26-28. The inscription in reads "Kalliphōn, the Meridarchēs, after a vow dedicated (it) to *Chaos." and "By Kalliphōn, the Meridarchēs, after a promise, (this) was repaid for Boa." 
(but rather for a concept), the name Boa can be identified with the Vedic Bhava, a form of Rudra. Bhava is regarded as "a name of the uncivilized primeval deity" (Falk 2009, 28) to which, admittedly, the Greek equivalent used by the meridarchēs, "Chaos," does justice. ${ }^{87}$ The remaining inscriptions come from the Buddhist monastic complex of Zar Dherī, located on the right bank of the Siran River in northeast Pakistan. They are carved on the back of some of the stone reliefs which were found on the site and record the names of some of the donors and sculptors involved in the sponsorship and construction of the complex. ${ }^{88}$ Their names, "Boïrea of the Pharas," "Prianadi," "Cavaliaoḍa of the Vavaṇaas" and "Hariśava," are Iranian (IndoScythian) and Indian in origin and give a glimpse of the multi-ethnic milieu of Zar Dherī. Worth noting is the fact that the name "Hariśava," probably that of a sculptor, is carved at the back of a stone relief which was once attached on the base of the Buddhist stūpa and which shows a groupportrait of Olympian gods banqueting (Koizumi 2011, 309 pl. 216).

What are the implications of this in the context of the great departure scene? In light of the cultural and religious entanglement illustrated by visual and epigraphic documents, the following proposition is submitted for evaluation. The diversity of the motifs used to represent the guiding figure on Gandhāran reliefs and which contrasts with ancient illustrations of the event of the Indian-subcontinent, can be accounted for by the rich pool of religious and pictorial traditions which came into contact in the Gandhāran

87 The Rabatak inscription attributed to Kaniška I provides another good example of an explicit assimilation between two gods from different religious traditions: SkandaKārttikeya and Sraoša. Incidentally, it shows that one god may be associated to more than one divinity. While the main inscription provides a list of Zoroastrian gods, a short interlinear inscription placed between the Zoroastrian Nana and Sraoša reads: "who in Indian is called Mahāsena and is called Viśakha" (Sims-Williams 2004, 56).

88 The study of the epigraphic corpus from Zar Dherī has been conducted by R. Salomon and is published in the archaeological report of the site (Salomon 2011, 381-391). 
region. Several divinities may be recognized under the five main guises depicted, making their bearer ambiguous or rather polyvalent. As shown, the Buddhist, Zoroastrian, Brahmanical and Classical gods portrayed with these fashions in Gandhāra all share the charges of a protector and a guide. These functions are consistent with the role played by several devas in some written and visual accounts of the great departure. In the Gandhāran context, these functions are indicated by the position of the figure leading the cortege, the heavy armor and additionally signaled by the bow and arrow which could for instance, be interpreted as generic and unifying attributes for gods belonging to different pantheons.

In view of the common characteristics and existing logic which parallel the iconographic affinities between the deities of the Buddhist, Brahmanical, Zoroastrian and Classical pantheons, one may suspect that the multiple intenders of the motif included into the Gandhāran relief were not accidental. In other words, those individuals who selected from a repertoire of pictorial models to construct the portrayal of the figure with a bow are likely to have been aware of the functional links existing between the deities and may have hoped that the unique iconography created would resonate with many sectors of the Gandhāran population. Given the multicultural and multi-religious context in which Gandhāran imageries were produce, the possibility that the figure with a bow may evoke deities other than, or additional to, Vaiśravaṇa-Kubera and Indra to some viewers, is at least worth considering.

\section{Acknowledgments}

I would like to thank Alexandre Astier (University of Paris IV-Sorbonne), Prof. Osmund Bopearachchi (CNRS, Paris), Dr. Götz König (Free University, 
Berlin), Prof. Jörg Plassen (Ruhr Universty Bochum) and the reviewers for their comments and invaluable help in improving this paper. My thanks also go to Martina Stoye (Museum for Asian Art, Berlin) for the stimulating views she was willing to share on the topic. I am also grateful to Dr. Christoph Anderl (University of Ghent) and Dr. Licia Di Giacinto (Ruhr University Bochum) for their observations on Chinese accounts of the great departure and to Dr. Giovanni Ciotti (University of Hamburg) for his comments on quotations of Sanskrit sources. Any errors are the sole responsibility of the author. Thanks are also due to Prof. K. Tanabe (Chuo University, Tokyo) and Dr. Ken Hirayama for their permission to reproduce the pieces from the Hirayama Ikuo Silk Road Museum.

\section{Reference List}

Ackermann, Hans Christoph. 1975. Narrative Stone Reliefs from Gandhara in the Victoria and Albert Museum in London. Catalogue and Attempt at a Stylistic History. Rome: IsMEO.

Anderl, Christoph. Forthcoming. Aspects of Dūnhuáng - Khotan relations as reflected in Buddhist Text and Image.

Agrawala, Prithvi Kumar. 1967. Skanda-Karttikeya. A study in the origin and the development. Varanasi: Banaras Hindu University.

Allon, Mark. 2008. "Recent Discoveries of Buddhist Manuscripts from Afghanistan and Pakistan and Their Significance." In Art, Architecture and Religion along the Silk Roads. Silk Road Studies. Vol. 12, edited by Ken Parry, 153-178. Turnhout: Brepols.

Astier, Alexandre. 2014. Recherches sur l'iconographie de Kubera. Doctoral Dissertation in Art History. Paris 4, Sorbonne University [unpublished]. 
Bachhofer, Ludwig. 1937. "Pancika und Hāritī. Faro und Ardoxso." Ostasiatische Zeitschrift 23: 6-15.

Bailey, Harold Walter. 1971. Zoroastrian Problems in the Ninth-Century Books. Oxford: Clarendon Press.

Bareau, André. 1963-1995. Recherches sur la biographie du Buddha dans les "Sūtrapițaka" et les "Vinayapițaka" anciens. 3 vols. Paris: École Française d'Extrême-Orient.

Barua, Benimadhab. 1931-1934. Gayā and Buddha-Gayā. 2 Vols. Calcutta: Stis Seal.

Beal, Samuel, trans. 1875. Fóběn xíng jíjing, The romantic legend of Sâkya Buddha. London: Trübner \& co.

Beal, Samuel, trans. 1883. The Fo-Sho-Hing-Tsan-King, A Life of Buddha by Asvaghosha Bodhisattva, translated from Sanskrit into Chinese by Dharmaraksha, A. D. 420. Oxford: Clarendon Press.

Bedeker, V. M. 1969. "Kubera in Sanskrit Literature, with Special Reference to the Mahābhārata (From an Earth-Spirit to a God)." Journal of the Ganganatha Jha Research Institute 25: 425-451.

Bhattacharya, Gourishwar. 1987. “Dāna-deyadharma: Donation in early Buddhist records (in Brāhmī)." In Investigating Indian art, edited by Marianne Yaldiz and Wiebke Lobo, 39-60. Berlin: Staatlicher Museen Preussischer Kulturbesitz.

Bhattacharyya, Dinesh Chandra. 2002. A Catalogue of the Archaeological Relics in the Museum of the Varendra Research Society. Rajshah: The Varendra Research Society.

Bhikkhu Bodhi, trans. 2000. The Connected Discourses of the Buddha. A Translation of the Samyutta Nikāya. Translated from the Pāli. Boston: Wisdom Publication. 
Bhikku Ñāṇamoli and Bhikkhu Bodhi, trans. 1995. The Middle Length Discourses of the Buddha. A Translation of the Majjhima Nikāya. Translated from the Pāli. Boston: Wisdom Publication.

Bopearachchi, Osmund, Christian Landes, and Christine Sachs, eds. 2003. De I'Indus à l'Oxus, Archéologie de l'Asie Centrale. Lattes: Imago.

Bopearachchi, Osmund. 1991. Monnaies gréco-bactriennes et indogrecques: catalogue raisonné (Bibliothèque nationale, Cabinet des médailles et des antiques). Paris: Bibliothèque Nationale.

Bopearachchi, Osmund. 2003. An Indo-Greek and Indo-Scythian Coin Hoard from Bara (Pakistan). Seattle: Amir Nawaz Khan.

Bruchmann, Karl Friedrich. H. 1893. Epitheta deorum quae apud poetas Graecos leguntur. Leipzig: B. G. Teubner.

Buddhacarita = Cowell, E. B. ed. and trans. (1894) 1977. The BuddhaKarita or Life of Buddha by Asvaghosha. New Delhi: Cosmo.

Burgess, James. 1900. "The Gandhara Sculptures: some recent acquisitions." Journal of Indian Art and Industry 8: 73-92.

Chatterjee, Asim Kumar. 1970. The Cult of Skanda-Kārttikeya in Ancient India. Calcutta: Punthi Pustak.

Coomaraswamy, Ananda Kentish. 1971. Yakșas, 2 Vols. Delhi: Munshiram Manoharlal.

Cowell, Edward and Robert Chalmers, trans. (1895-1907) 1957. The Jātaka or Stories of the Buddha's Former Births. 6 Vols. Cambridge: Pali Text Society.

Cribb, Joe, and Robert Bracey. 2011. Kushan Coins Catalogue. London: British Museum. 
Cunningham, Alexander. 1885. Archaeological Survey of India, Report for the year 1872-1873, Vol. 5. Calcutta: Office of the Superintendent of Government Printing.

Curtis, Vesta Sarkhosh. 2007. “Religious Iconography on Ancient Iranian Coin." In After Alexander: Central Asia before Islam. Proceedings of the British Academy, 133, edited by Joe Cribb and Goergina Herrmann, 413-434. Oxford: Oxford University Press.

Dagens, Bruno. 1964. "Fragments de sculpture inédits." In Monuments Préislamiques d'Afghanistan. Mémoires de la Délégation Archéologique Française en Afghanistan. Vol. 19, edited by Bruno Dagens, Marc Le Berre and Daniel Schlumberger, 11-39. Paris: de Boccard.

de Foucaux, Philippe Édouard, trans. 1988. Lalitavistara, L'histoire traditionnelle de la vie du Bouddha Çakyamuni, traduit du Sanskrit. Paris: Les Deux Océans.

de Jong, Jan Willem. 1954. "L'épisode d'Asita dans le Lalitavistara." In Asiatica: Festschrift Friedrich Weller; zum 65. Geburstag gewidmet von seinen Freuden, Kollegen und Schülern, edited by Johannes Schubert and Ulrich Schneider, 312-325. Leipzig: Harrasowitz.

Dīgha-nikāya = Estlin Carpenter, J. ed. (1911) 2006. The Dīgha-Nikāya. Vol. 3. Lancaster: Pali Text Society.

Divyāvadāna = Vaidya, P.L. ed. 1959. Divyavadana. Buddhist Sanskrit Texts Series 20. Darbhanga: Mithila Institute.

Dobbins, K. Walton. 1973. "Gandharan art from stratified excavations." East and West 23: 279-294. 
Dutoit, Julius, trans. 1921. Nidānakathā. Jātakam. Das Buch des Erzählungen aus früheren Existenzen Buddhas 7. München: Oskar Schloss Verlag.

Eggeling Julius, trans. 1882. The Śatapatha Brahmana according to the Mādhyandina School. 5 Vols. Oxford: Clarendon Press.

Errington, Elizabeth. 1987. The Western Discovery of the Art of Gandhāra and the Finds of Jamālgarhī. Doctoral dissertation, School of Oriental and African Studies, London [unpublished].

Faccenna, Domenico, and Anna Filigenzi. 2007. Repertorio terminologico per la schedatura delle sculture dell'arte gandharica-Sulla base dei materiali provenienti dagli scavi della Missione Archeologica Italiana dell'IsIAO nello Swat, Pakistan. Rome: IsIAO.

Faccenna, Domenico. 1962. Reports on the Campaigns 1956-1958 in Swat (Pakistan). Mingora: Site of Butkara l; Sculptures from the Sacred Area of Butkara I (Swat, Pakistan), Part 2, Plates I-CCCXXXV and Plates CCCXXXVI-DCLXXV. IsMEO Reports and Memoirs 1-2. Rome: IsMEO.

Faccenna, Domenico. 2001. Il fregio figurato dello stupa principale nell'arte sacra buddhista di Saidu Sharif I (Swāt, Pakistan). IsIAO Reports and Memoirs 28. Rome: IsIAO.

Faccenna, Domenico. 2006. "Reconstruction of a Sculptural Complex in the Buddhist Sacred Area of Butkara I." East and West 56 (1-3): 177-194.

Falk, Harry. 2009. "Greek Style Dedication to an Indian God in Gandhāra." Indo-Asiatische Zeitschrift 13: 25-42. 
Filigenzi, Anna. 2006. "Ananda and Vajrapāṇi in Gandhāran Art." Gandhāran Buddhism: Archaeology, Art, Texts, edited by Pia Brancaccio and Kurt Behrendt, 271-285. Vancouver: University of British Columbia Press.

Fischer, Klaus. 1987. "Why has a Gandharan sculptor depicted the Nagaradevatā seminude in the Abhinișkramaṇa scene?" In Investigating Indian Art. Proceedings of a Symposium on the development of early Buddhist and Hindu iconography, held at the Museum of Indian Art Berlin in May 1986, edited by Marianne Yaldiz and Wibke Lobo, 61-65. Berlin: Museum für Indische Kunst, Staatliche Museen Preussischer Kulturbesitz.

Flood, Finbarr Barry. 1989. "Herakles and the 'Perpetual Acolyte of the Buddha: Some Observations on the Iconography of Vajrapāṇi in Gandhāran Art." South Asian Studies 5: 17-27.

Foucher, Alfred. 1905-1951. L'art gréco-bouddhique du Gandhāra: étude sur les origines de l'influence classique dans l'art bouddhique de I'Inde et de l'Extrême-Orient, 3 Vols. Paris: E. Leroux.

Foucher, Alfred. 1913. "Les images indiennes de la fortune." Mémoires concernant l'Asie Centrale 1: 123-138.

Foucher, Alfred, and John Marshall (1982) 1983. The Monuments of Sāñchī. 3 Vols. Delhi: Swati Publications.

Francfort, Henri-Paul. 1979. Les palettes du Gandhāra. Mémoires de la Délégation Archéologique Française en Afghanistan 33. Paris: de Boccard.

Ghirshman, Roman. 1962. Iran, Parther und Sassaniden. München: Verlag C.H. Beck.

Ghurye, G.S. 1977. Indian Acculturation: Agyasta and Skanda. Bombay: Popular Prakashan. 
Giuliano, Laura. 2001. “On Vajrapurusa." East and West 51: 247-298.

Gnoli, Raniero. 1953. "The Tyche and the Dioscuri in Ancient Sculptures from the Valley of Swat." East and West 14: 29-37.

Göbl, Robert. 1984. System und Chronologie der Münzprägung des Kušānreiches. Wien: Verlag der Österreichischen Akademie der Wissenschaften

Goldman, Robert P., Sheldon I. Pollock, Rosalind Lefeber, and Sally J. Sutherland Goldman, trans. (1984-1996) 2007-2010. The Rāmāyaṇa of Vālmīki, an epic of Ancient India. 5 Vols. Delhi: Motilal Banarsidass.

Granoff, Phyllis. 1970. “Tobatsu Bishamon: Three Japanese Statues in the United States and an Outline of the Rise of This Cult in East Asia." East and West 20: 144-167.

Grenet, Frantz. 1995-1996. "Vaishravana in Sogdiana. About the origins of Bishamon-ten." Silk Road Art and Archaeology 4: 277-297.

Grenet, Frantz. 2006. "Iranian Gods in Hindu Garb: The Zoroastrian Pantheon of the Bactrians and Sogdians, Second-Eigth Centuries." Bulletin of the Asia Institute 20: 87-99.

Iliad $=$ Allen, Thomas William, ed. 1931. Homeri Ilias. 3 Vols. Oxonii: E typographeo Clrendoniano.

Ingholt, Harald. 1957. Gandharan Art in Pakistan. New York: Pantheon Books.

Jātaka = Fausbøll, Viggo, ed. (1877-1897) 1962-1964. The Jātaka, Together with its Commentary. 7 Vols. London: Pali Text Society. Jayawickrama, N. A., trans. (1990) 2002. The Story of Gotama Buddha. The Nidāna-kathā of the Jātakațțhakathā. Oxford: Pali Text Society. 
Johne, Isabelle. 2003. "Pāñcika oder Pharro?" Berliner Indologische Studien 15/16/17: 421-438.

Jones, John James, trans. (1949-1956) 2006-2007. The Mahāvastu. 3 Vols. Lancaster: Pali Text Society.

Klimburg-Salter, Deborah. 1981. "Vaisravana in North-West India." In Madhu, Recent Researches in Indian Archaeology and Art History, M. N. Deshplante Festschrift, edited by M. S. N. Rao, 253262. Delhi: Agam Kala Prakashan.

Klimburg-Salter, Deborah, ed. 1995. Die frühindische Skulptur von König Aśoka bis zur Guptazeit. Vienna and Milan: Skira.

Knox, Robert. 1992. Amaravati: Buddhist Sculptures from the Great Stupa. London: British Museum Press.

Konow, Sten. 1929. Corpus Inscriptionun Indicarum. Kharoshthī inscriptions: with the exception of those of Aśoka. Delhi: Archaeological Survey of India.

Kumārasambhava = Kale, M. R. ed. and trans. (1981) 2004. Kumārasambhava of Kālidāsa, Cantos I-VIII. Delhi: Motilal Banarsidass.

Kurita, Isao. 1988. Gandāra bijutsu ガンダーラ美術 [The Art of Gandhāra]. 2 Vols. Tokyo: Nigensha.

Kurita, Isao. 2003. A Revised and Enlarged Edition of Gandhāran Art. 2 Vols. Tokyo: Nigensha.

Lamotte, Étienne. 1966. Vajrapāni en Inde. Mélanges de Sinologie offerts à Mr. Paul Demiéville 1, 113-159. Paris: Presses Universitaires de France.

Lattimore R., trans. 1967. The Odyssey of Homer. New York: Harper \& Row. 
LIMC = Lexicon Iconographicum Mythologiae Classicae, 1981-1999, 16 Vols. Zürich: Artemis \& Winkler Verlag.

Lobo, Wiebke. 1983. “Der Bogenträger in den Weltluft-Darstellungen der Gandhara-Reliefs." Zeitschrift der Deutschen Morgenländischen Gesellschaft, Suppl. 6: 430-437.

Longhurst, Albert Henry. 1938. The Buddhist Antiquities of Nāgārjunakoṇda. Memoirs of the Archaeological Survey of India 54. Delhi: Manager of Publications.

Lubotsky, Alexander. 1998. "Avestan Xvarənah-: the etymology and concept." In Sprache und Kultur der Indogermanen. Akten der $X$. Fachtagung der Indogermanischen Gesellschaft, edited by Wolfgang Meid, 478-488. Innsbruck: Innsbrucker Beiträge zur Sprachwissenschaft.

Lüders, Heinrich. 1963. Bharhut Inscriptions. Corpus Inscriptorum Indicarum 2 (2). Ootacamund: Government Epigraphist for India.

Mahābhārata = Sukthankar V. S. and Belvalkar S. K. eds. 19271959. Mahābhārata. For the First Time Critically Edited. Poona: Bhandarkar Oriental Research Institute.

Mahāvastu = Faure Emmanuel and Boris Oguibénine, eds. 2003. Mahavastu-Avadana, basé sur l'édition d'Émile Senart en 3 volumes, 1882-1897. Paris.

Majjhima-nikāya = Chalmers Robert, ed. 1898. The Majjhima Nikāya. London: Pali Text Society.

Mann, Richard D. 2012. The Rise of Mahāsena. The Transformation of Skanda-Kārttikeya in North India from the Kușāna to Gupta Empires. Leiden: Brill.

Mitra, R. L., trans. 1998. The Lalitavistara, Memoirs of the Early Life of Sakya Sinha (Chs. 1-15). Delhi: Sri Satguru Publications. 
Miyaji, Akira, ed. 1998. Buddha, The Spread of Buddhist Art in Asia. Tokyo: NHK.

Mizuno, Seiichi, and Takayasu Higuchi. 1978. Thareli. Buddhist Sites in Pakistan surveyed in 1963-1967. Publication of the Kyoto University Scientific Mission to Iranian Plateau and Hindukush. Tokyo: Dōhōsha.

Modhey, S. G. 1971-1972. "God Kubera in the Rāmāyaṇa." Journal of the Oriental Institute 21: 299-306.

Monier-Williams, M. A. (1899) 1960. A Sanskrit-English Dictionary Etymologically and Philologically Arranged with Special Reference to Cognate Indo-European Languages. Oxford: Clarendon Press.

Olivelle, Patrick, trans. 2009. Life of the Buddha by Aśvaghoșa. New York: Clay Sanskrit Library.

Parimoo, Ratan. 1982. Life of Buddha in Indian Sculptures. Așța-mahāprathihārya. New Delhi: D. K. printworld.

Pons, Jessie. 2011. Inventaire et étude systématiques des sites et des sculptures bouddhiques du Gandhāra: ateliers, centres de production. Doctoral Dissertation in Art History. Paris 4, Sorbonne University [unpublished].

Poonacha, K. P. 2013. Excavations at Kanaganahalli (Sannati Dist. Gulbarga, Karnataka), Memoirs of the Archaeological survey of India 106. Delhi: Director General, Archaeological Survey of India.

Powell, Barry B., trans. 2014. The Iliad, Homer, Translation, Introduction, and Notes. Oxford and New York: Oxford University Press. 
Quagliotti, Anna Maria. 2002-2003. “A Gandhāran Heracles in the Museum für Indische Kunst." Indo-Asiatische Zeitschrift 6/7: 1630.

Quagliotti, Anna Maria. 2003. "An Image in the Indian Museum with Some Considerations on the Tutelary Couples in Gandharan Art-A Catalogue of the Standing Images in the Kushan Period and Related Problems." Silk Road Art and Archaeology 9: 239296.

Quagliotti, Anna Maria. 2005. "The Guardians of the Buddha: from Gandhāra to Afghanistan." In Afghanistan, ancien carrefour entre l'est et l'ouest, Actes du Colloque International, edited by Osmund Bopearachchi and Marie-Françoise Boussac, 271-291. Turnout: Brepols.

Quagliotti, Anna Maria. 2008. "Deities integrated to Buddhism." In Gandhara-The Buddhist Heritage of Pakistan. Legends, Monasteries, and Paradise, edited by Christoph Vitali, Christian Luczanits, and Michael Jansen, 126-129. Mainz: Verlag Philipp von Zabern.

Rāmāyaṇa = Bhatt G. H. and U. P. Shah, eds. 1960-1975. The Vālmīki Rāmāyaṇa: Critical Edition. 7 Vols. Baroda: Oriental Institute.

Robert, Louis. 1968. "De Delphes à I'Oxus: inscriptions grecques nouvelles de la Bactriane." Comptes Rendus de l'Académie des Inscriptions et Belles Lettres 132: 442-454.

Rosen Stone, Elizabeth. 1994. The Buddhist Art of Nāgārjunakonḍa. Delhi: Motilal Banarsidass.

Rosenfield, John M. 1967. The Dynastic Arts of the Kushans. Berkeley: University of California Press. 
Rotman, Andy, trans. 2008. Divine Stories: Divyāvadana. Boston: Wisdom Publications.

Salomon, Richard. 2011. "Inscriptions from the Zar Dheri Excavation." In Zar Dheri, Archaeological Excavation of an Ancient Buddhist Site in Pakistan, edited by the Tokyo National Museum Mission to Pakistan, 381-391. Tokyo: Tokyo National Museum.

Saṃyutta-nikāya = Feer, Léon. ed. (1884) 2006. The Saṃyutta-Nikāya of the Sutta-pițaka. Lancaster: Pali Text Society.

Sańghabhedavastu = Gnoli, Raniero, ed. 1977-1978. The Gilgit Manuscript of the Sanghabhedavastu, Being the 17th and Last Section of the Vinaya of the Mūlasarvāstivādin. Serie Orientale Rome 49 (1). 2 Vols. Rome: Istituto Italiano per il Medio ed Estremo Oriente.

Santoro, Arcangela. 1979. “Il Vajrapāṇi Nell'Arte del Gandhāra: Ricerca Iconographica ed Interpretativa." Rivista degli Studi Orientali 53: 293-342.

Santoro, Arcangela. 1992. “Note di Iconographia Gandharica, V. Appunti sul Vajrapāṇi-Eracle." Rivista degli Studi Orientali 65: 269-309.

Satapathy, Chaturbhuja. 2002. Kubera: Origin and Development. New Delhi: Classical Publishing Company.

Sengupta, Anasua, and S. Dibakar Das. 1991. Gandhara holdings in the Indian Museum: A handlist. Calcutta: India Museum.

Seyrig, Henri. 1941. “Antiquités syriennes, 34. Sculptures palmyréniennes archaïques." Syria 22: 31-34.

Shahbazi, Alireza Shapur. 1974. “An Achaemenid Symbol. I. A Farewell to Fravahr and Ahuramazda." Archäologische Mitteilungen aus Iran 7: 135-144. 
Shahbazi, Alireza Shapur. 1980. “An Achaemenid Symbol II. Farnah '(God given) Fortune' symbolised." Archäologische Mitteilungen aus Iran 13: 119-147.

Shimada, Akira. 2006. "The Great Railing at Amaravati: An Architectural and Archaeological Reconstruction." Artibus Asiae 66 (1): 89141.

Shimada, Akira. 2012. "Formation of Andhran Buddhist Narrative: A Preliminary Survey." In Buddhist Narratives in Asia and Beyond, edited by Peter Skilling and Justin McDaniel, Vol.1, 17-36. Bangkok: Institute of Thai Studies, Chulalongkorn University.

Shimada, Akira. 2013. Early Buddhist Architecture in Context: The Great Stupa at Amaravati (ca. 300 BCE-300 CE). Leiden and Boston: Brill.

Sieber, Gérard. 1990. "Hermes." Lexicon Iconographicum Mythologiae Classicae, 5 (1), 285-387. Zürich: Artemis \& Winkler Verlag.

Sims-Williams, Nicholas. 2004. "The Bactrian inscription of Rabatak: A New Reading." Bulletin of the Asia Institute 18: 53-68.

Sinha, K. 17979. Kārttikeya in Indian Art and Literature. Delhi: Sundeep Prakashan.

Sivaramamurti, C. 1942. "Amaravati Sculptures in the Madras Government Museum." Bulletin of the Madras Government Museum. New Series, General Section, IV. Madras: The Director of Stationary and Printing.

Skjærvø, Prods Oktor. 1983. "Farnah: mot mède en vieux-perse." Bulletin de la Société Linguistique 78: 241-259.

Spooner, David Brain. 1908. Archaeological Survey of India Annual Report, Frontier Circle, 1907-1908. Peshawar: Government Printing. 
Spooner, David Brain. 1910. Archaeological Survey of India Annual Report, Frontier Circle, 1909-1910. Peshawar: Government Printing.

Srinivasan, Doris Meth. 1997-1998. "Skanda/Kārttikeya in the Early Art of the Northwest." Silk Road Art and Archaeology 5: 233-268.

Stančo, Ladislav. 2000. "Gandharan toilet tray with the image of scythoparthian king." Acta Universitatis Carolinae_Philologica 3: 137140.

Stein, Aurel. 1912. Archaeological Survey of India Annual Report, Frontier Circle, 1911-1912, Peshawar: Government Printing.

Sutherland, Gail Hinich. 1991. The Disguises of the Demon. The Development of the Yakșa in Hinduism and Buddhism. Albany: State University of New York Press.

Swati, Muhammad Farooq. 1997. "Special Features of the Buddhist Art in the Swat Valley." Āthāriyyāt 1: 1-60.

T. = Takakusu Junjirō 高楠順次郎 and Watanabe Kaikyoku 渡辺海旭, eds. 1924-1935. Taishō shinshū daizōkyō 大正新脩大藏經 [Revised Tripițaka Compiled during the Taishō Period]. Tokyo: Daizōkyōkai.

Taddei, Maurizio. 1966. "A problematical Toilet-tray from Udegram." East and West 16 (1-2): 89-93.

Tanabe, Katsumi. 1985. Gandāra no kifujin to keshōzara [Gandharan ladies and toilet-trays from Japanese collections]. Tokyo: Kodai Oriento Hakubutsukan.

Tanabe, Katsumi. 1993-1994. “Neither Mara nor Indra but Vaisravana in Scenes of the Great Departure of Prince Siddhartha." Silk Road Art and Archaeology 3: 157-186. 
Tanabe, Katsumi. 1997-1998. "The Goddess of Night in the Gandharan Great Departure Scene of Siddhartha." Silk Road Art and Archaeology 5: 213-233.

Tanabe, Katsumi. 1999. Bishamonten zo no tanjo: Shiruku Rodo no tozai bunka koryu (Rekishi bunka raiburari, 81). Tokyo: Yoshikawa Kobunkan.

Tanabe, Katsumi. 2000. "Kubera, Vaisravana, Indra and Brahma in Gandharan Great Departure scenes." In South Asian Archaeology 1997. Proceedings of the fourteenth international conference of the European Association of South Asian Archaeologists held in Rome, Palazzo Brancaccio, 7-14 July 1997, edited by Maurizio Taddei and Giuseppe De Marco, 1087-1100. Rome: IsIAO.

Tanabe, Katsumi. 2004. "Why is the Buddha Sākyamuni Accompanied by Hercules/Vajrapāṇi?: Farewell to Yakșa-theory." Bulletin of the Ancient Orient Museum 24: 111-137.

Tatelman, Joel, trans. 2005. The Heavenly Exploits: Buddhist Biographies from the Dĩvyavadāna, 2 Vols. New York: Clay Sanskrit Library and New York University Press.

Vaidya, P. L. ed. 1958. Lalita-Vistara. Buddhist Sanskrit Texts 1. Darbhanga: The Mithila Institute of Post-Graduate Studies and Research in Sanskrit Learning.

van Buitenen, J. A. B., trans. 1973-1978. The Mahābhāratha, 3 Vols. Chicago: University of Chicago Press.

Vergados, Athanassios, ed. \& trans. 2013. The Homeric Hymns to Hermes, introduction, text and commentary. Berlin: De Gruyter.

Vitali, Christoph, Christian Luczanits, and Michael Jansen, eds. 2008. Gandhara-The Buddhist Heritage of Pakistan. Legends, Monasteries, and Paradise. Mainz: Verlag Philipp von Zabern. 
Walshe, Maurice, trans. 1995. The Dïgha Nikāya. The Long Discourses of the Buddha. Boston: Wisdom Publication.

Wessels-Mevissen, Corinna. 2001. The Gods of the Directions in Ancient India. Origin and Early Development in Art and Literature (until c. 1000 A. D.). Berlin: Dietrich Reimer Verlag.

Whitney, William Dwight, trans. 1971. Atharvaveda Samphita. 2 Vols. Delhi: Motilal Banarsidass.

Willemen, Charles, trans. 2009. Buddhacarita, In Praise of the Buddha's Acts. Taishō Volume 4, Number 192. Berkeley: Numata Center for Buddhist Translation and Research.

Winternitz, Moriz. 1913. Geschichte der indischen Litteratur. 3 Vols. Leipzig: C. F. Amelang Leipzig.

Yoshihide, Koizumi. 2011. "Stone Sculptures." In Zar Dheri, Archaeological Excavation of an Ancient Buddhist Site in Pakistan, edited by the Tokyo National Museum Mission to Pakistan, 297-320. Tokyo: Tokyo National Museum.

Zin, Monika. 2005. "Vajrapāṇi in the Narrative Reliefs." In Migration, Trade and Peoples, edited by Christine Fröhlich, 73-88. London: The British Association for South Asian Studies.

Zwalf, Wladimir. 1996. A Catalogue of the Gandhāran Sculpture in the British Museum. London: The British Museum. 